
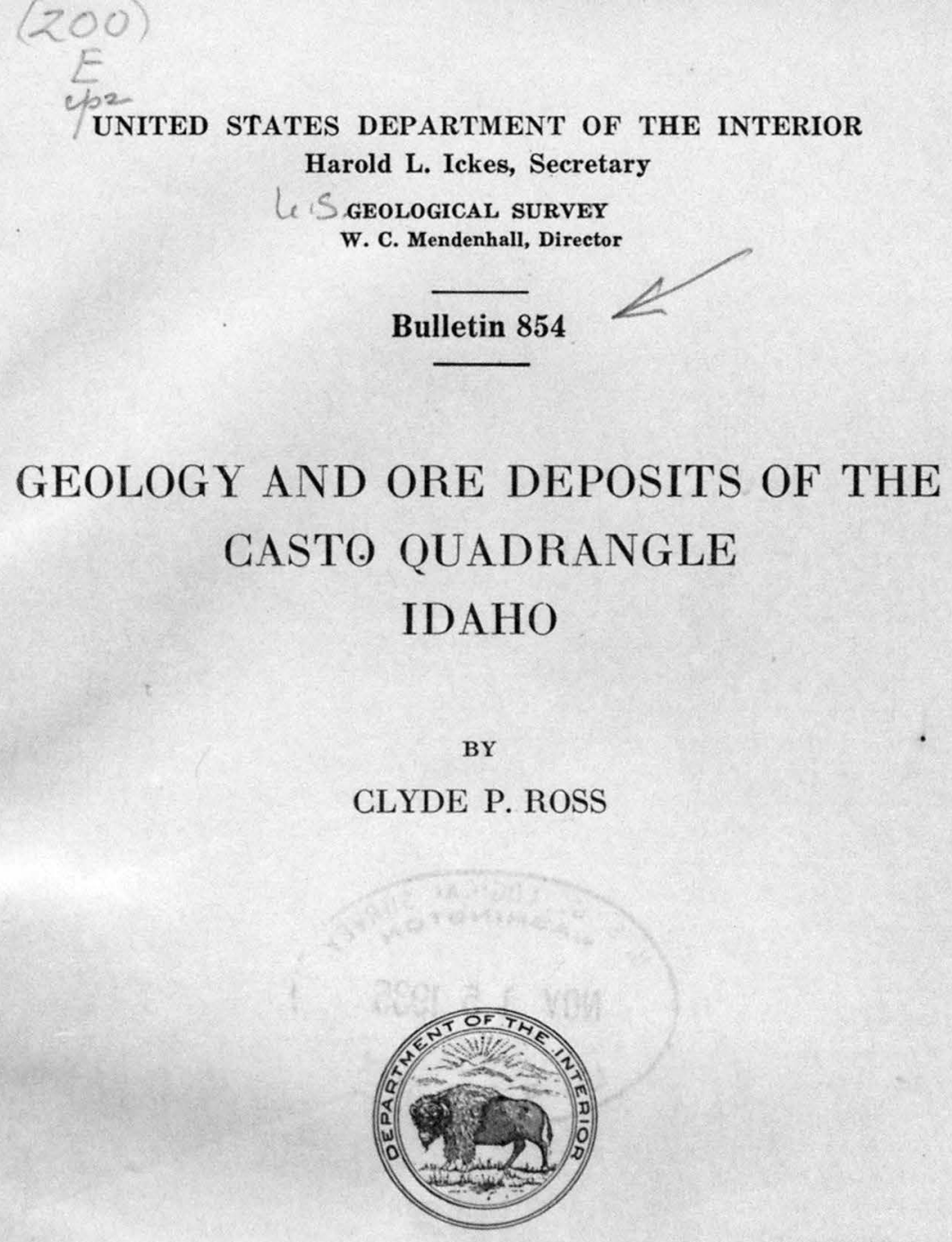

Bulletin 854

\author{
BY \\ CLYDE P. ROSS
}

$104346^{2}$

UNITED STATES

GOVERNMENT PRINTING OFFICE

WASHINGTON : 1934 


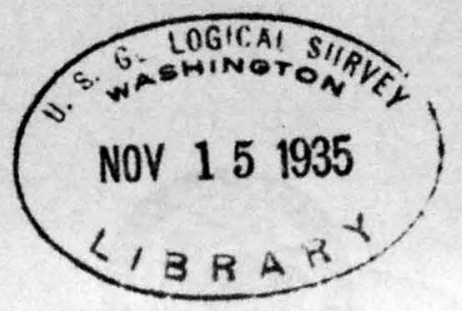




\section{CONTENTS}

Page

Abstract

Introduction

Location and means of access.... 1

Purpose and scope of the report

Acknowledgments........ 3

Geography _...

Topography .

Position

Relief

Drainage

Nomenclature of streams

Climate

Population _.

Industries_...

Ranching

Mining _. 9

Fauna and flora

Mammals _...

Birds. . .

Fish

Flora

Stratigraphy

Major features...

Ancient sedimentary and igneous rocks_.

Belt series (Algonkian) near Yellowjacket_.

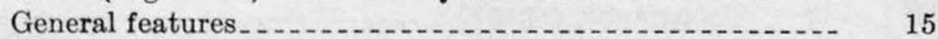

Yellowjacket formation _......

Quartzitic beds_................... 17

Calcareous beds

Hoodoo quartzite

Age of the sedimentary rocks near Yellowjacket_....... 19

Algonkian diabase................... 20

Distribution ................ 20

Character.........

Age

Algonkian and Paleozoic sedimentary rocks near Boyle ranch._- 21

General features._.

Schist_...

Dolomitic limestone.

Marble _.

Banded hornfels_. . .

Quartzite .

Age

Dolomite marble near Short Creek

Black schist near Woodtick Creek _.

Scattered exposures _... 28

Casto voleanics (Permian?) 28

Distribution............ 28

Topographic expression 
Stratigraphy-Continued.

Casto volcanics (Permian?)-Continued.

General character.

Lava and tuff

Andesitic rocks

Rhyolitic rocks

Conglomerate

Limestone

Thickness and stratigraphic relations _........... 32

Age and correlation ...

Rocks related to the Idaho batholith (Mesozoic) _...

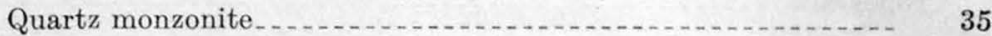

White quartz monzonite

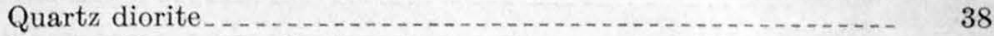

Porphyritic quartz diorite ................... 39

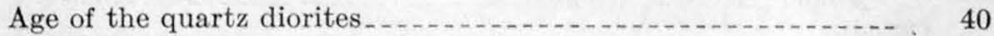

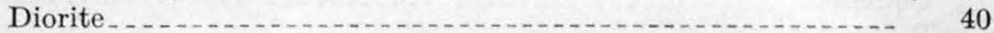

Dikes related to the Idaho batholith

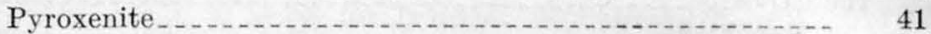

Kersantite in the Idaho batholith ................. 41

Aplite

Injection gneiss _...

Definition and distribution

Character........................... 42

Origin

Age of the Idaho batholith .

Tertiary volcanics (Oligocene)

Challis voleanies._. 46

Definition and distribution

Topographic expression _... 46

General character....... 46

Thickness _...... 47

Yankee Fork rhyolite member _.................. 52

Age of the Challis volcanics _... 53

Minor intrusive rocks related to the Challis volcanics_....... 54

Miocene intrusive rocks_._.

Pink granite

Hornblende granite and quartz monzonite

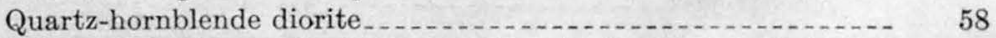

Relation of Miocene granite to Idaho batholith and injection gneiss

Porphyries related to the pink granite

White granite porphyry

Quartz-hornblende-biotite monzonite porphyry ............

Dacite porphyry.

Andesite porphyry

Pink granophyre

Coarse granophyre

Miocene (?) lamprophyre (kersantite) _.....................

Age and structural relations of the pink granite and related rocks.

Contact metamorphism, by W. H. Newhouse.

General features.

Minerals formed . . 69

Chemical changes..... 
Structure

Page

Structure in the old rocks

Folding

Overthrusting -

Normal faulting

Folds in the Casto volcanics.

Structural relations of the rocks of the Idaho batholith

Structure of Tertiary rocks.

Folding

Faulting .

Faults of northeast trend.

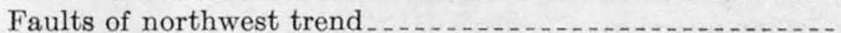

Structural relations of the Miocene granitic rocks

Geomorphology.

Old Tertiary erosion surface.

Late Tertiary erosion surface

Late Tertiary and early Quaternary events

Terraces and related features.

Glaciation

Distribution and extent.

Age of principal glaciation

Deposits of glacial and aqueoglacial origin

Possible older glaciation ........

Ridge-crest depressions . .

Landslides and slips

Summary _.

Geologic history

Pre-Cambrian time

Paleozoic time..... 94

Mesozoic time

Cenozoic time _.

Mineral deposits

Location _..........

Kinds of lodes . .

Shear zones with copper-lead-siderite ore (Mesozoic) $\ldots . \ldots . . . . .99$

Mineral deposits with fine ribbon-banded quartz (Miocene) _...... 101

Supergene processes . . 103

Placer deposits..._. 103

Opals _._.

Hot springs $\ldots 5$

Local descriptions

Yellowjacket district_..._. 107

Location and extent_...... 107

History and production ..... 107

Yellowjacket mine_.

General geology

Structural relations of the lode

Character of the ore

Columbia mine......... 112

Red Jacket prospect....

Copper Glance prospect..... 113

Ohio prospect

Continental prospect_.

Black Eagle mine 
Local descriptions-Continued.

Loon Creek district.

Location and extent

History

Placer deposits

Lost Packer mine

Location

Development_...

General geology

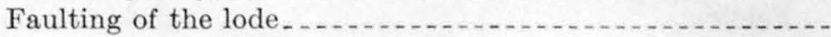

The ore

Oxidation and enrichment

Flux quarries.

Prospects near the head of Deer Creek_............... 124

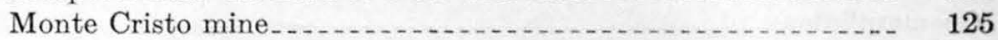

Scattered prospects in deposits probably of Mesozoic age

Mineralization near Sleeping Deer Mountain ............. 125

"Lost Cleveland mine"

Valentine prospect......

Parker Mountain district__._. 127

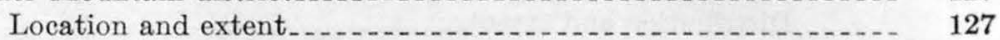

History _...

Parker Mountain mine

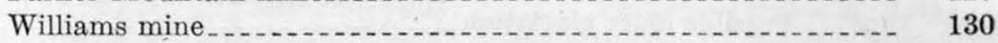

Minor deposits of Tertiary age 130

Mineralization near Hot Creek_..... 130

Mineralization on Horse Creek

Mineralization near Marble Creek _... 131

Stibnite-barite prospect_... 131

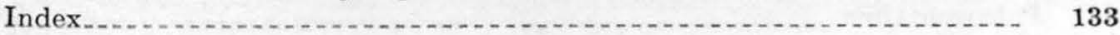

\section{ILLUSTRATIONS}

Page

Plate 1. Geologic map and sections of the Casto quadrangle...... In pocket

2. A, Lit-par-lit structure in gneiss; $B$, Contact between pink granite and injection gneiss

3. $A$, Brecciated gneiss; $B$, Contorted injection gneiss..........

4. A, Level-topped ridge on "high trail" near head of Spider Creek; $B$, Cirque lakes at head of West Fork of Camas Creek -

5. $A$, Ridge-crest depression on ridge near "high trail"; $B$, Undrained hollow at head of one fork of Grouse Creek .........

6. Plan and projection of Yellowjacket mine.

7. Geologic map and section of workings of Lost Packer mine....

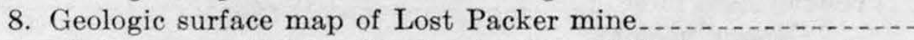

Figure 1. Index map of Idaho showing location of Casto quadrangle...

2. Gains and losses in contact metamorphism of dolomitic limestone

3. Sketch map of Copper Glance tunnel

4. Main workings of Lost Packer mine ........

5. Sketch map of Parker Mountain mine. 


\title{
GEOLOGY AND ORE DEPOSITS OF THE CASTO QUADRANGLE, IDAHO
}

\author{
By Clyde P. Ross
}

\begin{abstract}
The study of the Casto quadrangle was undertaken as the first item in a project to obtain more thorough knowledge of the general geology of southcentral Idaho on which to base study of the ore deposits of the region. The quadrangle contains fragmentary exposures of Algonkian and Paleozoic sedimentary rocks, extensive deposits of old volcanic strata, presumably Permian, not heretofore recognized in this part of Idaho, and a thick succession of Oligocene(?) lava and pyroclastic rocks. The Idaho batholith and its satellites extend into the quadrangle, and in addition there are large masses of Tertiary granitic rock, not previously distinguished in Idaho, and many Tertiary dikes, some of which are genetically associated with contact-metamorphic deposits. The area contains injection gneiss of complex origin, largely related to the Idaho batholith but in part resulting from injection by the Tertiary granitic rocks under relatively light load. Orogenic movements took place in Algonkian, Paleozoic, and Tertiary time. There is a summit peneplain or partial peneplain of Tertiary, perhaps Pliocene age, and the erosional history since its elevation has been complex.

The ore deposits include lodes and placers. The lodes are related to both the Idaho batholith and the Tertiary intrusive rocks and have yielded gold and copper ore of a total value of about $\$ 1,000,000$. Placers, largely formed in an interglacial interval, have yielded about an equal amount. There has been some prospecting but almost no production since 1916 .
\end{abstract}

\section{INTRODUCTION}

\section{LOCATION AND MEANS OF ACCESS}

The Casto quadrangle includes parts of the Challis, Salmon, Idaho, and Payette National Forests, in Custer, Lemhi, and Valley Counties, Idaho. It has an area of 850 square miles and is bounded by meridians $114^{\circ} 30^{\prime}$ and $115^{\circ}$ and parallels $44^{\circ} 30^{\prime}$ and $45^{\circ}$. (See fig. 1.) It includes the Yellowjacket, Loon Creek, and Parker Mountain mining districts and a few prospects outside of these districts.

The quadrangle is reached from Challis by three roads. One of these enters from the south and terminates at Ivers, 10 miles within 


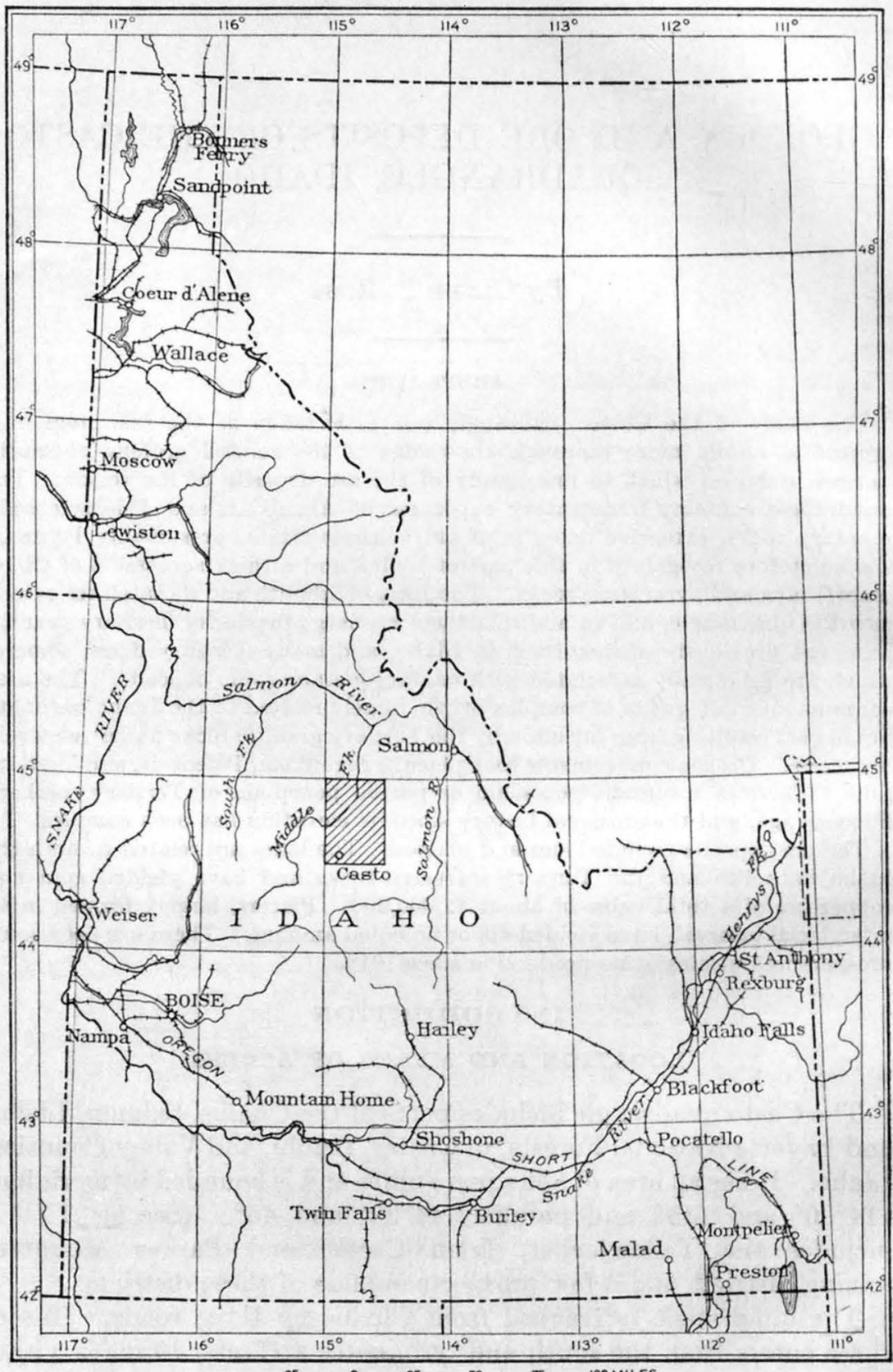

$25 \quad 25 \quad 50 \quad 75 \quad 1004$

FIGURE 1.-Index map of Idaho showing location of Casto quadrangle. 
the borders of the quadrangle and about 80 miles from Challis; another terminates at Meyers Cove, just outside the middle of the eastern boundary; and the third terminates at Yellowjacket, 2 miles inside the northeast corner of the quadrangle. Meyers Cove and Yellowjacket are each about 54 miles from Challis. There are no roads now (1930) passable to vehicles within the quadrangle other than those mentioned.

\section{PURPOSE AND SCOPE OF THE REPORT}

The broadest features of the geology of south-central Idaho are now known, but many details of importance in the study of the ore deposits of the region are still lacking. The study of the Casto quadrangle was undertaken with the hope of adding in some measure to the basic knowledge of the regional geology rather than to study any particular mineral deposits. Field work in the quadrangle consumed a total of $7 \frac{1}{2}$ months in the summers of 1925,1926 , and 1927 , and the quadrangle was mapped in as much detail as the scale of the topographic map permitted. In a few places obscurity of exposures, complexity of detail, and the limitations of time have necessitated some generalization. Incidentally, three mining districts within the quadrangle, each containing distinctive kinds of deposits, have been examined. Lack of adequate development in some mines and the inaccessibility of old workings in others hindered the work, but the data obtained suffice to give an understanding of the general features of the deposits.

\section{ACKNOWLEDGMENTS}

Hearty acknowledgment is here recorded for the aid rendered by the residents and national-forest officers in and near the quadrangle, who freely furnished much valuable information and by whose helpfulness the work was materially expedited. A list of those to whom thanks are due would include all the residents of the quadrangle and the supervisors and rangers of the national forests within its limits.

The writer was assisted in the field during the summer of 1925 by W. H. Newhouse, in 1926 by C. H. Behre, Jr., and in 1927 by D. M. Davidson. Each did his share in the geologic mapping and contributed valuable ideas and stimulating discussion of the problems encountered during the field work. James Bruce furnished and took charge of the pack train used during each of the three seasons, and his efficiency did much to facilitate the work. 


\title{
GEOGRAPHY
}

\section{TOPOGRAPHY}

\author{
POSITION
}

The Casto quadrangle lies in the east-central part of the Salmon River Mountains. As originally approved by the United States Geographic Board ${ }^{1}$ this name is assigned to the group of mountains in central Idaho lying in the big bend of the main Salmon River, west of Lemhi Range. A recent definition ${ }^{2}$ states that the mass extends westward as far as the South Fork of the Salmon River and includes the mountains forming the divide between the drainage basins of the Payette and Salmon Rivers from the north end of the Sawtooth Range to the head of the South Fork of the Salmon. This great mountain mass covers more than 7,300 square miles, broken only by narrow valleys, of which those of the South, Middle, and Yankee Forks of the Salmon River are much the largest. Variations in the character of the topography are not sufficiently definite to permit subdivision of the mountain mass into distinct ranges. Such local names as "Yellowjacket Mountains", recently approved by the Geographic Board, ${ }^{3}$ merely express the fact that a certain part of the mass is near some well-known place and are not applied to clean-cut topographic units. Such names, however, aid materially in descriptions of the region.

\section{RELIEF}

The Casto quadrangle is in one of the most rugged parts of the Salmon River Mountains. It is maturely and uniformly dissected. Valley slopes generally have inclinations of well over $30^{\circ}$, but slopes too steep to hold soil and vegetation are rather rare except in certain localities, as near the mouth of Loon Creek, on the east side of the Middle Fork near the northern boundary, and in the southeastern part of the quadrangle. The average slope of the ground in the quadrangle as a whole is a little less than $20^{\circ}{ }^{4}$ The only approximately level tracts that exceed 100 acres in extent are the flats at the head of Yankee Fork, in the southeast corner of the quadrangle, of which the largest covers little more than a quarter of a square mile. There are terrace flats at intervals along the Middle Fork and its larger tributaries. These are all individually small, although by combining several of them it has been possible in a few places, such as the Boyle ranch and Meyers Cove, to develop several hundred acres of arable land. Many of the larger streams have rock-cut basins at their heads,

1 U.S. Geog. Board Fifth Rept., p. 293, 1921.

${ }^{2}$ U.S. Geog. Board Decisions, April 1, 1931, p. 4.

3 U.S. Geog. Board Decisions, Dec. 3, 1930, and Jan. 7, 1931, p. 5 .

4 Determined by measurement on the topographic map in 10-minute units by Rich's method. (Rich, J. L., A graphical method of determining the average inclination of a land surface from a contour map: Illinois Acad. Sci. Trans., vol. 9, pp. 195-199, 1917.) 
but these are irregular in detail. There are certain long, narrow ridges which, although not flat, have relief strikingly more moderate than the country in general. These are flanked on both sides by steep slopes that contrast strongly with the gentle contours of the ridge tops. The ridge followed by the "high trail" from Warm Spring Creek toward Sleeping Deer Mountain is an example. There are similar ridges near Norton Lake, south of the Cougar Creek ranger station, and elsewhere in the quadrangle.

The higher peaks in the quadrangle range in altitude from 9,100 to 10,043 feet above sea level; the highest is just north of the flats at the head of Yankee Fork. Twin Peaks, altitude 10,328 feet, is nearly $21 / 2$ miles farther northeast, just outside the quadrangle. It is probably the highest peak in the Salmon River Mountains and one of the highest in Idaho. The lowest point in the Casto quadrangle is at the place where the Middle Fork of the Salmon River crosses the northern boundary. It has an altitude of less than 3,500 feet.

\section{DRAINAGE}

The Middle Fork of the Salmon River swings diagonally across the northwestern part of the Casto quadrangle. Almost the entire quadrangle is drained by this stream and its tributaries. The only exception is an area of about 15 square miles in the extreme southeast corner, which is drained by the Yankee Fork of the Salmon. Besides these two forks, Loon Creek, which flows northward through the middle of the quadrangle, and Camas Creek, which drains its northeastern part, are the principal streams in the quadrangle. Estimates by the water-resources branch of the United States Geological Survey indicate that the Middle Fork above the mouth of Camas Creek has a drainage area of 1,910 square miles and a mean annual flow of $1,360,000$ acre-feet; Camas Creek has a drainage area of 390 square miles and a mean annual flow of 230,000 acre-feet; and Loon Creek has a drainage area of 350 square miles and a mean annual flow of 214,000 acre-feet.

The valley of the Middle Fork is one of the most striking topographic features of the region. It is a tortuous, V-shaped canyon, with an average depth of about 4,000 feet. At intervals for more than 500 feet above stream level there are well-defined, generally gravelcapped terraces, some of the lowest of which are being cultivated. The river flows northeast and then north and joins the canyon of the Salmon River about 25 miles north of the quadrangle. The Middle Fork is a vigorous stream a few hundred feet wide and several feet deep, with numerous small rapids but no falls. The current is swift and the bottom is generally boulder-strewn, so that the stream can be safely crossed on horseback only at certain rather widely separated fords. 
The other streams of the quadrangle are similar to the Middle Fork except that they have even steeper grades and in their upper reaches show the effects of ancient glaciation. (See pp. 88-90.). Most of the tributary streams are noticeably constricted at their mouths and have so piled up alluvium there that they do not enter the main streams quite at grade. There are terraces along these streams similar to those of the Middle Fork but in most places not so well developed.

The minor streams tributary to the Middle Fork enter it approximately at right angles, and some of those feeding the larger tributaries show similar relations to them. A considerable number of the moderate-sized streams flow about N. $40^{\circ} \mathrm{E}$. and S. $40^{\circ} \mathrm{W}$. There are about 60 streams in the quadrangle which for considerable portions of their courses maintain trends within $10^{\circ}$ of these directions. Most of the longer, well-defined ridge crests have similar trends. This northeasterly trend stands out conspicuously in an otherwise heterogeneous topography. As will be explained below, this trend is a reflection of the most prominent fault system in the underlying rocks.

About 65 small lakes are shown on plate 1, and there are numerous others too small to be mapped. Nearly all are in the upper reaches of the streams. Most of them are at altitudes of 8,500 feet or more, and with one exception none are much below 8,000 feet. The exception is Blue Lake, at less than 6,800 feet, which is the result of damming by a landslide; the others are of glacial origin.

\section{NOMENCLATURE OF STREAMS}

Nearly all the streams of any size in the quadrangle have been named by the Forest Service, the nomenclature being based on established usage so far as possible. There is much duplication in stream names, but none within the limits of a single national forest; this is said to avoid all confusion in connection with the Forest Service work. A dozen names are used twice, and a few even more frequently. Seven creeks are distinguished from others nearby only by prefixing the word "Little" to the name. The numerous tributaries distinguished merely as forks of named streams add to the confusion. In the present report where it is necessary to use a stream name that occurs more than once on plate 1 it is generally coupled with the name of a nearby stream not so duplicated. Where Warm Spring Creek is referred to without further designation the large tributary of Loon Creek so named is meant.

\section{CLIMATE}

The Casto quadrangle has long, rather severe winters and short, pleasant summers. There is marked local variation in precipitation, depending on the altitude and on the amount of protection from moisture-laden winds from the west and southwest. Existing Weather 
Bureau records indicate an annual precipitation of 15 to 20 inches in the valley of Loon Creek and similar streams. In the deep canyon of the Middle Fork the precipitation is probably well under 15 inches, perhaps under 10 inches. On the peaks it probably exceeds 25 inches by a considerable amount, perhaps as much as 10 inches. It is thought from personal experience and observation and from the run-off of the streams that the average annual precipitation over the quadrangle is of the order of 25 inches. August is generally the driest month, and the first 6 months are usually the wettest. From late June to late August or early September much of the precipitation falls in brief heavy showers. During this period storms of several days' duration are rare, and it is unusual to have enough rain to hamper travel or outdoor work seriously. During much of the rest of the year the reverse is more nearly true. At the higher altitudes snow may fall at any time of the year, and from September to May, inclusive, much of the precipitation is in that form.

The temperature is generally moderate. Frost may occur at any time but, especially in sheltered valleys, is rare in June, July, and August. In December, January, February, and much of November and March the average temperature rarely exceeds $20^{\circ} \mathrm{F}$., and at times it drops as low as $40^{\circ}$ below zero. One of the striking features of the climate is the marked diurnal range in temperature. Both in winter and in summer shifts of $40^{\circ}$ in a single day are common. In the hottest parts of the summer blankets are required at night.

\section{POPULATION}

The Casto quadrangle is so inaccessible and so mountainous that it is very sparsely inhabited. Within its limits are the almost deserted towns of Casto, Ivers, and Yellowjacket, 4 small ranches along Loon Creek, 1 on Warm Spring Creek, 1 on Marble Creek, and 8 along the Middle Fork. With the exception of three of those along the Middle Fork, the one at the mouth of Loon Creek, and the one on Warm Spring Creek, these ranches are generally inhabited by one or more people throughout the year. Only one ranger station, that on Loon Creek, is ever kept open all the year, and frequently this is closed in the winter.

In the summer more people live at the ranches, and there is an influx of forest rangers, fire guards, mining men, stockmen, and campers. The fire guards are generally on duty from about the beginning of July to the first of September. The summer population, exclusive of people who come in for a week or two for pleasure or for mine assessment work, probably averages about 60 , but it is rare for as many as 20 people, including children, to stay through the winter. This is an average of about one person to every 14 square miles of country in the short summer and one to every 45 square miles in the long winter. 


\section{INDUSTRIES}

The scantiness of the population reflects the lack of industrial opportunities at the present time. Nearly one fourth of the summer inhabitants are employees of the United States Forest Service, a slightly larger number are engaged in mining, and the remainder are stockmen and ranchers and their families.

\section{RANCHING}

The local ranchers raise some cattle and horses and cultivate forage crops for the food of such of these animals as remain during the winter, also small truck gardens and orchards for their own use. Potatoes, rhubarb, and onions are among the more commonly raised vegetables. The fact that it is possible to raise only a small quantity of forage on these ranches limits the number of cattle and horses that can be wintered locally.

Several years ago an attempt was made to winter large herds of sheep along the Middle Fork. Many of the animals died early in the spring, and the project was abandoned. Although a little winter grazing along the Middle Fork is practicable, this range is probably giving its best use as a winter deer range. For this reason it has been made a game reserve.

Cattle and horses from Meyers Cove and other nearby ranches and sheep from ranches along Morgan Creek and the Salmon River and even from more distant localities are driven into the quadrangle to graze in summer. The great distance to localities where large amounts of winter forage can be raised and the shortness of the grazing season introduce difficulties in the successful use of the area for summer grazing. It is generally impossible to trail sheep here before the first of July, and they must leave early in September.

The business of equipping, guiding, or caring for persons from a distance who wish to enter the mountains for sport or recreation is growing in importance in this region. An increasing number of the local people are coming to depend, in part or wholly, on this occupation for their livelihood. The Boyle ranch, in the southern part of the quadrangle, and Meyers Cove and nearby ranches just outside its eastern border are the principal local centers for this activity. Some of the ranchers on lower Loon Creek and on the Middle Fork do more or less of this work. Expeditions are also organized from such nearby towns as Challis and Stanley.

The Casto quadrangle and the great region surrounding it constitute one of the largest stretches of comparatively untouched wilderness remaining in the United States. The scenery is magnificent; the climate in summer is agreeable and healthful; and fish and game exist in abundance and variety scarcely surpassed elsewhere in the United States. These facts make it peculiarly adaptable to development such as is indicated above. 
Mineral deposits were first discovered in the quadrangle in the late sixties, but the principal period of activity was in the final years of the last century and the beginning of the present century, mainly at the Yellowjacket and Lost Packer mines. These and others are described in the last section of this report. Data on production are incomplete, but it is probable that the total production from all lode-mining properties in the quadrangle does not greatly exceed $\$ 1,000,000$. The production from placers is not known, but the total is probably about as large as that from lode mines. Most of it comes from Loon Creek near the old town of Casto.

In recent years little beyond the necessary annual assessment work has been done at any of the mining properties within the quadrangle except the Lost Packer and the Monte Cristo. Even at these two only a small amount of development work has been done during the summer. For more than 10 years no ore has been shipped from the quadrangle except a few sample lots and the product of a little pocket mining in the Parker Mountain district. A little placer mining has been done recently on the Middle Fork and elsewhere, but the total amount of bullion produced is small.

\section{FAUNA AND FLORA}

The Casto quadrangle has rather diversified animal and vegetable life. Plants, especially, show marked differences within short distances, as a result of the sharp variations in conditions caused by the rugged topography and great differences in altitude. There is a decided contrast between the growth on the north and that on the south slopes of the same mountain, and between the vegetation at low altitudes near the Middle Fork and that on the peaks above. To some extent the same is true of the animal life, but the mobility of the animals makes the contrast much less striking.

The more common plants, animals, birds, and fishes are listed below, and some descriptive data are given. Most of this information was supplied for use in this report by A. E. Renner, supervisor of the Challis National Forest, to whom hearty thanks are due for this and many other courtesies. The list of birds was compiled by Donald M. Davidson from observations made in the summer of 1927 . A few supplementary data have been added from observations by the writer.

\section{MAMMALS}

The mammals of the region include mule deer, probably a few elk, mountain sheep and goats, black and brown bears, mountain lions, several varieties of wild cats and foxes, coyotes, gray wolves, marten, mink, otter, beaver, ermine, porcupine, various kinds of ground and tree squirrels, snowshoe rabbits, badgers, and several species of rats and mice. The mule deer are the principal attraction for hunters. 
Elk are occasionally reported in the Casto quadrangle, but if any remain they are so rare that the chance of a hunter's finding one is remote.

Comparatively few mountain goats remain in the quadrangle. They are reported to be most abundant around the head of Brush Creek and are also found near the heads of Shell and Yellowjacket Creeks, on Loon Creek above Trail Creek, and in a few other places.

Mountain sheep are somewhat more abundant. They range in bands of 3 to 20 head or more in rougher country than the deer but not as high up as the goats. The cliffs on the left side of the Middle Fork between White and Brush Creeks are favorite haunts of these animals. Like the deer they generally scatter over the high range in summer and congregate in larger bands, largely along the Middle Fork, in winter. In the latter locality they suffer severely from attacks by wildcats and mountain lions. The lambs are born on the low range, usually in May. Many of them are killed by predatory animals before they are large enough to protect themselves in any way. In addition to such losses, the sheep in this region have suffered severely from scab and other diseases. Nevertheless, the protection afforded by the game laws has enabled them to increase a little in the last 10 years.

The various members of the cat family are rarely seen in summer, but their tracks in winter show that they are by no means rare.

Moderate to small sized black and brown bears are fairly common. They were especially abundant in the summer of 1927 , when a total of about two dozen were seen by the different members of the party in the course of the geologic work. As no attempt was made to seek them, this suggests that bear hunters should have little difficulty in finding as many as they want.

Fur-bearing animals are present in considerable variety and fair abundance but have been little sought. Marten are among the most abundant, but there are numerous others such as mink, otter, ermine, and weasels. A few of the valuable silver foxes range on the high ridges between Loon Creek and Duffield Creek. A few gray wolves have been noted on Mahoney and Lightning Point Creeks. Beaver dams are present on Mayfield, Duck, Camas, Castle Fork of Little Loon, and numerous other creeks, and many of them evidently still contain active beaver colonies, but these animals are now protected by law.

The porcupine is common at all times of the year, especially in the meadows and creek bottoms. There are several kinds of gray and red tree squirrels, and the Columbian ground squirrels, commonly called "picket pin" and "creson", and golden-mantled chipmunks are also abundant. There are various rats and mice, of which the most commonly seen are the wood rats, which infest abandoned cabins. 


\section{BIRDS}

The list of 77 birds, given below, compiled by D. M. Davidson, includes only those seen during about 3 months in the summer of 1927 and hence is probably far from complete. The common names are given at the left and the scientific names at the right.

\section{Treganza heron}

Mallard

American merganser

Turkey vulture

Sharp-shinned hawk

Cooper hawk

Western red-tailed hawk

Golden eagle

Bald eagle

Sparrow hawk

Dusky grouse

Gray ruffed grouse -

Sage hen

California quail

Sora rail

Spotted sandpiper.

Killdeer

Western mourning dove

MacFarlane screech owl

Montana horned owl.

Pacific nighthawk

Black-chinned humming bird (?)

Western belted kingfisher.

Red-shafted flicker

Western pileated woodpecker

Lewis woodpecker.

Red-naped sapsucker

Rocky Mountain hairy woodpecker

Kingbird

Hammond flycatcher

Violet-green swallow.

Tree swallow

Barn swallow

Cliff swallow

Purple martin

Rocky Mountain jay

Black-headed jay

American magpie

American raven

Western crow

Clarke nutcracker

Mountain chickadee

Rocky Mountain nuthatch

Red-breasted nuthatch

Black-eared nuthatch.

Rocky Mountain creeper

Water ouzel

Western house wren

50576-34-2

\section{Ardea herodias treganzai.}

Anas platyrhynchos.

Mergus merganser americanus.

Cathartes aura septentrionalis.

Accipiter velox.

Accipiter cooperi.

Buteo borealis calurus.

Aquila chrysaetos canadensis.

Haliaeetus leucocephalus.

Falco sparverius.

Dendragapus obscurus.

Bonasa umbellus umbelloides.

Centrocereus urophasianus.

Lophortyx californica.

Porzana carolina.

Actitis macularia.

Oxyechus vociferus.

Zenaidura macroura marginella.

Otus asio macfarlanei.

Bubo virginianus occidentalis.

Chordeiles minor hesperis.

Archilochus alexandri.

Megaceryle alcyon caurina.

Colaptes eafer collaris.

Ceophloeus pileatus picinus.

Asyndesmus lewis.

Sphyrapicus varius nuchalis.

Dryobates villosus monticola.

Tyrannus tyrannus.

Empidonax hammondi.

Tachycineta thalassina lepida.

Iridoprocne bicolor.

Hirundo erythrogaster.

Petrochelidon albifrons.

Progne subis.

Perisoreus canadensis capitalis.

Cyanocitta stelleri annectens.

Pica pica hudsonica.

Corvus corax sinuatus.

Corvus brachyrhynchos hesperis.

Nucifraga columbiana.

Penthestes gambeli.

Sitta carolinensis nelsoni.

Sitta canadensis.

Sitta pygmaea melanotis.

Certhia familiaris montana.

Cinclus mexicanus unicolor.

Troglodytes aedon parkmani. 
Canon wren

Rock wren

Catbird

Western robin

Audubon hermit thrush

Willow thrush

Western bluebird

Mountain bluebird

Ruby-crowned knight

Cedar waxwing.

Yellow warbler.

Audubon warbler

Western meadow lark

Yellow-headed blackbird.

Nevada (?) red-wing

Bullock oriole

Brewer blackbird

Nevada cowbird

Western tanager

Lazuli bunting

California purple finch

Rocky Mountain pine grosbeak

Pale goldfinch

Spurred towhee.

Slate-colored junco

Pink-sided junco.

Western tree sparrow (?)

Western chipping sparrow

Song sparrow
Catherpes mexicanus conspersus.

Salpinetes obsoletus.

Dumetella carolinensis.

Turdus migratorius propinquus.

Hylocichla guttata auduboni.

Hylocichla fuscescens salicicola.

Sialia mexicana occidentalis.

Sialia currucoides.

Corthylio calendula.

Bombycilla cedrorum.

Dendroica aestiva.

Dendroica auduboni.

Sturnella neglecta.

Xanthocephalus xanthocephalus.

Agelaius phoeniceus nevadensis.

Icterus bullocki.

Euphagus cyanocephalus.

Molothrus ater artemisiae.

Piranga ludoviciana.

Passerina amoena.

Carpodacus purpureus californicus.

Pinicola enucleator montana.

Astragalinus tristis pallidus.

Pipilo maculatus montanus.

Junco hyemalis.

Junco mearnsi.

Spizella arborea ochracea.

Spizella passerina arizonae.

Melospiza melodia.

\section{FISH}

There are several varieties of game fish in the streams of the quadrangle. Among them are the steel-head trout (Salmo gairdnerii), cutthroat trout (S. clarkii), Dolly Varden trout (S. bairdii), chinook salmon (Oncorhynchus tschawytscha), Rocky Mountain white fish (Coregonus williamsoni), and squaw fish, suckers, and others of little importance to anglers.

\section{FLORA}

Much the greater part of the quadrangle is covered with woodland. Only the inner canyons of the Middle Fork, Camas Creek below Dry Gulch, and the West Fork of Camas Creek, the higher summits, and a few other small areas are comparatively free of trees. Most of the trees are rather small, and, except in groves of saplings, the growth is not dense. There is little merchantable timber, and what there is cannot be economically marketed under present conditions. The unforested areas below about 6,000 feet are generally covered with sagebrush and bunch grasses. Timber line proper is at an altitude of about 9,000 feet, but there are many rocky, windswept ridges well below this that are almost free from trees. Almost every 
part of the quadrangle has at one time or another been swept by forest fires, but there have been few very destructive fires in recent years.

The following lists, compiled by A. E. Renner, show the plants that are most abundant and of most economic importance in this region.

TREES

White fir

Abies eoncolor.

Alpine fir

Abies lasiocarpa.

Engelmann spruce

Picea engelmannii.

White-bark pine.

Pinus albicaulis.

Lodgepole pine

Pinus contorta.

Limber pine

Pinus flexilis.

Western yellow pine

Pinus ponderosa.

Aspen

Populus aurea.

Cottonwood

Populus occidentalis.

Douglas fir.

Pseudotsuga taxifolia.

\section{SHRUBS AND SMALL TREES}

Mountain maple

Acer glabrum.

Alder

Alnus tenuifolia.

Serviceberry

Amelanchier alnifolia.

Bearberry

Arctostaphylos uva-ursi.

Aromatic sage

Artemisia aromatica.

Sagebrush

Artemisia tridentata.

Birch

Betula fontinalis.

Snowbrush

Ceanothus velutinus.

Gooseberry

Grossularia setosa.

Dwarf juniper

Juniperus communis.

Labrador tea

Ledum glandulosum.

Russet buffaloberry

Lepargyrea canadensis.

Ninebark

Opulaster malvaceus.

Chokeberry

Prunus melanocarpa.

Wild currant

Ribes inebrians.

Wild rose.

Rosa nutkana.

Wild raspberry

Rubus strigosus.

Willow (several species)

Salix.

Snowberry -

Symphoricarpos rotundifolius.

Huckleberry

Vaccinium membranaceum.

Small huckleberry

Vaccinium scoparium.

Bitterbrush

Kunzia.

\section{BROAD-LEAVED HERBS}

Arnica

Aster (several species)

Loco (several species)

Balsamroot

Indian paintbrush

Fireweed

Drymocallis.

Daisy (several species)

Ladies' tobacco (several species)
Arnica cordifolia.

Aster.

Astragalus.

Balsamorrhiza sagittata.

Castilleja miniata.

Chamaenirion angustifolium.

Drymocallis glandulosa.

Erigeron.

Eriogonum. 
Wild geranium

Wild iris

Dandelion

Lupine (several species)

Bluebell.

Pentstemon or beardtongue (several species) -

Serrate senecio

Triangular-leaved senecio

Valerian.
Geranium richardsonii.

Iris missouriensis.

Leontodon taraxacum.

Lupinus.

Mertensia ciliata.

Pentstemon.

Senecio serra.

Senecio triangularis.

Valeriana occidentalis.

GRASSES AND GRASSLIKE PLANTS

Western wheatgrass

Slender wheatgrass

Tall mountain bromegrass

Idaho fescue.

Mountain June grass

Dwarf dropseed

Native bluegrass

Squirreltail

Porcupine grass

Elk sedge.
Agropyron spicatum.

Agropyron tenerum.

Bromus marginatus.

Festuca idahoensis.

Koeleria cristata.

Muhlenbergia squarrosa.

Poa confusa.

Sitanion hystrix.

Stipa columbiana.

Carex geyeri.

\section{STRATIGRAPHY}

\section{MAJOR FEATURES}

The Casto quadrangle is a region of igneous rocks with comparatively minor amounts of metamorphosed sedimentary strata. There are no definite means within the quadrangle of determining the age of either igneous or sedimentary rocks, and the tentative ages suggested here are based on more or less satisfactory correlation with formations beyond the limits of the quadrangle.

The largest masses of sedimentary rock are the quartzitic strata in the northeast corner of the quadrangle, here divided into two formations and considered to belong to the Belt series. There are numerous scattered exposures of ancient sedimentary rocks elsewhere in the quadrangle, especially in the vicinity of Ivers and the Boyle ranch. Some of these are of Paleozoic age.

There are two great groups of effusive rocks which originally extended over the whole quadrangle. One of these, the Casto volcanics, of Permian (?) age, consists of lava and pyroclastic rocks of intermediate composition with minor amounts of sedimentary material. The largest mass of such rock extends in an irregular band diagonally northeastward across the middle of the quadrangle, with other masses on each side, especially in the northwestern part of the quadrangle. Volcanic rocks as old as this have not heretofore been recognized in this part of Idaho. The other group, of Oligocene (?) age, has been named the "Challis volcanics", and a part of it, the Yankee Fork rhyolite member, is mapped separately. This group comprises lava, tuff, and breccia of andesitic to rhyolitic composition. The largest 
exposures are in the northwestern and southeastern parts of the quadrangle. Large masses of granodiorite and kindred rocks related to the Idaho batholith, of Mesozoic age, are exposed in the southwestern part of the quadrangle, and smaller masses occur elsewhere. A body of granite, of Miocene age, extends along the valley of the Middle Fork, and kindred masses are exposed in some other places. Granitic rock as young as this has not heretofore been mapped in Idaho. Numerous dikes, mostly of silicic composition, are associated with the Miocene granite.

Three kinds of surficial deposits are mapped. These are glacial deposits, alluvium, and landslide debris. They are described in the section on geomorphology.

\section{ANCIENT SEDIMENTARY AND IGNEOUS ROCKS}

Nearly all the sedimentary rocks are highly metamorphosed and are clearly much older than the Casto volcanics. They are so scattered among the igneous rocks that precise correlation between the different areas cannot be made, especially as fossils appear to be entirely wanting. For purposes of description they are therefore grouped under geographic headings. Another group of rocks consisting largely of sedimentary material is described under the general heading "Injection gneiss."

\section{BELT SERIES (ALGONKIAN) NEAR YELLOWJACKET}

\section{GENERAL FEATURES}

About 18 square miles in the northeast corner of the quadrangle is underlain by quartzitic strata. This small area is the southwestern extension of the great mass of similar rock which, as Umpleby ${ }^{5}$ has shown, underlies much of Lemhi County. He assigned these rocks to the Algonkian system but did not subdivide them into formations. There is little if any doubt that these rocks belong to the Belt series, which covers large areas in Montana and northern Idaho. They cannot at present be correlated with known formations in that series, however, and for convenience of description local designations have been given to the two subdivisions mapped in the Casto quadrangleYellowjacket formation and Hoodoo quartzite. If these rocks are eventually correlated with established formations elsewhere, the nomenclature may have to be revised.

As the ancient sedimentary rocks within the quadrangle are much disturbed and exposures are unsatisfactory, a plane-table traverse was made for about $4 \frac{1 \%}{2}$ miles along the road up Yellowjacket Creek from the Yellowjacket mill, in order to get some conception of the lithology and stratigraphic relations of the strata. Observations were confined

\footnotetext{
$\$$ Umpleby, J. B., Geology and ore deposits of Lemhi County, Idaho: U.S. Geol. Survey Bull. 528, pl. 1, pp. $30-32,1913$.
} 
to a narrow strip of country on each side of the line of traverse, where rock is exposed at short intervals. The slopes on both sides are forestcovered, and in general exposures on them are poor. Under thesecircumstances it is obvious that unrecognized faults may exist. Such faults, if present, would introduce errors into the estimates of thickness of the units but would probably not seriously affect the general. interpretation of stratigraphic relations. It is clear, from ripple marks, cross-bedding, and other indications, that the strata are successively younger to the northeast. In the first $1 \frac{11}{4}$ miles of the traverse the sedimentary rocks are much disturbed and cut by numerous dikes. The strata here are locally overturned and dip steeply southwest. Farther east there is less disturbance, and the beds have an average strike of about N. $20^{\circ} \mathrm{W}$. and a dip that decreases from nearly vertical to about $35^{\circ} \mathrm{NE}$. near the end of the traverse. The succession, starting near the Yellowjacket mill, is as follows:

\begin{tabular}{|c|c|c|}
\hline Formation name & Character & $\begin{array}{c}\text { Thickness } \\
\text { (feet) }\end{array}$ \\
\hline $\begin{array}{l}\text { Not exposed within the quadrangle. } \\
\text { Hoodoo quartzite... }\end{array}$ &  & $\begin{array}{l}\text { a } 865+ \\
3,560 \\
4,300 \\
1,030 \\
100 \\
1,650 \\
1,700 \pm\end{array}$ \\
\hline
\end{tabular}

a Top not reached.

\section{YELIOWJACKET FORMATION}

The Yellowjacket formation is named for the town and mining district of Yellowjacket. It includes the dark-gray, more or less argillaceous quartzite so prominent in this district and the lenses of metamorphosed calcareous material exposed near the Yellowjacket. mill and elsewhere. These lenses of calcareous material evidently are stratigraphically in the lower part of the formation as here exposed. The actual base of the formation does not appear in this vicinity. To judge by the measured section above described and by the exposures as mapped the thickness of the Yellowjacket formation is somewhat less than 9,000 feet, of which from a few hundred to more than 1,500 feet consists of calcareous beds. The formation covers more than half of the area of sedimentary rocks in this part of the quadrangle and is widely exposed near Yellowjacket, east of Hoodoo Creek, and on Lake Creek.

Nearly all the mines and prospects in the Yellowjacket mining district are in this formation. The Yellowjacket mine and some of the others contain representatives of the calcareous beds, but the largest exposures of such rock do not appear to contain economically valuable minerals. 
Quartzitic beds.-The quartzite of the Yellowjacket formation is sufficiently argillaceous to weather readily. Natural exposures, except in freshly cut stream banks and cliffs, are crumbled and more or less bleached.

On fresh fractures the color is various shades of gray. The commonest colors approximate Ridgway's deep gull-gray and puritan gray. ${ }^{6}$ Weathered surfaces are much darker. There is considerable jointing and in many localities rather pronounced cleavage, generally parallel to the bedding, which in places, especially in the more argillaceous varieties, has gone far enough to give the rock a slaty character. Ripple marks are not uncommon. In most exposures the attitude of the bedding must be inferred from these marks and the cleavage parallel to them, but in some of the lighter-colored, more quartzitic varieties bedding can be clearly discerned on cross fractures. The latter rocks are made up of small cross-bedded lenses, rarely more than a fraction of an inch thick.

The rock is composed mainly of quartz with subordinate amounts of plagioclase, biotite, chlorite, sericite, and iron oxide and scattered grains of epidote and zircon. Probably the average rock contains fully 70 percent of quartz. Biotite, or chlorite formed from biotite, makes up more than half of the remainder. The micaceous minerals are in matted aggregates, with only rough parallelism. The quartz is recrystallized in interlocking grains, with little suggestion of the original sedimentary texture, and the average diameter of the grains. is little more than 0.1 millimeter.

Calcareous beds.-The best exposures of the calcareous beds of the Yellowjacket formation are on the main road near the Yellowjacket mill. The beds interfinger with the dominant quartzitic beds and die out within short distances in both directions along their strike. This interfingering is on a smaller scale than can be represented on plate 1 , and the boundaries there shown are of necessity somewhat diagrammatic and generalized. Similar rock is poorly exposed on the east side of Hoodoo Creek. As judged by chips in the soil the distribution of the calcareous beds is essentially as shown on plate 1 . Some of the beds included in the quartzitic Yellowjacket on the map, because they resemble it in general lithologic character, contain calcareous silicates and might more properly be called calcareous beds. Among these may be mentioned scapolite-bearing beds on the south side of Yellowjacket Creek, in line with the main body of the calcareous beds as mapped, and some of the beds which contain calcite and scapolite southeast of the Columbia mine.

The calcareous rocks vary markedly in appearance. Some of them resemble the banded hornfels of the southern part of the quadrangle, with its closely spaced, somewhat irregular dark-green, black, and

6 Ridgway, Robert, Color standards and nomenclature, pls. 53, 47, 1912. 
gray beds. Others are nearly white rocks closely mottled with dark clusters of metamorphic minerals. Still others resemble the dark impure quartzite composing the major part of the Yellowjacket formation but contain varying amounts of carbonates and lime silicates.

The calcareous rocks are coarser-grained than the other Belt rocks in this vicinity. Their principal component is quartz in somewhat irregular grains 0.03 to over 0.10 millimeter in maximum dimension. Other minerals present include calcite, scapolite, biotite, epidote, chlorite, amphibole, which is in part actinolite, plagioclase, and apatite.

\section{HOODOO QUARTZITE}

The Hoodoo quartzite is named from Hoodoo Creek, in the northeast corner of the quadrangle. Only about 6.5 square miles is occupied by this formation within the quadrangle, but its outcrops can be seen for many miles to the north. It crops out on the west slope of the valley of Hoodoo Creek and is well exposed around its head north of the quadrangle boundary. It extends westward around the head of Lake Creek, and scattered masses of it crop out on both sides of Camp Creek. East of Hoodoo Creek it swings around so that two blocks of it project into the northeast corner of the quadrangle. The eastern block reaches the level of Yellowjacket Creek about half a mile beyond the eastern boundary. This mass was measured in the traverse described above and has a thickness of 3,560 feet. The wide exposure between Hoodoo and Lake Creeks suggests that the thickness there may be as much as 1,000 feet greater, but as this mass is overthrust on the Yellowjacket formation below, there is so much structural disturbance within it as to cast doubt on estimates of thickness.

Typical specimens of Hoodoo quartzite are, on freshly fractured surfaces, nearly white with a tinge of pale vinaceous gray, but joint surfaces tend to be light brownish because of thin films of limonite. The rock, originally massive, has been intricately jointed, and in some places, especially the ridge between Hoodoo and Lake Creeks, jointing is so extremely developed that the rock appears shattered. Although the rock is generally very hard and resistant to weathering, outcrops of bedrock at many places on this ridge are small, and the ground in their vicinity is littered with angular fragments of the quartzite. The bedding is not distinct, but on close examination faint closely spaced and somewhat irregular bands that evidently correspond to the original bedding can generally be seen. In much of the rock it is possible to discern small-scale cross-bedding. Near both the top and the bottom of the formation the banding becomes more distinct. Near the bottom in the northeast corner of the quadrangle there appears to be a gradation into the Yellowjacket formation, in contrast to the fault contacts farther west. Rock 
resembling the Yellowjacket formation is interbedded with the nearly white quartzite in beds from a fraction of an inch to several feet thick.

The top of the Hoodoo quartzite does not appear to be exposed within the Casto quadrangle. On Yellowjacket Creek to the east, however, the Hoodoo quartzite is overlain by a banded, somewhat calcareous quartzite. The contact here also appears to be gradational.

Rock representative of the Hoodoo quartzite is composed of quartz, feldspar, sericite, and chlorite. Probably most of it contains 70 to 80 percent of quartz. Most of this is in interlocking grains about 0.2 millimeter in average diameter, but large grains, perhaps the remains of original clastic fragments, are fairly common. These larger grains average somewhat over 0.75 millimeter in length and 0.25 millimeter in width. Feldspar in clear, unaltered grains nearly 0.5 millimeter long makes up as much as 10 percent of the rock. Much of this is microcline, but there is also considerable albite plagioclase. The remainder of the rock is composed of white mica and chlorite, mostly in tiny matted flakes.

\section{AGE OF THE SEDIMENTARY ROCKS NEAR YELLOWJACKET}

The Yellowjacket and Hoodoo formations and the similar strata. overlying them to the northeast form part of the mass of Algonkian sedimentary rocks mapped by Umpleby $^{7}$ as underlying much of Lemhi County. Observations in the Casto quadrangle and neighboring regions show conclusively that they are older than Ordovician and accord with his conclusion that they are Algonkian and hence belong to the Belt series.

The nearest area in which Belt strata have been studied in detail is the Philipsburg quadrangle, ${ }^{8}$ Montana, 120 miles in an air line northeast of Yellowjacket. About half of this distance has been covered by Umpleby's reconnaissance referred to above, and Calkins' work has proved that Belt rocks extend more than 25 miles southwest of Philipsburg, but the intervening unmapped area is largely underlain by granitic rocks, making direct correlation between the two areas of Belt rocks difficult.

Umpleby ${ }^{9}$ suggested that the beds in the southern part of the Yellowjacket district-that is, the Yellowjacket formation of the present report-might correspond to the Wallace formation of the Coeur d'Alene district, because of their broad petrographic similarity. He. also suggested that the quartzite near the Black Eagle mine, which belongs to the Hoodoo quartzite of the present report,

7 Umpleby, J. B., Geology and ore deposits of Lemhi County, Idaho: U.S. Geol. Survey Bull. 528, pp. 30-32, pl. 1, 1913.

${ }^{8}$ Calkins, F. C., and Emmons, W. H., U.S. Geol. Survey Geol. Atlas, Philipsburg folio (no. 196), 1915.

Umpleby, J. B., op. cit., p. 32. 
may correspond to the Revett quartzite of the Coeur d'Alene district, but the Hoodoo quartzite appears to overlie the Yellowjacket formation, whereas the Revett is considerably below the Wallace in the Coeur d'Alene district. It is clear, therefore, that lithology alone, the only available basis for comparison, is insufficient to establish correlations between the Belt formations near Yellowjacket and those elsewhere.

\section{ALGONKIAN DIABASE}

Distribution.-At several places in the northeast corner of the quadrangle the Belt strata are cut by small, generally irregular dikes of a basic igneous rock which, on weathered surfaces, resembles diabase. Such rock is present on dumps of the Yellowjacket and Black Eagle mines, but the only outcrop large enough to be shown on plate 1 is on the old road a short distance below the road to the Columbia mine. Other exposures appear near the head of Lake Creek, on the road to the Black Eagle mine just north of the quadrangle, and elsewhere.

Character.-The diabase is a dark-greenish rock so altered that few minerals other than chlorite can be distinguished with the unaided eye. Under the microscope it consists largely of labradorite, uralitic hornblende, and biotite, with more or less chlorite, epidote, apatite, secondary quartz, iron oxide, sericite, and locally carbonate. Most specimens appear to consist more than half of ferromagnesian material, all of which has been recrystallized and altered. Pyroxene, doubtless originally abundant, has been completely uralitized. Biotite, a deeply pleochroic brown variety, appears to have crystallized later than most of the other minerals. It may have formed during a comparatively recent stage in the complicated history of the rock. The feldspar generally shows crystal form, and the prisms average over a millimeter in length. The texture, where unaltered, is ophitic. This and the composition indicate that the rock is uralitic diabase.

These dikes cut both of the Belt formations, but no such metamorphosed rocks are known in any of the younger formations. A similar diabasic rock was noted in a complex of injection gneiss and quartz diorite on Camas Creek below the mouth of Soda Creek, but it is much more altered than the other igneous rocks here and in all probability was present in the old sedimentary rocks prior to the intrusion of the quartz diorite.

Part of the metamorphism of the diabase, at least of that at and near the Black Eagle mine, is to be attributed to the effeet of mineralization supposed to have taken place in Mesozoic time, but the uralitization probably occurred much earlier. It appears that the degree of metamorphism of the diabase in the northeastern part of the quadrangle even exceeds that of the diabase, similarly associated 
with Belt strata, which Umpleby and Jones ${ }^{10}$ consider the oldest igneous rock in Shoshone County.

Age.- It is believed that the diabase of the Casto quadrangle, like the Belt strata it intrudes, is of Algonkian age, although the possibility that it is younger cannot be excluded.

ALGONKLAN AND PALEOZOIC SEDIMENTARY ROCKS NEAR BOYLE RANCH GENERAL FEATURES

The ancient sedimentary rocks in the vicinity of the Boyle ranch are in two groups. One crops out over about 4 square miles extending from the north side of Canyon Creek near Ivers southward to the Boyle ranch, mainly in one irregular mass with several small outliers nearby. The other group is exposed over about $13 / 4$ square miles on the east side of Loon Creek and north side of Mayfield Creek east of the Boyle ranch. Except where unconformably overlain by Challis volcanies north of Ivers and by Casto volcanies on the ridge east of the Boyle ranch, the strata are completely surrounded and intruded by igneous rocks of several kinds and are in part covered by glacial and other detritus, the larger and thicker masses of which are shown on plate 1. The area of schist north of Ivers contains innumerable dikes, data on which are given in the description of the Lost Packer mine. The mapped boundaries of the schist east and west of this mine are of necessity arbitrary. Glacial deposits, tạlus, and vegetation effectively conceal the details, but it is certain that the intricacies are greater than could be adequately represented on a map several times the scale of plate 1 . The area of about a third of a square mile west of the mine mapped as mainly underlain by Tertiary dike rocks contains also numerous fragments of schist, and some schist is included in the dike rocks east of the mine. The metamorphic effects of such intrusions as these on the sedimentary rocks here and elsewhere in the quadrangle are discussed by W. H. Newhouse on pages $68-72$.

The numerous intrusions with their accompanying metamorphism, coupled with previous dynamic metamorphism, and the extensive concealment of the bedrock by detritus and vegetation make it difficult to ascertain the structure and stratigraphic succession of the sedimentary rocks here. Several small faults are known, and others doubtless exist, adding to the uncertainties.

In many exposures the bedding cannot be discerned, and where visible its attitude has been more or less influenced by local, surficial movements. The relations and thickness of the different units, therefore, can only be inferred from the irregular boundaries as plotted on the topographic map and from determinations of strike and dip. In the area between Ivers and the Boyle ranch the strata evidently form a syncline in which the oldest rock is schist of unknown thickness.

10 Umpleby, J. B., and Jones, E. L., Geology and ore deposits of Shoshone County, Idaho: U.S. Geol. Survey Bull. 732, p. 9, 1923. 
This is overlain successively by impure dolomitic limestone which may have a thickness of roughly 1,800 feet, about 600 feet of quartzite, and about 200 feet of impure dolomitic limestone above the quartzite. There are also masses of coarsely crystalline limestone and banded hornfels which probably belong to the lower limestone member. East of the Boyle ranch the succession is somewhat different: the lowest member is schist, overlain by a lenticular body of quartzite with a maximum thickness of roughly 300 feet, and this in turn is covered by impure dolomitic limestone with a maximum thickness of nearly 600 feet. In both localities the schist appears to lie unconformably under the limestone and quartzite, and in the area east of the Boyle ranch there is a marked unconformity between the limestone and the overlying Casto volcanics, the basal beds of which contain pebbles of the limestone.

The schist contains the Lost Packer and Monte Cristo mines. This and the other sedimentary rocks in the vicinity of the Boyle ranch also contain a number of other prospects, on most of which annual assessment work is kept up. The flux used in the smelter at Ivers when it was in operation was obtained from quarries in the limestone a few miles to the south.

\section{SCHIST}

For purposes of description the schist may be divided into the mass around the Lost Packer mine, that south of Ivers, that on the west side of Loon Creek near Casto, and that east of the Boyle ranch, near the Monte Cristo mine. The schist in each of these localities is so highly foliated and contorted as a result of dynamie metamorphism as to render it impossible to identify the original bedding positively, although banding that may have resulted from bedding is visible in some of the more massive rocks. In a very general way the schistosity near the Lost Packer and that south of Ivers strike northwest and dip in both directions. The schist near Casto is so poorly exposed and so contorted where it is visible as to preclude an estimate of its average attitude. That near the Monte Cristo strikes in general nearly east and dips north. In addition to the intense regional metamorphism which these rocks have undergone they have also been subjected to marked metamorphism related to the igneous intrusions which cut them. In some specimens the foliation planes are liberally sprinkled with knots of minerals mainly of contactmetamorphic origin.

The color of cross fractures of the schist near the Lost Packer mine is dull greenish black. On cleavage surfaces the rock is much lighter colored and more silvery. This rock is intricately foliated but fairly hard. Tunnels driven in it need little timber except where the rock has been weakened by the crushing and hydrothermal alteration connected with the ore deposition. In such places the rock is soft 
and slippery, and openings in it are difficult to maintain. When blasted it yields in blocks along shear planes, resulting in irregularshaped mine workings. Much of the schist in the other localities is softer than that at the Lost Packer mine and breaks more readily along the foliation planes, forming comparatively thin, more or less irregular plates and slivers.

The rock in the Monte Cristo workings resembles that at the Lost Packer, but much of it is coarser and less greenish and has a deeppurplish cast.

The schist is composed largely of quartz and biotite with some muscovite, chlorite, rutile, and in places other minerals, such as andalusite and amphibole. Except for a faint banding visible in some places no suggestion of the original sedimentary texture remains. The quartz grains range from a few hundredths of a millimeter up to about 0.2 millimeter in maximum dimension. The average size is about 0.1 millimeter.

The unconformity at the top of the schist is best shown east of the Boyle ranch by the irregular upper surface of the schist, the fact that the quartzite and limestone are in overlapping relation, and the greater regional metamorphism in the schist. Also, the schistosity close to the contact does not accord with any structure in the overlying quartzite and limestone, and banding in the schist supposed to correspond to bedding is generally very steep, whereas the dip of the overlying strata rarely exceeds $25^{\circ}$. The evidence elsewhere is less complete but similar.

\section{DOLOMITIC LIMESTONES}

The dolomitic limestones in both areas near the Boyle ranch are essentially similar, and one description suffices for them. They consist mainly of dark-blue to nearly black fine to medium grained beds with some red and gray bands and a few beds of dark-gray argillite. Bedding is distinct only where limestone and argillite alternate, but original laminae, especially in the more argillaceous beds, can be seen on close inspection.

The dolomite, like other sedimentary rocks of the quadrangle, has been recrystallized. It is mostly thick-bedded or massive, and its original texture is reflected only in rather poorly defined banding due to differences in size of grain and to laminae of impurities. Where not appreciably affected by contact metamorphism, it consists of dolomite and calcite, with considerable quartz and variable minor amounts of graphitic carbon, muscovite, and biotite. The dolomite and calcite grains have maximum diameters of 0.3 millimeter. Quartz grains are mostly minute but in some relatively coarse grained layers attain diameters of 0.15 millimeter. Although they are doubtless of detrital origin, the evidence has been obseured by their recrystallization from rounded into irregular shapes. 
Contact-metamorphic silicates are locally present throughout the. areas, and where abundant the appearance of the rock is profoundly changed, as shown in detail on pages 68-72. The argillite beds have. been rendered somewhat schistose by regional metamorphism, some of them sufficiently to resemble the underlying schist; but on the whole they have not undergone nearly so much metamorphism as. the schist.

\section{MARBLE}

At several places south of Ivers marble occurs in sufficiently large masses to be mapped. These masses, as shown on plate 1, are so. nearly isolated from the other sedimentary rocks by igneous intrusions. and small faults that their stratigraphic relations cannot be positively determined. Their general relations strongly suggest that the marblebelongs with the lower limestone member, but rock sufficiently calcareous to have been quarried for smelter flux is present in the strata belonging to the upper member on Deer Creek.

The marble is a moderately coarse-grained crystalline rock and, where pure, shows no bedding. In many exposures, however, there are lenses of silicate material doubtless corresponding to originally less calcareous beds in the limestone. The pure marble is nearly white where fresh and clean and is composed mainly of dolomite in grains averaging 0.5 millimeter or more in diameter; but nearly all of it is more or less stained with limonite, which tends to be concentrated along thin bands. These bands probably mark the original bedding. In most exposures the marble also contains irregular bands, roughly parallel to the limonitic bands, which are dark gray to nearly black on fresh fractures and consist mainly of calcite with small amounts of contact-metamorphic silicates. These bands, although coarser-textured, resemble and grade into the dark dense bands of the banded hornfels described below.

\section{BANDED HORNFELS}

One of the most striking members of the sedimentary series is the banded hornfels. Rock of this type is closely associated with and grades into the marble in the flux quarries south of Ivers and is grouped. with that rock on plate 1 . Similar rock also exists in the small block of limestone mapped in generalized fashion on the west side of Loon Creek north of Casto.

The banded hornfels is composed of alternate bands of limestone and dense argillaceous material from a quarter of an inch to an inch. or more in thickness. The limestone bands are rusty and, though originally fairly pure carbonate, now consist largely of metamorphicminerals. The argillaceous bands are hard, are green or dark blue, 
and also contain abundant metamorphic minerals. Similar banded hornfels occurs in the Wood River and Yellow Pine districts. ${ }^{11}$

\section{QUARTZITE}

The quartzitic member of this sedimentary series is well exposed on the north side of Mayfield Creek. It is also abundant south of Ivers, but the exposures there are rather poor. The unstained quartzite is white and light gray, but most of it is stained various shades of red, brown, and yellow by iron oxides. A little of the quartzite south of Ivers is pale pinkish buff to gray, distinctly micaceous, and somewhat schistose. Some of the quartzite north of Mayfield Creek is brecciated. In most exposures it is a massive rock with little suggestion of bedding, although here and there banding that probably corresponds to bedding can be discerned in it. Nearly all the quartzite is composed essentially of quartz in interlocking grains 0.5 to 3 millimeters in maximum diameter, with very subordinate amounts of muscovite and insignificant quantities of other minerals.

\section{$A G B$}

There are no data that permit close determination of the age of these rocks. The pronounced angular unconformity at the top of the schist suggests that it is Algonkian, as unconformities between lower Paleozoic formations in Idaho and adjacent States show little or no angular discordance. There is no close resemblance, however, between this thoroughly metamorphosed rock and the Belt rocks near Yellowjacket.

The rocks above the schist, in spite of the absence of the lower limestone east of the Boyle ranch, may be regarded as of approximately one age. The fact that they were subjected to considerable dynamic metamorphism before pebbles derived from them were incorporated in the basal beds of the Casto volcanics, of Permian (?) age (p. 31), assigns them to a distinctly earlier period.

Umpleby ${ }^{12}$ suggested that the quartzite south of Ivers resembles beds at Gilmore, Lemhi County, which he originally assigned tentatively to the Cambrian and later believed to be of Ordovician age. He also suggested ${ }^{13}$ that the massive blue dolomitic limestone resembles Ordovician strata at the same locality. Both the quartzite and the limestone near Gilmore, however, are, according to his description, less metamorphosed than the strata near the Boyle ranch.

11 Umpleby, J. B., Westgate, L. G., and Ross, C. P., Geology and ore deposits of the Wood River district, Idaho: U.S. Geol. Survey Bull. 814, pp. 12-13, 1930. Schrader, F. C., and Ross, C. P., Antimony and quicksilver deposits in the Yellow Pine district, Idaho: U.S. Geol. Survey Bull. 780, p. 142, 1926.

12 Umpleby, J. B., Some ore deposits in northwestern Custer County, Idaho: U.S. Geol. Survey Bull. 539, p. 92, 1913; Geology and ore deposits of the Mackay region, Idaho: U.S. Geol. Survey Prof. Paper 97, p. $25,1917$.

${ }^{13}$ Umpleby, J. B., Geology and ore deposits of Lemhi County, Idaho: U.S. Geol. Survey Bull. 528, pp. 32, 33, 1913. 
Of the rocks familiar to the present writer, the assemblage in the vicinity of the Boyle ranch most nearly resemble equally metamorphosed strata of Ordovician age in the Bayhorse district, Custer County, ${ }^{14}$ and strata of unknown but presumably Paleozoic age in the Yellow Pine district, Valley County. ${ }^{15}$ Because of these resemblances the limestone, quartzite, and shale near the Boyle ranch may be tentatively regarded as mainly Ordovician.

\section{DOLOMITE MARBLE NEAR SHOR'T CREEK}

Along the Middle Fork of the Salmon River near the mouths of Short, Aparejo, and Little Aparejo Creeks, south of the Jones ranch, there are several inclusions of marble and related rock in the pink granite. The five inclusions large enough to be mapped in somewhat generalized fashion on plate 1 are mainly coarsely crystalline marble. Almost all the material in the irregular lenses mapped is pure-white, thoroughly recrystallized dolomite without admixture of other minerals. Some of the grains exceed 3 millimeters in diameter, and the average is probably about 2 millimeters. Close to the trail on both sides of Little Aparejo Creek there are smaller masses of more impure metamorphic rock, not shown on the map. These in part border the dolomite marble and in part are detached from it. They are finegrained and nearly black, for the most part, and many are rather indefinitely and irregularly banded. Most of them do not now contain carbonate. Some are greenish or contain green streaks of serpentine. The black rock contains interlocking grains of quartz, scapolite, biotite, muscovite, chlorite, rutite, apatite, a little plagioclase, and some mineral which is now completely sericitized.

Some of the granite near these inclusions is sheared and colored greenish by the development of chlorite and other silicate minerals, which indicate that material from the inclusions has been absorbed in the granite.

In their present state these inclusions are so different from any of the other sedimentary rocks of the quadrangle that no correlation of them can be offered. The limestone in the Casto voleanies north of Cache Creek is the nearest carbonate rock, and this is not dolomitic and has a different texture. The schist near the head of Woodtick Creek contains some carbonate, but not in masses of comparable size. The dolomitic marble near the Boyle ranch, although 18 miles away in a straight line, resembles the inclusions lithologically more closely than any other in the quadrangle but is finer-grained and more impure.

\footnotetext{
if Ross, C. P., Geology and ore deposits of the Bayhorse quadrangle, Idaho: U.S. Geol. Survey Bull. (in preparation).

is Schrader, F. C., and Ross, C. P., Antimony an'd quicksilver deposits in the Yellow Pine district, Idaho: U. S. Geol. Survey Bull. 780, pp. 140-142, 1926.
} 
BLACK SCHIST NEAR WOODTICK CREEK

Two irregular bodies of nearly black schist near the head of Woodtick Creek occupy a total area of a little over 2 square miles. The schist fragments near Cabin Creek, described elsewhere in this report, are lithologically similar to this schist and probably are essentially equivalent to it stratigraphically.

Most of the rock is black and moderately fine grained, in part massive as a result of baking by the nearby granitic mass, in part schistose. Some of the schist has bedding lamination approximately parallel to the schistosity, and in this variety, near the head of the most northerly branch of Grouse Creek, light-gray limestone is interbedded.

The black more or less schistose rocks, whether laminated or not, consist mainly of quartz, biotite, chlorite, and epidote with a little iron oxide and apatite and varying amounts of plagioclase, mostly oligoclase-andesine. The chlorite is in part an alteration product of the biotite. Parallel arrangement of the micaceous shreds and quartz grains is strikingly developed, even in rock that appears massive in the hand specimen. Most of the plagioclase is in roughly rectangular grains some of which are as much as 0.5 millimeter in maximum dimension, rarely longer, but the diameter of the grains in the main mass of the rocks rarely exceeds 0.05 millimeter. There are a few large calcite grains, which may have been introduced through meteoric circulation from the nearby limestone.

Some of the rocks have an igneous appearance, resulting mainly from the phenocrystlike large plagioclase grains, but these were clearly formed during the complete recrystallization of the rock in the process of metamorphism. Much of the rock contains a higher proportion of plagioclase and ferromagnesian minerals than is to be expected in an ordinary metamorphosed sedimentary rock. Its composition appears due in part to recrystallization of a feldspathic sandstone, graywacke, or tuffaceous rock and in part to additions of igneous material from the local quartz monzonite. The texture of some of the coarser-grained, less schistose rocks close to the northern border of the schist mass suggests the latter possibility. This rock consists largely of irregular interlocking grains of quartz with maximum diameters as large as 0.4 millimeter, surrounded by finer-grained quartz, which appears to have been formed by crushing of the larger grains. In addition there are aggregates of tiny, clean-cut flakes of fresh biotite and grains of fresh plagioclase, both of which have maximum dimensions of a few hundredths of a millimeter. The aggregates show no effect of the crushing to which the quartz has been subjected. They were formed comprotict
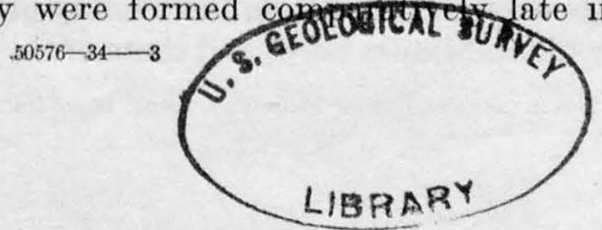
possibly as a result of introduction of material from the nearby Miocene quartz monzonite.

The limestone is interbedded with the upper part of the black and thin-banded schist on the ridge west of Woodtick Creek. Some of the schist contains small irregular lenses of coarse calcite, but most of the limestone is fine-grained to dense and rather evenly banded, with about 15 bands to the inch. It is composed mainly of calcite but contains some quartz. The individual masses are only a few feet thick. Such rock was noted only in one locality. The black schist containing the calcite lenses also contains small quartz stringers, some of which are copper-stained. A little prospecting has been done on these stringers.

\section{SCATYERED EXPOSURES}

About 20 other small exposures of sedimentary rock scattered throughout the quadrangle are shown in plate 1, and there are many others too small to be shown. Most of them are enclosed in granitic rocks of the Idaho batholith, and a few are enclosed in Miocene dikes. They are correlated on lithologic evidence with one or another of the formations already described and need no detailed description. The most conspicuous are in the southwestern part of the quadrangle, and most of them are confidently correlated with the Paleozoic rocks near the Boyle ranch. Those below Casto near Tincup Creek are closely associated with the Casto volcanics but are believed to mark irregularities of the floor beneath. Quartzite inclusions near Two Point Peak, in the northwestern part of the quadrangle, and near Duck Creek, north of Meyers Cove, are also thought to be Paleozoic. Darkgray quartzite above the injection gneiss between Camas and Grouse Creeks is correlated with the Hoodoo quartzite of the Belt series. The quartzite at the mouth of Little Loon Creek, tentatively correlated as Paleozoic, may also be of Hoodoo age. Inclusions of gray-green schist in dikes are found near Sheldon Peak, and inclusions of black schist and limestone occur near the head of Cabin Creek, near the center of the quadrangle.

\section{CASTO VOLCANICS (PERMIAN P)}

\section{DISTRIBUTION}

The volcanic strata older than Oligocene (?) in and near the Casto quadrangle have been named the "Casto volcanics." ${ }_{16}$ The rocks of this formation crop out over about 231 square miles in the Casto quadrangle. The largest mass stretches diagonally northeastward across the middle of the quadrangle from the vicinity of Casto past Meyers Cove. There is another in the vicinity of Warm Springs ranger station. Another extends southward from the vicinity of Two Point Peak, on the west side of the Middle Fork, and there are several

\footnotetext{
${ }_{16}$ Ross, C. P., Ore deposits in Tertiary lava in the Salmon River Mountains, Idaho: Idaho Bur. Mines and Geology Pamphlet 25, p. 7, 1927.
} 
smaller bodies elsewhere. The formation is known to extend north and east beyond the limits of the quadrangle but has not been traced far beyond its southern and western boundaries.

\section{TOPOGRAPHIC EXPRESSION}

In many places, especially in the southern part of the quadrangle, the andesitic beds that predominate in the Casto volcanics have abundant rough outcrops, which from a distance generally have a dull mottled-green appearance. Cliffs are rare, although they occur near the mouth of Lightning Point Creek and elsewhere. The talus is generally in angular blocks of considerable size. Characteristically it is not slabby, but some of the lighter-colored rocks of the formation, especially near Sleeping Deer Mountain, weather in distinctly thin slabs.

\section{GENERAL CHARACTER}

Nearly all the strata belonging to the Casto volcanics are of eruptive origin, and both flows and tuff are represented. The tuffs are largely water-laid but contain very little material not obviously of igneous origin. Coarse conglomerate, which contains metamorphosed sedimentary rocks with a tuffaceous matrix, is present in a few places. One bed of limestone was noted. The volcanic rocks are all distinctly altered, in contrast to the comparatively fresh Tertiary rocks in this part of Idaho. The obscurity of the bedding, which has resulted from the development of new minerals during metamorphism, makes it difficult to determine the details of structure and stratigraphy. In some places flow banding in the lava and stratification in the tuff indicate the attitude of the strata, but over considerable areas the outcrops give little indication of this attitude. However, partings, which are best discerned at a distance, approximately parallel the bedding where visible and indicate the general attitude where other evidence is lacking.

\section{LAVA AND TUFF}

The effusive rocks that make up by far the greater part of the Casto volcanics may be divided for purposes of description into andesitic rocks and rhyolitic rocks. The two varieties are so intimately interbedded with each other that they have not been separated on the map, but there are marked petrographic differences between them. The andesitic, generally dark-colored rocks, are much the more abundant. In many localities only this type is present. The light-colored rhyolitic rocks are in the upper part of the formation,

\section{ANDESITIC ROCKS}

The dark-colored beds grouped as andesitic rocks are so mucb altered as to make precise determination difficult. Most of them are lava flows of the approximate composition of sodic andesite and 
dacite, but quartz latite and latite are also represented. Both flow breccias and coarse tuffs are present, and the two are not readily distinguished.

The andesitic rocks are rather massive and, viewed broadly, present a monotonously uniform appearance. They are generally colored in dull purplish and greenish shades, but bluish, reddish, and yellowish rocks are included in places. Many of them originally had a glassy groundmass, now devitrified, but with flow structure still plainly visible under the microscope. This structure, together with the presence of quartz and feldspar phenocrysts that were broken during flowage, gives a clastic appearance to the rock. Inclusions of rock fragments in the glass add to this appearance, and many of these fragmental flows cannot be distinguished from tuff without the aid of the microscope. Some of the dark-colored rocks were originally obsidian with few phenocrysts or included fragments, but these are exceptional. Spherulitic texture, so common in parts of the Challis volcanics, is absent in the andesitic rocks of the Casto voleanics. Flow banding sufficiently marked to be visible to the unaided eye is uncommon in the Casto volcanics but is prominent in several localities near Camas Creek below Meyers Cove and is present along Warm Spring Creek and elsewhere. The andesitic rocks are in general plentifully and uniformly sprinkled with nearly white phenocrysts from less than 0.5 millimeter to 3 millimeters or more in diameter. Some of the rocks contain small rounded areas filled with aggregates of quartz, generally with chlorite and epidote, that are probably amygdules. The more silicic rocks contain small quartz phenocrysts.

The minerals characterizing the rocks are feldspar, quartz (in part secondary), chlorite, biotite, epidote, black iron oxide (in part titaniferous), apatite, and various fine micaceous decomposition products. Most of the feldspar is plagioclase ranging in composition from oligoclase to andesine. Subordinate amounts of orthoclase can be detected in some specimens. The biotite is in all specimens much bleached and chloritized and in many is completely destroyed. Much of the altered biotite contains sagenitic intergrowths of rutile, showing that it was originally titaniferous. The shape of some aggregates of decomposition products suggests that hornblende was formerly present. In places the rocks contain veinlets and irregular masses of red jasper.

\section{RHYOLITIC ROCKS}

The rhyolitic rocks are especially well developed on Sleeping Deer Mountain and on the nearby ridges around the heads of the forks of Liberty Creek and Pole Creek, and somewhat similar rocks are exposed in the valley of Bridge Creek and in less abundance in certain localities in the northeastern part of the quadrangle. 
Near the head of Trail Creek, 3 miles south of Shellrock Peaks, in the northwestern part of the quadrangle, there are beds petrographically indistinguishable from some of the fine-grained light-colored strata near Sleeping Deer Mountain. On the summit of the ridge here and in line of strike with these beds there is an outcrop of darkgreenish lava, typical of much of the Casto volcanics, surrounded by rocks that clearly belong to the Challis volcanics. The dashed-line boundary on plate 1 shows the approximate outlines of the rocks that are correlated petrographically with the Casto volcanics. The relations are evidently due to faulting, which is known to have been prevalent in this locality, although exposures are too obscure to permit the accurate tracing of faults along the boundaries of the Casto volcanics.

The rhyolitic rocks are light colored, and most of them are finegrained, almost chertlike, without visible phenocrysts. Others, especially on and near Sleeping Deer Mountain, are strikingly spherulitic. These have a stony appearance and a pallid drab-gray to somewhat greenish gray color, which serve to distinguish them from the glassy, highly colored spherulitic rocks characteristic of parts of the Challis volcanics. Some of the light-colored rocks near Bridge Creek are pyroclastic, containing fragments of rhyolitic lava an inch in maximum diameter in an originally glassy matrix.

The light-colored rocks consist so largely of devitrified glass that their composition is indeterminate under the microscope. They appear to consist essentially of orthoclase, sodic plagioclase, and quartz with minor amounts of white mica and chlorite. They are thus rhyolitic, but some may contain sufficient plagioclase to be classed as quartz latite.

\section{CONGLOMERATE}

At intervals along the contact of the Casto volcanics with the sedimentary rocks north of Mayfield Creek there is a basal conglomerate of variable thickness, probably nowhere more than a few score feet. This rock consists of subangular to rounded pebbles from 1 to 4 inches in diameter composed of metamorphosed sedimentary rocks, such as immediately underlie the conglomerate, and of volcanic rocks typical of the andesitic facies of the Casto volcanics. The matrix is tuffaceous, and none of the pebbles noted appear to be derived from any formations except those mentioned. Along the high trail from a point near the head of Sheldon Creek westward to the head of the east fork of Rock Creek, in the east-central part of the quadrangle, there are outcrops at intervals of a somewhat similar tuffaceous conglomerate containing poorly rounded or very irregular pebbles and boulders of schist, ranging from a fraction of an inch to several feet in maximum dimension, and less abundant pebbles of white quartzite. The matrix here also is tuffaceous. 
In many places some of the tuff in the Casto volcanics is conglomeratic and contains subangular to rounded pebbles an inch or more in maximum diameter. The pebbles, so far as noted, are all of igneous rock, and nearly all are similar to the neighboring volcanic strata of the same formation. The only exceptions are small beds of tuffaceous conglomerate containing pebbles of an aplitic rock exposed here and there near the head of Liberty Pole Creek and the north side of Cache Creek. The source of these pebbles is not known. The aplitic rock does not correspond to that in dikes known in the quadrangle, although it somewhat resembles some of the dike rocks associated with the Idaho batholith. It consists essentially of quartz, microcline, and oligoclase with a little chloritized biotite. The diameter of the feldspar grains ranges from 0.6 to 1.5 millimeters. The feldspars are somewhat sericitized, and the rock is about as much altered as dikes related to the Idaho batholith, but its texture is more strikingly hypidiomorphic than is characteristic of those dikes.

\section{LIMESTONE}

Near the summit of the 9,512-foot peak north of Cache Creek, near the head of the south fork of Grouse Creek, there is a small body of limestone in the Casto volcanics, the only one known in this formation. The limestone exposure is about 200 feet long in an east-west direction and 20 to 40 feet wide.

This rock is in part white, in part gull-gray. ${ }^{17}$ The gray bands are somewhat siliceous, but the abundant white material is composed essentially of calcite in somewhat elongate rounded grains, whose maximum diameters are between 0.03 and 0.14 millimeter. There is a subordinate amount of white mica in small shreds and a little quartz. The mica and calcite grains have a fairly regular parallel arrangement.

\section{THUCKNESS AND STRATIGRAPHIC RELATIONS}

As is to be expected in such a volcanic formation, there are marked variations in the details of stratigraphy in different localities. Distinctive beds of widespread occurrence that would be useful as horizon markers are lacking. These facts, coupled with the uncertainty as to the attitude of the bedding in many exposures, made it impracticable to measure the thickness of the formation directly or to determine the details of structure or stratigraphy except in certain small areas. The map and structure sections on plate 1 show that fully 5,000 feet of beds belonging to the Casto volcanics must be present along the middle reaches of Loon and Warm Spring Creeks. Section 3 suggests that the thickness in the vicinity of Shell Creek is much greater, but the excess is probably to be explained by the minor

${ }^{17}$ Ridgway, Robert, op. cit., pl. 53. 
faults and folds that are certainly present here. Both north and south of this locality the formation thins rapidly. On the north side of Mayfield Creek, in the southern part of the quadrangle, the total thickness present is only about 4,000 feet, and in the northern part of the Custer quadrangle, which adjoins the Casto quadrangle on the south, the Challis voleanies generally rest directly on the early Paleozoic strata. In the northern part of the Casto quadrangle, north of Camas Creek, only about 2,000 feet of Casto volcanics are exposed between Soda and Aparejo Creeks. Here the volcanics are intruded by and may have been in part displaced by Miocene granite, but their rapid thinning to the east and north cannot thus be explained. Near the head of Cave Creek there is a few hundred feet of Casto volcanics between metamorphosed sedimentary rock below and Challis voleanics above. About $2 \frac{1}{2}$ miles farther north the Challis volcanics lie directly on the eroded surface of Hoodoo quartzite. - In the northwest corner of the quadrangle, however, the Casto volcanics are thicker. The complex faulting in that area has not been worked out in detail, but with due allowance for this it is clear that several thousand feet of this formation is present.

Wherever the Casto voleanics rest on the old sedimentary rocks there is clear evidence of unconformity. The sharp difference in degree and character of metamorphism is in itself sufficient evidence, but in addition angular discordance between the volcanics and the underlying strata is in most places either visible or strongly suggested. North of Mayfield Creek, where the base of the volcanics is best exposed, there is a basal conglomerate in which the pebbles from the underlying schist and quartzite show that those rocks were about as much metamorphosed before deposition of the conglomerate as they are now. The conglomerate near Sheldon Peak, although not at the base of the formation, gives similar evidence of the great time interval between the deposition of the Casto volcanics and that of the strata immediately below them.

Both the character of the conglomerate at the two localities and the shape of the contact as mapped north of Mayfield Creek indicate that the first eruptions of the Casto volcanics issued on a surface of considerable relief. The contact north of Mayfield Creek as shown on plate 1 now has a maximum difference of altitude of about 1,500 feet within less than 2 miles. Parts of this contact, especially in the Loon Creek slope, are very poorly exposed, and some of the irregularities in it may result from events subsequent to deposition, now undecipherable, but the satisfactory exposures on the north side of Mayfield Creek show clearly that the original contact was irregular. In several places in the part of the Loon Creek slope mainly underlain by Casto volcanics, and so mapped on plate 1, there are chips of schist and limestone and scattered blocks of these rocks in the soil. 
Some of the larger blocks may be essentially in place. If the soil could be removed it would probably be found that the chips and blocks. represent projections of the underlying sedimentary rocks surrounded by the later volcanics.

The contact between the Casto volcanics and the overlying Challis strata likewise shows both structural and erosional unconformity. The structural discordance is well shown on the ridges around Cottonwood Creek and its various branches, especially the fork to the south, which heads below the 9,631-foot peak. (See pl. 1.) Here the Casto volcanics near the contact dip $25^{\circ}$ and more to the north, whereas the Challis volcanics dip to the south and east, generally at low angles.

The upper contact of the Casto volcanics north of Mayfield Creek is irregular. The old volcanics crown the ridge at altitudes near 9,000 feet, and the overlying Challis volcanies crop out in a narrow band on the north side of this ridge with their base at an altitude of about 8,000 feet. The Casto volcanics appear in general to dip northward at an average angle of about $20^{\circ}$, and the Challis volcanics in the strip referred to are essentially horizontal. If the present difference of about 1,000 feet in relief results from erosion of the Casto volcanics before the deposition of the Challis beds, it indicates a fairly rugged topography in this locality in pre-Challis time. This may account for the fact that only about 4,000 feet of Casto volcanics appears to be present here.

In the northeast corner of the quadrangle, north of Cave Creek and south of Middle Fork Peak, the Casto volcanics thin notably. The surface of Hoodoo quartzite on which the Challis volcanics lie west of Camp Creek is irregular in detail and is evidently an erosion surface. Thicknesses of several thousand feet of Casto volcanics are exposed on the west side of the Middle Fork only a few miles away, and their comparative scarcity here suggests that in this vicinity also there may have been considerable erosion in the interval between the end of the Casto eruptions and the beginning of those of Challis time.

The relations between contacts and topography shown on plate 1 suggest that with such exceptions as those noted above the contact between these two volcanic formations is fairly smooth; however, it must be emphasized that in most places the actual contact is not clearly exposed, and the exact attitude of the beds on either side of it cannot be determined. Hence generalization is inevitable, and the contacts as sketched are smoother than they are in nature. The existence of such generalization will be evident, for example, if the sketched contacts in the northwestern part of the quadrangle are compared with the attitude of the beds, especially the Challis volcanics, as shown by strike and dip symbols on plate 1. Evidently there are numerous small faults in this area which escaped detection during the mapping. 


\section{AGE AND CORRELATION}

As the Casto volcanies lie unconformably above the old sedimentary rocks and are cut by the Idaho batholith they must be later than early Paleozoic and earlier than upper Mesozoic. More definite assignment eannot be made on the basis of evidence in the Casto quadrangle, but consideration of the geology of neighboring regions leads to the suggestion, as stated elsewhere ${ }^{18}$ that the Casto volcanics may be stratigraphically equivalent to similarly metamorphosed volcanic strata of Permian (Phosphoria) age in western Idaho and eastern Oregon.

\section{ROCKS RELATED TO THE IDAHO BATHOLITH (MESOZOIC)}

The Casto quadrangle differs from most other parts of central Idaho in that most of its granitic rock is of Tertiary instead of Mesozoic age, but the eastern border of the great Idaho batholith (Mesozoic) projects into the quadrangle and is accompanied by several petrographically related rocks which are regarded as marginal and satellitic to it. Although the existence of granitic rocks of these two ages has been definitely established, it is not everywhere possible to correlate individual masses with certainty. The principal rock of the Idaho batholith, here as elsewhere, has the composition of a basic quartz monzonite, with granodioritic facies. It is even-grained, slightly gneissic, and generally somewhat altered and consists mainly of microcline, plagioclase, abundant quartz, biotite, and very subordinate hornblende, with intergrowths of plagioclase and quartz as a characteristic minor feature. In contrast, the principal Tertiary granitic rock is a somewhat basic granite, of comparatively coarse and irregular texture, which, like the older rock, consists mainly of two feldspars, quartz and biotite, but is characterized by abundant perthite and micropegmatite. The respective subsidiary masses, each on the whole less siliceous than the related main mass, are less easy to distinguish from one another, and with the large gaps in the stratigraphic record in this region some uncertainty in correlation is inevitable.

\section{QUARTZ MONZONITE}

Definition and distribution.- The average composition of the portions of the main mass of the Idaho batholith which lie within the quadrangle is approximately that of quartz monzonite. Hence these rocks in general will be so designated, although there is consider-

\footnotetext{
18 Ross, C. P., Ore deposits in Tertiary lava in the Salmon River Mountains, Idaho: Idaho Bur. Mines and Geology Pamphlet 25, p. 7, 1927.
} 
able variation, and in some exposures the rock is not strictly a quartz monzonite. The rock mapped as quartz monzonite is part of a single mass, all of which was intruded at essentially the same time. One finer-grained mass of somewhat later date is exposed on and near Trail Creek and is mapped separately as white quartz monzonite, but with this exception the 62 square miles of granitic rock in the southwestern part of the quadrangle and the $3 \frac{1}{2}$ square miles of similar rock near the middle of the western boundary are included in the quartz monzonite. The fragmentary exposures on Horse and Little Loon Creeks are correlated with the quartz monzonite, because of lithologic similarity.

Character.- The quartz monzonite is a rather light gray, in part greenish, rarely porphyritic, moderately coarse grained rock of normal granitic texture except that there is a suggestion of gneissic structure, more pronounced in some exposures than in others. The gneissic structure appears to have resulted from flowage prior to consolidation of the rock, rather than from subsequent pressure. On Nelson Creek and to some extent elsewhere there are small schlieren, composed mainly of hornblende and biotite.

The rock consists essentially of quartz, potash feldspar, much of which has microcline twinning, oligoclase-andesine, biotite, and locally small amounts of muscovite and hornblende. Hornblende was identified in only 3 of the 31 thin sections examined. Minor amounts of apatite and titanite are generally present, and pyrite and magnetite are visible in some specimens. Varying amounts of alteration products, such as chlorite, sericite, epidote, calcite, and secondary quartz, are present but rarely abundant. Nearly all the biotite shows at least incipient alteration. Myrmekitic intergrowths of plagioclase and quartz are common but not abundant. Micrographic intergrowths of quartz and microcline occur exceptionally. Plagioclase and ferromagnesian minerals especially have a tendency to exhibit euhedral crystal form. The longer diameters of their grains vary in different specimens from somewhat less than 1 millimeter to over 4 millimeters, with the average nearer the lower figure.

The table below gives an analysis of a sample from Mayfield Creek, representative of much of the quartz monzonite, also its calculated norm and position in the quantitative classification, as well as its approximate mineral composition (mode). The biotite appears to be an iron-rich variety and contains some titanium, as indicated by sagenite in some flakes, which accounts for most of the titanium in the analysis. 
Analysis of quartz monzonite from Mayfield Creek, Casto quadrangle

[Analyst, J. G. Fairchild]

\begin{tabular}{|c|c|c|}
\hline Analysis & Norm & Mode \\
\hline $\begin{array}{l}\mathrm{SiO}_{2} \\
\mathrm{Al}_{2} \mathrm{O}_{3} \\
\mathrm{Fe}_{2} \mathrm{O}_{3} \\
\mathrm{FeO}^{2} \\
\mathrm{MgO} \\
\mathrm{MaO}\end{array}$ & 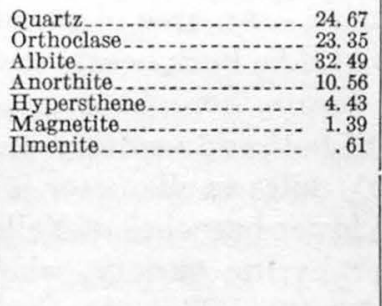 & 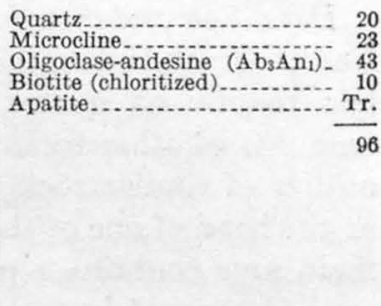 \\
\hline
\end{tabular}

Class $1^{*}$, order 4, rang 2, subrang 3 (4).

WHTTE QUARTZ MONZONITE

Definition and distribution.-The irregular masses of granitic rock older than the Miocene granite near the Middle Fork between Sunflower and Cougar Creeks, in the west-central part of the quadrangle, and the mass that cuts the typical quartz monzonite near Trail Creek, in the southwestern part, are composed of essentially the same kind of rock. It is somewhat finer grained and characteristically more nearly white than the typical quartz monzonite of the Idaho batholith but is only a little more silicic and potassic than that rock. The differences in composition are not sufficient to take it out of the quartz monzonite group, and it is therefore termed white quartz monzonite.

Relation to the Idaho batholith.-The similarity between the white quartz monzonite and that described as typical of the Idaho batholith in this region is so great, both in composition and in degree of alteration, as to suggest a close affinity between them. In some places, particularly on Range Creek and along the Middle Fork above that stream, there are rocks intermediate in appearance between the two, and in places it is difficult to decide with which variety a particular exposure should be classed. Wherever the relations can be observed the pale finer-grained rock cuts the gray coarser rock. Generally the contact is irregular in detail, especially in the southwestern part of the quadrangle. Here the white rock is in part in the form of dikes, some of them only a few feet wide, cutting the coarser-grained quartz monzonite. On the east side of Trail Creek the contact between the two is fairly clean-cut although not everywhere well exposed. On the west side, however, the white rock forms such an irregular network of small dikes that the relations could not be accurately shown even on a map several times the scale of plate 1 . The generalized boundary where this irregularity is particularly striking is represented by a dashed line on plate 1 .

From the data outlined above it is believed that the white quartz monzonite is a somewhat more silicic and potassic differentiate of the 
same magma that formed the main Idaho batholith and consolidated somewhat later than the main mass.

\section{QUARTZ DIORITE}

Definition and distribution.-An area of nearly 9 square miles along Camas Creek and up the Middle Fork nearly to Grouse Creek is underlain mainly by quartz diorite, complexly intermingled with minor amounts of other rocks of both sedimentary and igneous origin. An outlier of similar rock $1 \frac{1}{2}$ miles in diameter is exposed to the north at the head of one of the lower branches of Yellowjacket Creek. The main area contains a porphyritic variety, which is mapped and described separately (pp. 39-40). The quartz diorite is so intimately associated with a local injection complex that no boundary line is drawn between the two on plate 1. In the field, rock that appeared to be dominantly igneous was mapped as quartz diorite, and rock that was dominantly sedimentary was mapped as injection complex. The two merge with each other and are genetically interrelated. Inclusions of extremely altered sedimentary rock in quartz diorite are especially prominent along Camas Creek from its mouth to a point near the mouth of Soda Creek.

The relations of the two formations are further complicated by the presence of small masses of other igneous rocks and by the fact that some of the Miocene granite in the vicinity is modified and resembles the more silicic facies of the quartz diorite. The quartz diorite and the Miocene granite, though fundamentally different, have both incorporated material from the sedimentary rocks here and therefore have certain features in common; furthermore, their contacts with each other are intricately irregular in places. The other igneous rocks here comprise diorite and Miocene dikes. All the larger masses of diorite are mapped separately, but in some places, particularly near the bridge across Camas Creek, small irregular bodies of diorite that cut and in part grade into the quartz diorite are too small and too intimately related to the quartz diorite to be distinguished in mapping. The larger Miocene dikes, mainly pink granophyre, are shown, but fragments in talus indicate that there are in addition numerous little dikes and irregular masses of such rock, which cut the quartz diorite in places.

At intervals along Yellowjacket Creek below the mouth of Buckhorn Creek there are exposures of gray rocks that probably are essentially the same as the quartz diorite. They nowhere extend more than a few feet above stream level, and in this precipitous canyon they are exposed over areas much too small to show on plate 1 .

Character.-As is indicated above, the character of the rock mapped as quartz diorite varies considerably. Most of it is a moderately dark gray medium-grained rock, with gneissic structure only slightly 
developed or entirely absent. Some of it, especially on the Middle Fork slope, contains variable amounts of pinkish-buff feldspar.

The typical quartz diorite consists essentially of plagioclase, biotite, quartz, and hornblende, with a little orthoclase in places, and microscopic apatite and titanite are generally present. The average rock contains 60 to 70 percent of plagioclase, which generally is oligoclase-andesine but in some of the more silicic facies is as sodic as oligoclase. Much of the plagioclase has well-developed zoning. Orthoclase is absent in most of the rock and probably nowhere exceeds a few percent. Ferromagnesian minerals generally make up 20 to 35 percent of the rock. In most of the rock they comprise biotite and somewhat less abundant hornblende, more or less intergrown, with, in places, a little augite as well. In most of the rock there is little more than 5 percent of quartz and in places even less, but in rock of igneous texture and appearance associated with the gneissic rocks near Camas Creek the quantity of quartz present exceeds 60 percent.

The quartz diorite has a somewhat irregular texture. Much of the plagioclase is in prisms with frayed ends, which exceed 1 millimeter in length. The quartz does not have crystal form, but much of it is over 1 millimeter in diameter. Many of the ferromagnesian grains are of comparable size. Nearly half the rock, however, is made up of grains averaging about 0.5 millimeter in diameter. The slightly gneissic texture results in large part from the arrangement of the ferromagnesian minerals in roughly parallel lines. This arrangement was apparently brought about by flowage prior to complete consolidation of the rock. In places, however, the gneissic appearance results from crushing after the rock was nearly or quite consolidated. The rock in these places contains bands of comminuted feldspar and quartz in which the grains show strain and many have maximum dimensions of small fractions of a millimeter, alternating with bands that appear little strained or crushed and have essentially the texture of the average rock.

\section{PORPHYRTTIC QUARTZ DIORITE}

Distribution.-The quartz diorite with large phenocrysts is well exposed at the mouth of Yellowjacket Creek and covers three quarters of a square mile on the ridge between Camas and Grouse Creeks. Some tendency to development of a similar texture was noted in the quartz diorite elsewhere, but these two occurrences are the only ones large enough to be mapped. Exposures in the cirques on the Camas Creek side of the ridge above mentioned show conclusively that there is a gradation between the porphyritic and the normal quartz diorite, and the two are therefore shown on plate 1 without any intervening boundary line. 
Character.-The rock closely resembles the quartz diorite described above except that it contains rectangular phenocrysts of white feldspar, some of which are nearly an inch long, though most are considerably smaller. The specimens examined contain 5 to 15 percent of quartz, 54 to 63 percent of feldspar, and 23 to 41 percent of ferromagnesian minerals, mainly biotite. The feldspar is largely oligoclase-andesine, but the large phenocrysts are distinctly more sodic. A little orthoclase is present in places. Hornblende is everywhere subordinate and is absent from some specimens.

\section{AGE OF THE QUARTZ DIORTTES}

It is clear that the two quartz diorites described above are of essentially the same age. The porphyritic rock is principally the marginal facies, but there is every gradation between the two types, and a certain amount of distinctly porphyritic rock is present well within the main mass of normal quartz diorite.

The relations between these and the other granitic rocks are so complicated and confusing that their relative age has not been established. There is abundant evidence along Camas Creek and the Middle Fork that the Miocene granite cuts the quartz diorite. The quartz diorite is more similar to the quartz monzonite of the Idaho batholith than to typical Miocene granite, although more basic than either. Some of the more basic rock associated with the quartz monzonite along the Middle Fork near Range and Marble Creeks is closely similar to the typical quartz diorite of the area near Camas Creek. On the other hand, there is a resemblance between the gray facies of the Miocene granitic rocks on Little Woodtick Creek and elsewhere and the more silicic facies of the quartz diorite. It is considered most probable that the quartz diorites are related to the Idaho batholith, but the possibility that they are early products of the Miocene intrusive activity has not been definitely disproved.

\section{DIORITE}

Distribution.-Small masses of diorite are mapped near the confluence of Camas and Woodtick Creeks and along Loon Creek near Horse Creek. An outcrop of similar rock projects through the Miocene granite on the north side of Aparejo Point. As already noted, a little of the rock mapped as quartz diorite is poor enough in quartz to be called diorite. This is similar to the diorite in the masses here described. The total area of exposures of such rock in the quadrangle is somewhat more than a square mile.

Character.-The diorite has a moderately fine grained appearance, and as the black minerals make up 35 percent or more of the rock it is as a whole dark gray or almost black. It is composed essentially of andesine, biotite, and hornblende, with some augite in places and generally a little apatite. 
Age.-The diorite is clearly older than the Miocene granite and is intimately associated with the quartz diorite. The two dioritic rocks appear to grade into each other near the mouth of Woodtick Creek. Hence the diorite, like the quartz diorite, is believed to be related to the Idaho batholith and of essentially the same age.

\section{DIKES RELATED TO THE IDAHO BATHOLTTH}

PYROXENITE

In and near a prospect near the head of Deer Creek, northwest of the Boyle ranch, the quartz monzonite is cut by several small dikes of a nearly black pyroxenite containing more than 90 percent of augite, which forms rounded grains a few tenths of a millimeter in diameter. It contains a little untwinned feldspar, which is unevenly distributed, and it is impregnated with irregular aggregates of pyrrhotite grains, some of which are enclosed in quartz. The pyrrhotite and quartz were clearly formed later than the augite, and probably after the consolidation of the rock.

\section{KERSANTITE}

Dikes of fine-grained, nearly black lamprophyre, mainly kersantite, a few inches to a few feet in width, cut the quartz monzonite in several places. They are particularly abundant and well exposed in the cirques at the head of Nelson Creek, a tributary of Mayfield Creek. They are so intimately associated with the quartz monzonite that there seems little doubt that they are genetically related to that intrusion.

The dikes on Nelson Creek are composed of a fine-grained intergrowth of labradorite laths and biotite flakes with a little interstitial quartz. The feldspars reach 1 millimeter in maximum length. Dikes cutting the quartz monzonite near the mouth of Duffield Creek and the white quartz monzonite on the ridge east of Bernard Creek, in the southwest corner of the quadrangle, are similar except that the biotite is bleached and chloritized.

\section{APLITE}

Small aplitic dikes related to the Idaho batholith occur in only a few places in the quadrangle. They are abundant near the head of Nelson Creek and are present in noteworthy amount on Bernard Creek and on the ridge north of the main fork of Mayfield Creek. The rock is fine-grained and consists essentially of alkali feldspar and quartz, with little or no mica. Somewhat similar aplitic dikes are abundant in the schist at the Lost Packer mine and are discussed in the description of that mine.

Here and there the quartz monzonite contains small, irregular masses and stringers of coarse-grained or pegmatitic rock, with a composition resembling that of the aplite, which tend to merge into 
the surrounding quartz monzonite. Well-developed pegmatite dikes: are absent, and even these stringers are nowhere abundant within the quadrangle. Some of the best examples are on the west side of Bernard Creek near the southwest corner of the quadrangle. Here the feldspar in the pegmatitic rock attains lengths of nearly an inch.

\section{INJECTION GNEISS}

Definition and distribution.-The term "injection gneiss" is here used to designate rocks whose appearance and structural relations: show that they are of sedimentary origin but have been greatly modified by both the Mesozoic and the Miocene granitic intrusions. The gneiss ranges from obviously sedimentary rock with minor amounts of igneous material to rock of granitic appearance. Similar material is extensively exposed elsewhere in central Idaho, along the borders of the Idaho batholith.

Almost all the injection gneiss in the Casto quadrangle retains. recognizable sedimentary characteristics. The exceptions are intrusive bodies of true granitic rock which range from a fraction of an inch to scores of feet in thickness but are so intermingled with and in part gradational into the gneiss that they have not been separately mapped. The principal mass of injection gneiss covers about 4 square miles on the east side of the Middle Fork near and north of Grouse Creek. Small masses of similar rock not separately mapped are included in the quartz diorite to the north and east, especially along the trail on the north side of Camas Creek between its mouth and Soda Creek. Similar rock is exposed on a spur above the head of Cave Creek and around the head of an unnamed tributary of Yellowjacket Creek somewhat farther northwest. The largest of these are mapped, but there are a number of much smaller bodies not shown. Farther up the Middle Fork, between the mouths of Little Loon and Marble Creeks, there are minor amounts of similar gneiss, not separately mapped, in the two varieties of quartz monzonite there exposed. Close to the river on both sides inclusions of gneiss from a few inches to a few feet in dimensions are sporadically exposed. There are also a few small bodies of injection gneiss in both the pinkish granite and its hornblendic relative on and near Yellowjacket Creek, especially close to stream level on Yellowjacket Creek.

Character.-The most abundant variety is well represented in the main mass near Grouse Creek and in the isolated masses above Little. Loon Creek. It is a dark-gray, nearly black medium to fine grained rock, more or less distinctly banded, and ranges from bedded rock with local limestone beds and with little superficial evidenee of injection through typical injection gneiss with lit-par-lit banding to rock of dominantly igneous texture. (See pl. 2, A.) The more irregular bands of igneous material in the injection gneiss grade into dikes. that cut the rock without relation to original bedding or schistosity. 


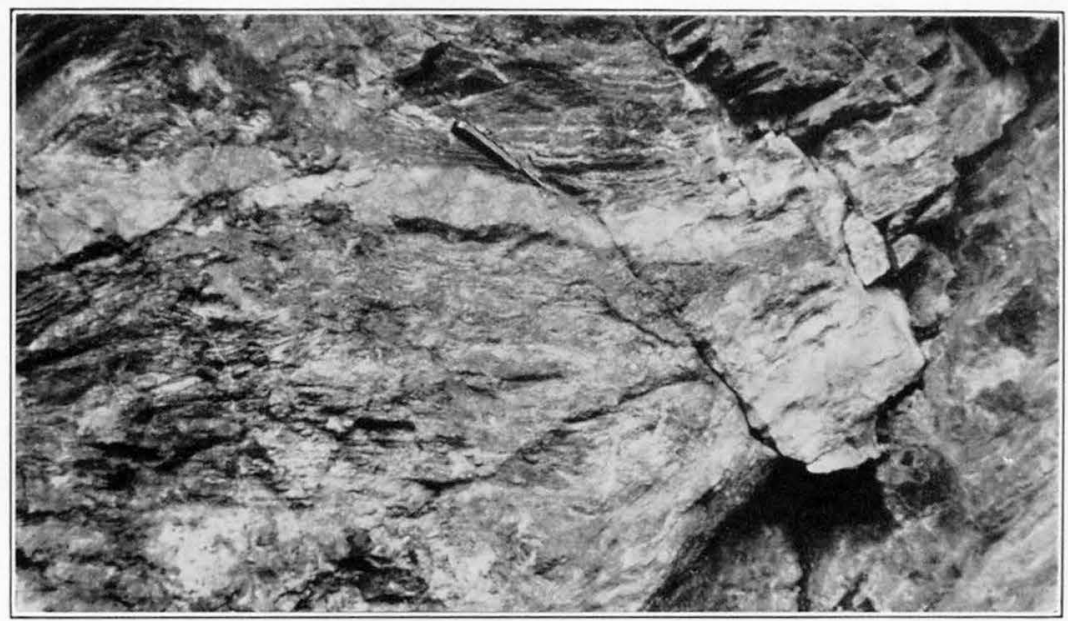

A. IIT-PAR-LIT STRUCTURE IN GNEISS.

On the Middle Fork near Jones ranch.

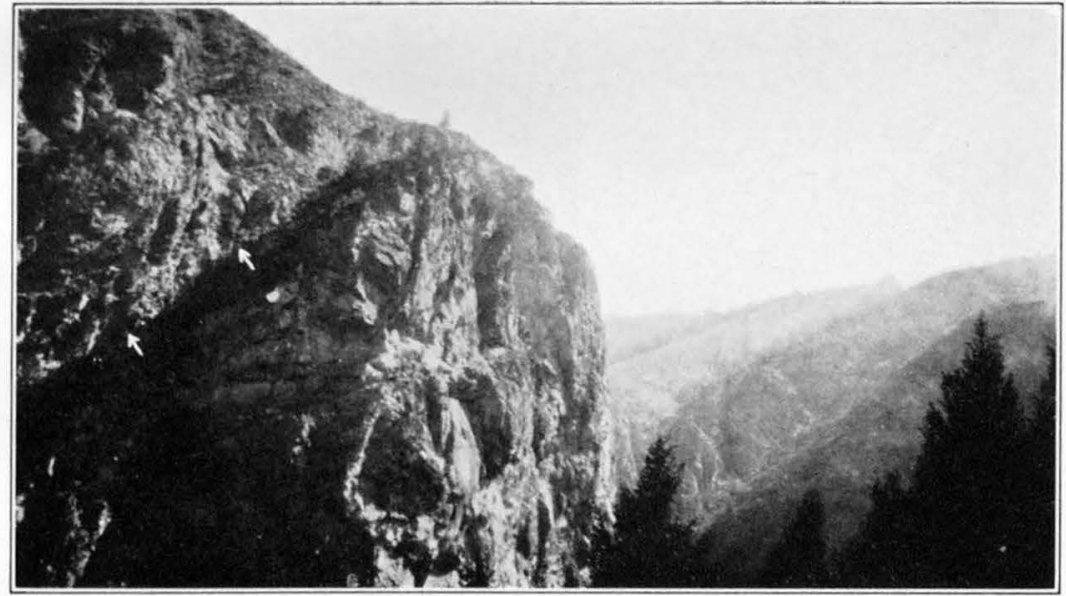

B. CONTACT BETWEEN PINK GRANITE AND INJECTION GNEISS On the Middle Fork above Camas Creek. 


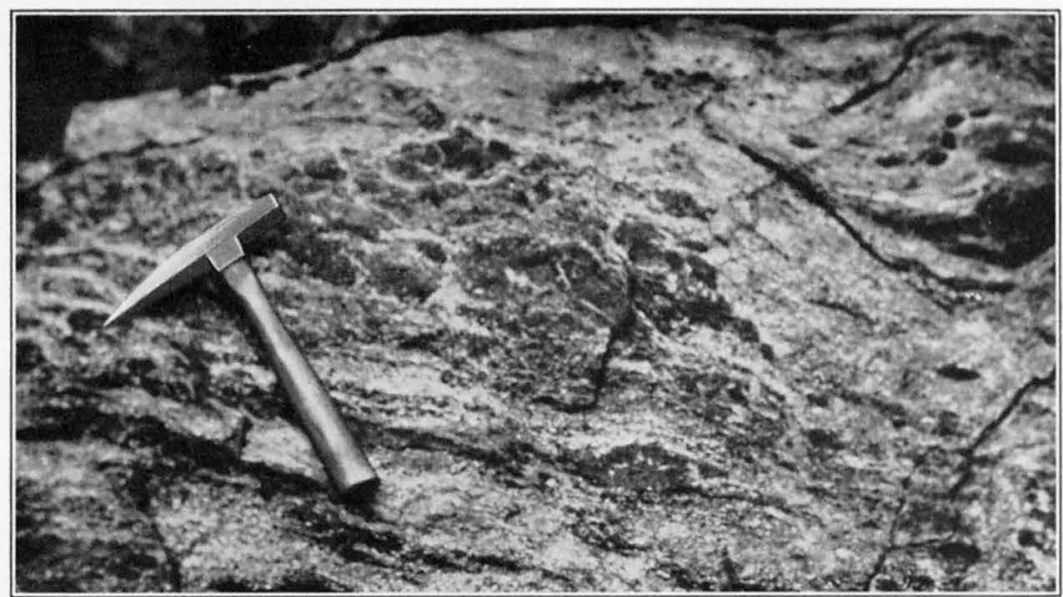

A. BRECCIATED GNEISS.

On Camas Creek.

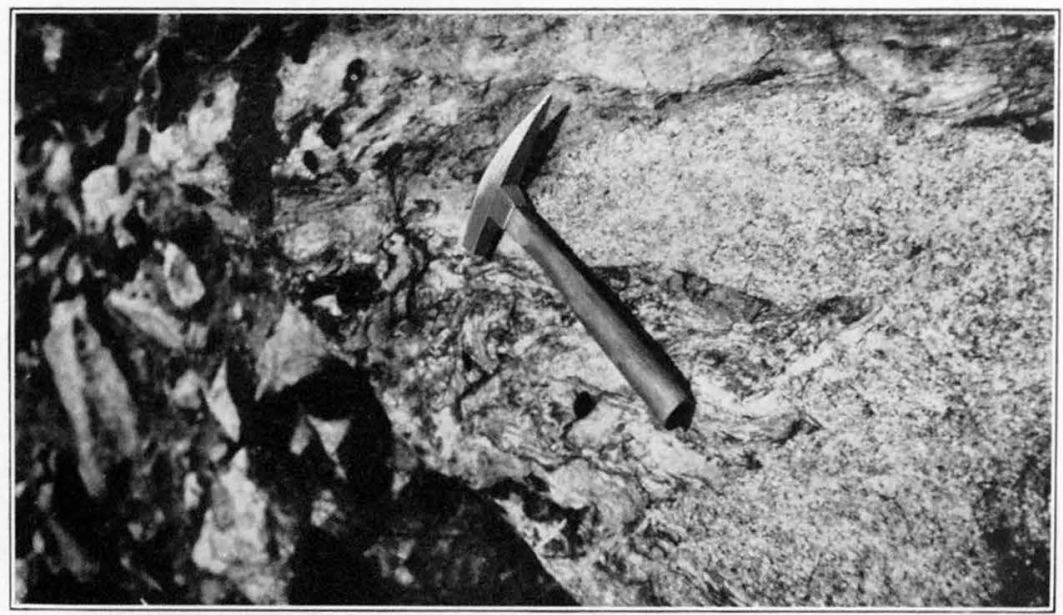

B. CONTORTED INJECTION GNEISS.

On Camas Creek. 
Some of the igneous rock in both the bands and the dikes resembles the quartz diorite, but a large part of it is pink and appears to be an aplitic facies of the nearby pinkish granite. Where the darker bands of distinct sedimentary appearance are filled with layers of this pink aplitic rock, they are also impregnated with microcline crystals (metacrysts) as much as an inch in length. Part of these crystals are rectangular and part are granulated and drawn out into lenses parallel to the bedding. Even those portions of the gneiss that superficially most resemble unaltered biotite-rich quartzite contain feldspars and other minerals whose character and interrelations indicate that they have been introduced from an igneous source. Locally there appear to be two generations of feldspars, the older more sericitized and slightly more sodic than the younger. The older plagioclase, like similar material near Yellowjacket, may have formed by recrystallization of constituents of the sedimentary rock long before and unrelated to the intrusion of the igneous rock.

Another variety, especially abundant on the south side of the principal mass and above the head of Cave Creek, is a relatively coarse-grained rock, generally pale buff to pinkish, which is overlain by and grades into nearly white quartzite. This variety differs from the dark one mainly in the comparative scarcity of dark-colored minerals, and its consequent lack of conspicuous banding gives it a more massive appearance; but fine lamination is generally present. Most of this rock contains a smaller proportion of feldspar than the dark gneiss.

A third variety of striking appearance is especially abundant on Camas Creek below Soda Creek but, wherever found, is in comparatively small masses. It consists of sharply angular fragments, rarely more than a few inches wide, of coarse-grained dark-green diorite abnormally rich in quartz in a matrix of pale, generally more or less pinkish rock of aplitic character. (See pl. 3, A.)

The greater part of the strata prior to injection were quartzitic rocks containing varying amounts of argillaceous material. The appearance and composition of the gray biotitic portions resemble those of the quartzite of the Yellowjacket formation. The pale-buff gneiss and the comparatively unaltered white quartzite on the ridge between Grouse and Camas Creeks resemble the Hoodoo quartzite. As the two gneissic rocks have stratigraphic relations corresponding to those between the two Belt formations named, it is suggested that the biotitic gneiss may correspond stratigraphically to the Yellowjacket formation and the pale gneiss and white quartzite above it to the Hoodoo quartzite.

The character of the contact between the injection gneiss and the enclosing granitic rocks varies in different places. Where small bodies of originally sedimentary rock are engulfed in the granitic rock 
the contact is gradational, and offshoots of the granitic rock intrude gneiss. The southern contact between the gneiss and the pink granite also appears gradational but is too poorly exposed to be accurately interpreted. The pink granite there is paler and more calcic than the typical rock, and the gneiss is pinker and lower in biotite. In contrast to these gradational contacts, the typical pinkish granite along the Middle Fork sweeps over the top of the injection gneiss with a perfectly sharp contact between the two. (See pl. 2, B.) The extent of the two kinds of contact is indicated diagrammatically on plate 1 , by omitting the engraved boundary line where the contact is gradational. The contact between the larger masses of gneiss and the granitic rock above the head of Cave Creek is, on the whole, sharp. Here the gneiss rests with a fairly horizontal surface on the pinkish granite.

In most places the banding in the gneiss corresponds to original bedding and is fairly constant and regular over considerable areas. Contortion is exceptional. The strike of the banding is northwest, approximately parallel to the trend of the bedding in the old sedimentary rocks elsewhere in the region. In the main gneiss area the sharp anticlinal structure of the gneiss appears to have been modified only in detail by the injection of igneous material into the beds. As can be seen from plate $2, A$, much of the injected igneous rock follows the original bedding rather closely, though not everywhere precisely. In adciition there are in places, as already stated, tongues of various sizes and kinds of igneous rock transverse to the bedding. Some of these follow clean-cut joint fractures. Others, mainly like the quartz diorite, are irregularly lobate and appear to have contorted the beds they intrude. (See pl. 3, B.) Locally, especially on Camas Creek, the bedding is so intricately crumpled where intruded by igneous rock as to suggest that the whole mass was plastic and moved like a viscous liquid at the time the structure was produced. In most such places the intruding rock is gray and resembles the quartz diorite, but in places pink rock, apparently an aplitic phase of the pinkish granite, is involved.

Origin.- The injection gneiss, according to the foregoing description, was originally a quartzitic rock that had been folded and somewhat metamorphosed prior to the intrusion of the Idaho batholith, then highly metamorphosed by injections and emanations from members of that batholith, and finally modified still further by the Miocene granite. It may well have been similar to the quartzites near Yellowjacket but is now modified by more complete recrystallization and by addition of igneous material. When the Idaho batholith was intruded there was probably a far greater amount of quartzite present than remains today in the localities where injection gneiss is exposed. 
Hence the batholith may have come to rest under a thick cover and under tremendous pressure. Conditions therefore may well have been essentially similar to those under which injection gneisses were formed farther north, in the Avery quadrangle and vicinity, where the Belt series is also invaded by granitic rocks correlated with the Idaho batholith. ${ }^{19}$ The development of injection gneiss and of gneissoid structure in the adjacent intrusive rocks, however, is not so extreme as in the Avery quadrangle and in well-known extensive areas of crystalline schists in other regions.

The more profound changes in the originally quartzitic rocks, such as intricate crumpling, recrystallization due to igneous agencies, and the intimate penetration of strata by feldspathic material, are mainly attributed to the intrusion of the Idaho batholith. Further modification by the Miocene granite, which was doubtless favored by gneissic structure already developed, will be considered after the description of the Miocene granite.

\section{AGE OF THE IDAHO BATHOLITH}

From the geologic relations observed within the Casto quadrangle it is evident that the rocks of the Idaho batholith are younger than the Casto volcanics, of Permian (?) age, and considerably older than the Challis volcanics, of Oligocene (?) age, but closer dating cannot be made. However, data bearing on this question throughout the extent of the Idaho batholith, which have recently been assembled and discussed by the writer, ${ }^{20}$ indicate that it is probably younger than Triassic and at least as old as Cretaceous. As batholiths of such magnitude are generally related to major orogenic disturbances, it is reasonable to regard this batholith as one of the products of widespread diastrophism that occurred in the Cordilleran region near the end of the Jurassic period.

\section{TERTIARY VOLCANICS (OLIGOCENE)}

Existing data on volcanic rocks of Tertiary age in this general region were summarized in a preliminary paper on ore deposits in such rocks. ${ }^{21}$ In that report the Tertiary volcanic rocks in and near the Casto quadrangle were divided roughly into three groups-a lower group of varicolored, generally silicic flows; a middle group consisting mainly of creamy tuff; and an upper group consisting largely of reddish to brownish flows containing much glassy material. These subdivisions were first recognized in the Casto quadrangle but do

\footnotetext{
10 Pardee, J. T., Geology and mineralization of the upper St. Joe River Basin, Idaho: U.S. Geol. Survey Bull. 470, pp. 49-50, 1911. Calkins, F. C., and Jones, E. L., Jr., Geology of the St. Joe-Clearwater region, Idaho: U.S. Geol. Survey Bull. 530, p. 82, 1913.

${ }^{20}$ Ross, C. P., Mesozoic and Tertiary granitic rocks in Idaho: Jour. Geology, vol. 36, no. 8, pp. 673-693, 1928.

${ }^{21}$ Ross, C. P., Ore deposits in Tertiary lava in the Salmon River Mountains, Idaho: Idaho Bur. Mines and Geology Pamphlet 25, pp. 7-9, 1927.
} 
not accord with the map units adopted here. All three of the groups originally suggested are included in the Challis volcanics as defined below. The two lower groups are so intimately related in the Casto quadrangle that they were mapped together. The representative of the original upper group in this quadrangle is mapped as the Yankee Fork rhyolite member of the Challis volcanics.

\section{CHALLIS VOLCANICS}

\section{DEFINITION AND DISTRIBUTION}

The Challis volcanics are named for the town of Challis, the county seat of Custer County, a short distance southeast of the Casto quadrangle. They comprise all the Tertiary volcanic rocks in this part of Idaho except the Snake River basalt. They differ from and are probably older than the rocks in the western part of the State commonly referred to as the Columbia River basalt. All the mineral deposits of Tertiary age yet developed in or near the Casto quadrangle are in the Challis volcanics, and probably all the similar deposits in south-central Idaho are in or related to rocks stratigraphically equivalent to this formation.

In the Casto quadrangle the Challis volcanics cover about 70 square miles in the northwestern part, nearly 135 square miles in the southeastern part, and small areas aggregating about 26 square miles in the intervening area, principally in the vicinity of Little Loon Creek. Of the total of 231 square miles, about 19 square miles is covered by the Yankee Fork rhyolite member, which is mapped and described separately.

\section{TOPOGRAPHIC EXPRESSION}

The areas underlain by the Challis volcanies are characterized by cliffs. This is especially striking in the southeastern part of the quadrangle but is noticeable wherever any considerable thickness of the formation exists. It results from the comparatively close alternation of horizontal or slightly tilted beds of contrasting hardness. The rocks, however, are not in general very resistant to weathering, and where conditions are unfavorable to cliff-making they tend to break down into talus and soil, leaving few outcrops. These materials are in general less favorable for the growth of vegetation than those derived from the other rocks in the region, and comparatively bare slopes with bright colors therefore constitute a distinctive feature of the formation.

\section{GENBRAL CHARACTER}

The flows and tuffs composing the Challis volcanics are in general of silicic to intermediate composition. Some of the tuff has been water-sorted and contains scattered pebbles small fractions of an inch in diameter, but there are no strictly sedimentary rocks in the 
formation within this quadrangle. Most of the formation here belongs to the lower group of Tertiary volcanics as defined in the paper cited above. This part is built up of a succession of generally rather bright colored flows with distinctly subordinate amounts of tuff. Nearly all of the rock in the northwestern part of the quadrangle, north of Little Loon Creek and above the head of Soda Creek, should be included in this group, and all but the upper parts of the formation elsewhere in the quadrangle also belong to it. The middle group consists dominantly of tuff but contains some flows. The flows are generally light-colored lava similar in appearance and composition to the tuff with which they are associated. Rocks of this group are well exposed on the ridge east of Little Loon Creek, in the vicinity of Little White Goat Creek, and around the head of Yankee Fork. The tuffaceous beds and the lavas interfinger wherever they are both well exposed. In many places, notably at the heads of the forks of Cottonwood Creek and in the vicinity of Parker Mountain, both lava and tuff are so abundant that no consistent subdivision between them could be made unless the mapping were refined to the extent of tracing out individual beds.

There is much variation in detail, especially in the flows, of the Challis volcanics as a whole. Several thousand flows, each a little different from the others, are exposed within the limits of the quadrangle. They appear in general to have the composition of rhyolite and quartz latite, though a few are more calcic, but most of them contain so much glassy material that their composition cannot be satisfactorily determined under the microscope. Many show flow banding distinctly. The lavas of the lower group are well represented by the two sections studied in detail and summarized in tables below. There are, however, a number of striking varieties not represented in either section. Most of these are devitrified, nonporphyritic, and generally spherulitic rocks with greenish, reddish, purplish, and other colors. The spherulites are much more irregular than in the Permian (?) lava on Sleeping Deer Mountain, and the two rocks bear little resemblance to each other. Some of the best examples of this spherulitic lava are found on the ridge south of Cougar Creek, high on the slopes southwest of Meyers Cove, and on the north side of the South Fork of Camas Creek. Translucent obsidian in small amount is associated with the spherulitic lava in places, especially north of the South Fork of Camas Creek. Both the obsidian and the spherulitic lava appear to be confined to the flows a short distance above the base of the dominantly tuffaceous part of the formation.

\section{THICKNESS}

No complete section of the Challis volcanics is exposed in the Casto quadrangle. Everywhere there are interruptions in the 
sequence by surface cover, faulting, or erosion. In several localities, however, fairly representative partial sections are exposed. Two of the most suitable of these were selected for detailed study, and the results are summarized in tabular form below. Although the rocks are broadly similar, there is little accordance in detail between the two sections. Any other section of the formation that might be studied would show similar differences in detail. Neither section includes any of the middle, dominantly tuffaceous portion of the formation. The section on Merino Creek includes all of the Challis volcanics there exposed except a few hundred feet of disturbed beds separated by canyons from those measured. The base of this section is somewhat above the base of the formation. There is much tuff in the upper part of the formation in this vicinity but not along the line of the section. The section on Camas Creek represents only part of the lower group, which is separated from the upper group in that vicinity by the alluvial terraces at Meyers Cove, beneath which the formation is probably faulted, but no better section is present in this part of the quadrangle. The lowest few hundred feet of the formation was not included because of the presence of small faults and interruption of exposures by gulches. This section is not as detailed as that on Merino Creek because exposures are not nearly as continuous, and considerable variations in the attitude of the beds, due in part to minor faulting, introduce uncertainties in the estimates of thickness. In both sections the thicknesses given are those of rock of essentially the same appearance, not of individual beds. The upper part of the Challis volcanics exposed southwest of Meyers Cove consists largely of tuff, with some rhyolite, especially in the lower part. Its total thickness is probably about 2,000 feet, although there is so much local variation in the attitude of the strata that accurate measurement was not attempted. 
Partial section of Challis volcanics along trail on Camas Creek just below Meyers Cove

[Youngest beds at top]

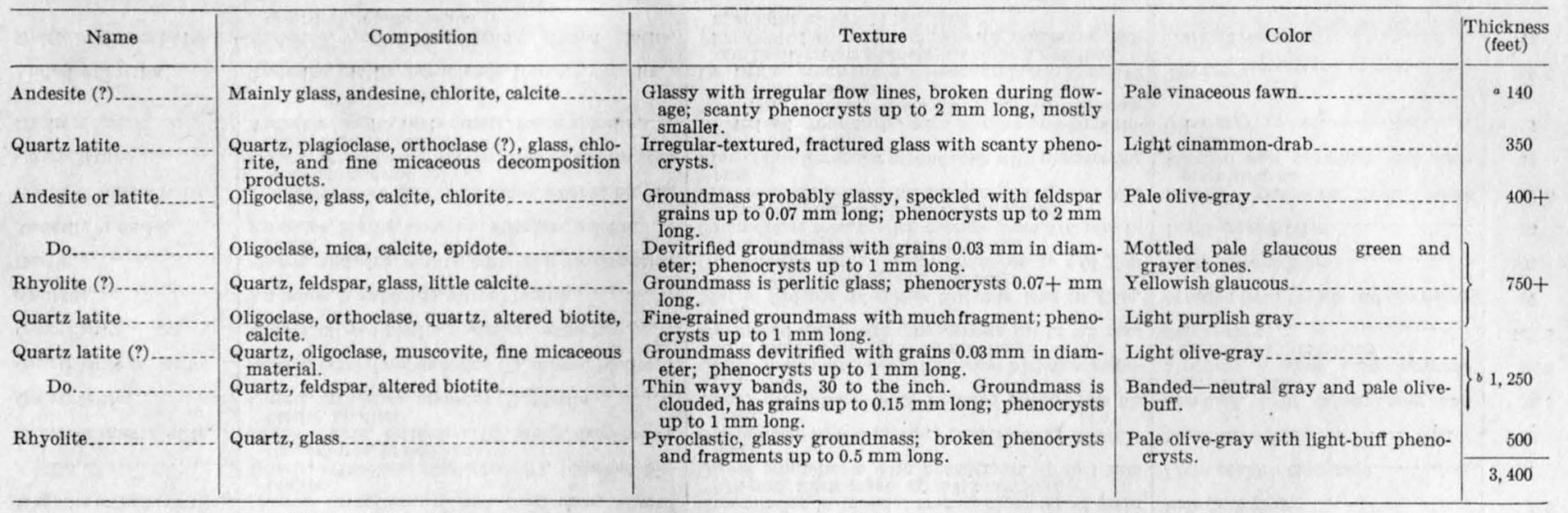

- Measured; top not included.

Attitudes not accurately known; thickness estimated. 
[Barometric altitude at base of section, 6,600 feet; at top, 8,000 feet. Youngest beds at top]

\begin{tabular}{|c|c|c|c|c|}
\hline Name & Composition & Texture & Color & $\begin{array}{l}\text { Thick- } \\
\text { ness } \\
\text { (feet) }\end{array}$ \\
\hline Andesite. & Similar to rock below.. & $\begin{array}{l}\text { Similar to rock below but coarser. Feldspar in } \\
\text { groundmass about } 0.05 \mathrm{~mm} \text { long. }\end{array}$ & Deep olive brown. & 146 \\
\hline Do. & (.................... & Similar to rock below....................... & Army brown and olive-brown, mot- & 108 \\
\hline & $\begin{array}{l}\text { Plagioclase, altered biotite, augite, chlorite, } \\
\text { epidote. }\end{array}$ & 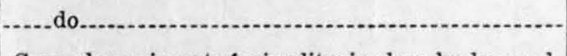 & Olive-brown with buff spots........... & 48.5 \\
\hline  & $\begin{array}{l}\text { Plagioclase (andesine?), secondary quartz, small } \\
\text { amount of altered biotite and hornblende, } \\
\text { chlorite. }\end{array}$ & $\begin{array}{l}\text { Groundmass is mat of microlites in glass, broken and } \\
\text { recemented during flowage; phenocrysts up to } 1 \\
\text { mm long. }\end{array}$ & $\begin{array}{l}\text { Olive-gray with brick-red tinge in } \\
\text { places. }\end{array}$ & 65 \\
\hline Rhyolite or quartz latite.. & $\begin{array}{l}\text { Quartz, orthoclase, altered plagioclase, altered } \\
\text { biotite. }\end{array}$ & $\begin{array}{l}\text { Groundmass in mosaic, average diameter of grain } \\
0.04 \mathrm{~mm} \text {; phenocrysts up to } 0.2 \mathrm{~mm} \text { long. }\end{array}$ & Pale drab-gray ...... & 5.5 \\
\hline Do.... & $\begin{array}{l}\text { Quartz, orthoclase, plagioclase (?), bleached bio- } \\
\text { tite, epidote, brown glass. }\end{array}$ & $\begin{array}{l}\text { Glassy groundmass with phenocrysts up to } 1 \mathrm{~mm} \\
\text { long. }\end{array}$ & Light pinkish cinnamon.. & 97 \\
\hline Dacite or quartz latite. & $\begin{array}{l}\text { Much quartz, orthoclase (?), albite, deep-brown } \\
\text { biotite, apatite. }\end{array}$ & $\begin{array}{l}\text { Groundmass largely glassy; phenocrysts up to } 1 \mathrm{~mm} \\
\text { long. }\end{array}$ & Light olive-gray..... & 200 \\
\hline Quartz latit & Quartz, orthoclase, andesine (?), biotite........... & $\begin{array}{l}\text { Glassy groundmass with rounded phenocrysts } 0.5 \\
\text { mm wide. }\end{array}$ & $\begin{array}{l}\text { Speckled, light mineral-gray and } \\
\text { cartridge-buff. }\end{array}$ & 59,5 \\
\hline Quartz latite or dacite. & Quartz, orthoclase, andesine (?), altered biotite... & $\begin{array}{l}\text { Groundmass partly devitrified glass with flow struc- } \\
\text { ture; phenocrysts up to } 0.6 \mathrm{~mm} \text { long. }\end{array}$ & $\begin{array}{l}\text { Mottled, average color approxi- } \\
\text { mately dark olive-gray. }\end{array}$ & 59.5 \\
\hline Quartz latite & Quartz, altered biotite, andesine, orthoclase... & $\begin{array}{l}\text { Devitrified glass with phenocrysts up to } 0.3 \mathrm{~mm} \\
\text { long. }\end{array}$ & Smoke-gray .................. & 125.5 \\
\hline Andesit & Andesine, hornblende, altered biotite................ & $\begin{array}{l}\text { Mat of feldspar microlites } 0.04 \mathrm{~mm} \text { long in glass, } \\
\text { with phenocrysts up to } 2 \mathrm{~mm} \text { long. }\end{array}$ & Mottled livid brown and olive-gray - & 97 \\
\hline Dacite & $\begin{array}{l}\text { Quartz, andesine, biotite, with sagenitic alteration } \\
\text { rutile. }\end{array}$ & $\begin{array}{l}\text { Groundmass partly glassy, grains up to } 0.05 \mathrm{~mm} \\
\text { wide; phenoerysts up to } 1 \mathrm{~mm} \text { long. }\end{array}$ & Light brownish drab.... & 101 \\
\hline Andesite or dac & Andesine, biotite, quartz in stringers, calcite...... & $\begin{array}{l}\text { Groundmass mosaic with average grain } 0.02 \mathrm{~mm} \text { in } \\
\text { diameter; phenocrysts up to } 2 \mathrm{~mm} \text { long. }\end{array}$ & Light-grayish olive.. & 53 \\
\hline Dacite or quartz la & $\begin{array}{l}\text { Phenocrysts are quartz, andesine, altered biotite; } \\
\text { some chlorite and calcite. }\end{array}$ & $\begin{array}{l}\text { Perlitic groundmass with phenocrysts up to } 1 \mathrm{~mm} \\
\text { long. }\end{array}$ & $\begin{array}{l}\text { Mainly vinaceous fawn. Some } \\
\text { greenish areas. }\end{array}$ & 32.5 \\
\hline Quartz latite. & $\begin{array}{l}\text { Quartz, orthoclase, oligoclase, altered biotite, iron } \\
\text { oxide, chlorite, calcite. }\end{array}$ & $\begin{array}{l}\text { Fine-grained irregular groundmass with phenocrysts } \\
\text { up to } 1 \mathrm{~mm} \text { long. }\end{array}$ & $\begin{array}{l}\text { Mottled pale olive-gray and sage- } \\
\text { green. }\end{array}$ & 14 \\
\hline Andesite or latite & $\begin{array}{l}\text { Andesine, augite, little quartz, much chlorite...... } \\
\text { Andesine, biotite, hornblende, iron ore, chlorite... }\end{array}$ & $\begin{array}{l}\text { Devitrified groundmass with angular and hypidio- } \\
\text { morphic phenocrysts } 0.2 \mathrm{~mm} \text { long; some breccia- } \\
\text { tion during flowage. } \\
\text { Devitrified groundmass, average grain less than } 0.02\end{array}$ & Olive-gray... & 59.5 \\
\hline Dacite or quartz latite. & $\begin{array}{l}\text { Andesine, quartz, hornblende, altered biotite, } \\
\text { chlorite, epidote, calcite. }\end{array}$ & $\begin{array}{l}\mathrm{mm} \text { in diameter; phenocrysts up to } 4 \mathrm{~mm} \text { long. } \\
\text { Fine devitrified groundmass with numerous feld- } \\
\text { spar laths up to } 0.14 \mathrm{~mm} \text { long. }\end{array}$ & Dark olive-gray.. & 16 \\
\hline
\end{tabular}


Latite or andesite...

Quartz latite

Do.

\section{Andesine and little altered bio
minable minerals; mostly glass.}

Quartz, orthoclase, andesine, fresh biotite, some chlorite and calcite.

Quartz, orthoclase, andesine, altered biotite and

hornblende, chlorite, and other alteration products.
Glassy groundmass with wavy intermittent banding; phenocrysts $0.4 \mathrm{~mm}$ long.

Mosaic in which average grain is about $0.07 \mathrm{~mm}$ in diameter; few phenocrysts.

Granular groundmass, average diameter of grain $0.03 \mathrm{~mm}$; phenocrysts up to $2.0 \mathrm{~mm}$ long.
Thin-banded army brown and mottled buff. Former represented only in thin section.

Pale gull-gray

Pearl-gray with greenish and reddish areas. 
The two partial sections tabulated above show that there is marked variation in the thickness of the formation at different places. Near Merino Creek the total thickness is probably less than 2,000 feet, whereas near Meyers Cove it appears to be at least 5,500 feet. In the vicinity of Parker Mountain and also near the head of Trapper Creek the total thickness, as inferred from the mapping (see pl. 1), is 5,000 feet or more. In the northwestern part of the area data for a reliable estimate are lacking, but it is clear that beds several thousand feet thick are present. In round numbers, the average thickness of the Challis volcanics within the quadrangle may be considered to be about 1 mile.

YAN KEE FORK RHYOLITE MEMBER

Definition and distribution.-Overlying the main mass of Challis volcanics in the Casto quadrangle is a rhyolitic rock of such distinctive appearance that it was separately mapped. It is well exposed in the ridges encircling the head of Yankee Fork and is therefore here named the "Yankee Fork rhyolite member of the Challis volcanics." It belongs to the upper group of Tertiary volcanic rocks described in a previous paper..$^{22}$

This rhyolite crops out over only about 19 square miles within the Casto quadrangle but covers extensive areas farther east. The largest exposures in the quadrangle are around the head of Yankee Fork and on the west side of Camas Creek south of Meyers Cove. Outliers of the masses near Yankee Fork crown some of the peaks west of Trapper Creek, and there is a mass of similar rhyolite on the ridge south of the Cougar Creek ranger station. Only strata with close petrologic similarity to that in the type localities near Yankee Fork is included in the Yankee Fork rhyolite as mapped. Somewhat similar rhyolitic flows are present in places at or near the top of the underlying part of the Challis volcanics, but these differ from it in various ways. They are of sporadic occurrence, and the total area occupied by such flows is small.

Character.-All the rocks mapped as Yankee Fork rhyolite have certain characteristics in common, but each flow differs in detail from the others. In general they are brownish rocks with a more or less distinct violet tinge. Some, especially where weathered, are lightcolored, but a few are almost black. Most of them are characterized by round, dull purplish-black phenocrysts of quartz about 1.25 millimeters in average diameter. Some have distinct flow strueture, but most do not. Many of the lower flows contain subangular fragments of the light-colored rocks below them, rarely as much as an inch in maximum dimension. These fragments, coupled with the irregularities in the lower contacts of the Yankee Fork as mapped on plate 1, indicate that an erosion interval, probably short, preceded its eruption.

${ }^{22}$ Ross, C. P., Ore deposits in Tertiary lava in the Salmon River Mountains, Idaho: Idaho Bur. Mines and Geology Pamphlet 25, p. 8, 1927. 
In most localities light-colored tuff is interbedded with the rhyolite but everywhere in decidedly minor amount. In hundreds of feet of rhyolite there may be from one to half a dozen such beds from a few feet to a few score feet in aggregate thickness.

Thickness.-Wherever the Yankee Fork rhyolite is exposed in the Casto quadrangle it is much eroded. In the vicinity of Yankee Fork less than 1,000 feet of beds remain, although it is probable that the original thickness was considerably greater. South of the Cougar Creek ranger station the maximum thickness remaining is probably only about 500 feet. West of Camas Creek the thickness is probably much less than 1,000 feet. At Castle Rock, about 21/2 miles south of Meyers Cove and a short distance outside of the quadrangle, 1,600 feet of the rhyolite with a few score feet of interbedded tuff is exposed, and the original thickness of the formation in this vicinity may have been 2,000 feet.

\section{AGE OF THE CHALLIS VOLCANICS}

Within the Casto quadrangle the Challis volcanics, like the other formations, afford no means of exact dating. Consideration of the available evidence in the region as a whole shows that they are Tertiary and probably Oligocene, or, at the youngest, early Miocene.

Structural evidence in the quadrangle proves the volcanics to be much younger than the Idaho batholith (Cretaceous or Jurassic). The complicated geomorphic history of the general region as interpreted by the writer ${ }^{23}$ shows that much time elapsed between their deposition and the first Pleistocene glaciation. They are probably much older than the basaltic flows in the Clearwater country, regarded as of upper Miocene age. ${ }^{24}$

No fossils are known in the formation in the Casto quadrangle with the exception of some indeterminate woody fragments in tuff on the ridge north of Mayfield Creek. Fossil plant remains have been found in tuffaceous beds by Umpleby ${ }^{25}$ in Lemhi Valley, Lemhi County, and by the writer and his associates at several places in Custer and Lemhi Counties. The latter have been studied by Roland W. Brown, who made some of the collectious. He concludes that, by comparison with floras elsewhere, the collections from Lemhi and Custer Counties are of upper Oligocene or early Miocene age and, from all the evidence, undoubtedly much older than the Mascall formation of the John Day Basin, Oreg., or the Latah formation of Spokane, Wash. This matter will be discussed at greater length in reports now in preparation, but for the present the Challis volcanics may be regarded as Oligocene (?).

${ }^{23}$ Ross, C. P., Erosion surfaces in Idaho-discussion: Jour. Geology, vol. 38, no. 8, pp. 643-647, 1930.

${ }^{24}$ Anderson, A. L., The geology and mineral resources of the region about Orofino, Idaho: Idaho Bur. Mines and Geology Pamphlet 34, pp. 25-26, pl. 7, 1930.

${ }_{25}$ Umpleby, J. B., Geology and ore deposits of Lemhi County, Idaho: U.S. Geol. Survey Bull. 528, pp. 38-40, 48, 1913; Some ore deposits in northwestern Custer County, Idaho: U.S. Geol. Survey Bull. 539, pp.26-27, 1913; Geology and ore deposits of the Mackay region, Idaho: U.S. Geol. Survey Prof. Paper 97, p. $35,1917$. 


\section{MINOR INTRUSIVE ROCKS RELATED TO THE CHALLIS VOLCANICS}

In a few places small bodies of igneous rock different from any known to be related to the granitic rocks intrude the Challis volcanics. One such body is mapped on the west side of Marble Creek, and small bodies are shown on the upper reaches of Duffield and Blue Lake Creeks and near the Williams prospect in the Parker Mountain district. Some of the rock east of Ibex Creek (a tributary of the East Fork of Mayfield Creek), near the mouth of the South Fork of Camas Creek, and in other localities may also be intrusive. The rock mapped west of Marble Creek is a nearly white fine-grained rhyolite porphyry. It consists essentially of quartz, alkali feldspar, and a little white mica. All the other rocks mapped are brownish, and most of them are andesite containing phenocrysts of calcic plagioclase and partly chloritized biotite. The dike near the Williams prospect and that on upper Blue Lake Creek are basalt consisting essentially of augite and labradorite. These dikes resemble some of the flows of the Challis volcanics either in this quadrangle or in neighboring areas and may be tentatively considered as of about the same age as that formation.

\section{MIOCENE INTRUSIVE ROCKS}

About a quarter of the Casto quadrangle is underlain by a large body of granite and related rock which with its associated outliers and dikes is intrusive into the lower part of the Challis volcanics and is assigned to the Miocene. These rocks are more diversified than those of the Idaho batholith, but pink granite is much the most abundant facies. The main body of granite, as shown on plate 1, forms a broad band, averaging 7 miles in width, that trends northeastward from the west-central to the northeastern part of the quadrangle, where it branches, the short eastern branch terminating near Yellowjacket and the western branch continuing northward several miles beyond the quadrangle. A small body of granite is exposed for $4 \frac{1}{2}$ miles along Loon Creek between Cottonwood Creek and Casto. The conspicuous minor members of this group, as shown on plate 1, are hornblende granite, quartz monzonite, and hornblende-quartz diorite, which are distributed for the most part along or near the margins of the main mass. Other minor variations, which grade into the granite of the main mass and have not been separately mapped, include one containing abundant micropegmatite and two varieties near quartz monzonite in composition. About 300 dikes and groups of closely spaced dikes belonging to the Miecene group have been mapped. They also are distributed for the most part near the margins of the granite masses and include white granite, quartzhornblende monzonite porphyry, dacite porphyry, andesite porphyry, pink granophyre, coarse granophyre, and lamprophyre. 


\section{PINK GRANITE}

The granite that constitutes the larger part of the main area and essentially all of the small mass northeast of Casto is pale pink and of variable but generally coarse grain. A sample of the freshest rock obtainable was taken for analysis from a blasted exposure on the trail along Loon Creek about a quarter of a mile above Bennett Creek. It is typical of the area between Powder and Cache Creeks, where the granite is more uniform and probably a little more basic than in most other areas. This sample consists of quartz ( 28 percent), microclinemicroperthite (48 percent), oligoclase-andesine (13 percent), biotite (7 percent), and hornblende (3 percent), with small amounts of magnetite and apatite. The percentages given are based mainly on microscopic measurements with slight adjustments to conform to the chemical analysis. The feldspars are slightly sericitized, and a little calcite and epidote are present in places. The microclinemicroperthite has a composition of about $\mathrm{An}_{65} \mathrm{Ab}_{35}$; its grains average 2 or 3 millimeters in diameter and have only slight tendency to crystal form. The oligoclase-andesine grains form scattered groups, compared to the biotite and hornblende, which are intergrown. The chemical analysis and norm are given below.

\section{Analysis of pink granite from Loon Creek}

[Analyst, J. G. Fairchild]

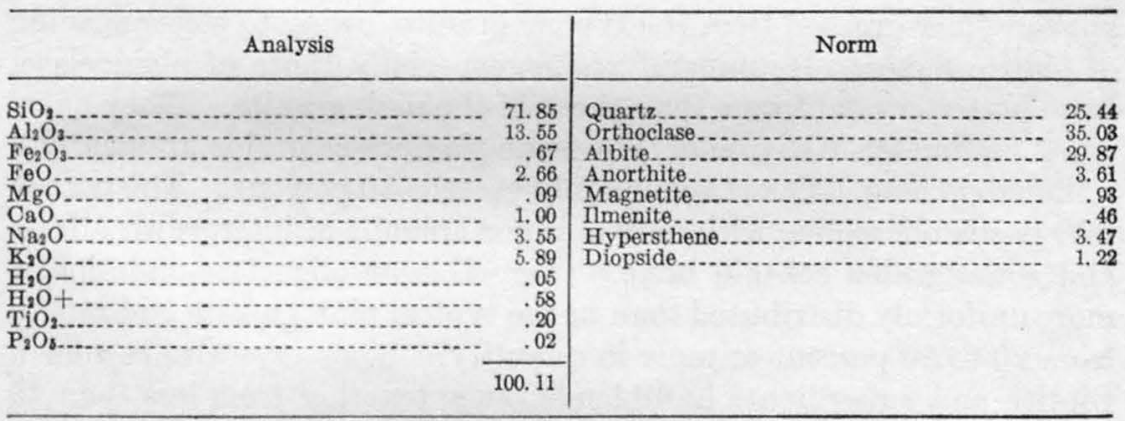

Class I, order 4, rang 1(2), subrang 3.

Many other parts of the pink granite contain more quartz than the sample just described, some nearly 50 percent; on the other hand, a few contain little more than 10 percent. Microperthite intergrowths are fully as abundant as in the sample analyzed, but the proportion of albite in them is commonly rather lower, in some places only about 10 percent. The plagioclase grains throughout the mass have a composition close to oligoclase or oligoclase-andesine. The average content of ferromagnesian minerals, especially hornblende, is probably lower than in the sample analyzed. Many specimens contain no hornblende, and some contain almost no biotite. Muscovite sheaves 
were noted in one specimen. The microperthite throughout the mass is of the kind regarded as of replacement origin. ${ }^{26}$ Small amounts of micropegmatite are present in several places.

A darker-pink fine-grained facies which grades into the type rock is composed mainly of micropegmatite. It occurs in nearly horizontal ribs, especially in the area east of the Middle Fork and north of Camas Creek. Owing to their superior resistance to erosion these ribs commonly form cliffs from 20 to 50 feet or more in height. Locally they appear to cut the typical granite. Their constituents, besides micropegmatite, are quartz, microcline, and oligoclase in phenocrysts a few millimeters wide and 5 percent or less of biotite. Here and there ferromagnesian minerals are absent. There are also in places rather small masses of coarse-grained, almost pegmatitic material surrounded by and merging into the typical granite.

A plagioclase-rich variety, which approximates quartz monzonite in composition, forms two conspicuous masses - one a broad band that extends southwestward along the west side of Woodtick Creek from a point near its mouth and continues nearly to the upper part of Cache Creek; the other around the heads of Dry Gulch and Buckhorn and Forge Creeks. It merges into the typical granite very gradually and appears to result from differentiation within the mass of the granite during consolidation. Its outcrops are light gray to nearly white, though the fresh rock has a slight pink or buff tinge. Some of it appears finer-grained than the typical granite, owing to closer spacing of biotite flakes. Its mineral grains, especially those of plagioclase, have better crystal forms than those of the pink granite. They average 1 millimeter in diameter, but some plagioclase grains are nearly 4 millimeters long. Quartz commonly exceeds 30 percent. The potash feldspar is microcline with only a minor amount of intergrown albite, and some grains contain none. Oligoclase or oligoclase-andesine is more uniformly distributed than in the typical pink granite and ranges from 20 to 30 percent or more in quantity. Some crystals are zoned. Biotite and subordinate hornblende range together from less than 10 to more than 20 percent. This variety resembles the quartz monzonite of the Idaho batholith in color but is much fresher, and its gradation into the pink granite indicates that it is part of the Miocene granite mass.

Another variety, whose structural relations have not been established, is present near lower Loon Creek in the ridges between Horse and Mearney Creeks and east of Mearney Creek. Considerable portions of it are fairly fine grained and porphyritic and contain a higher proportion of ferromagnesian minerals than the typical granite. Some of it contains enough hornblende to suggest relationship to the

${ }^{26}$ Anderson, Olaf, The genesis of some types of feldspar from granite pegmatites, reprinted from Norsk geol. tidsskrift, Bind 10, no. 1-2, 1928. 
nearby mass of hornblende granite, but it appears in places to merge into the pink granite. Detailed study might show that this variety forms a complex of dikes, but the relations, which are obscure and too intricate to be shown on plate 1 , were not worked out in detail.

\section{HORNBLENDE GRANITE AND QUARTZ MONZONITE}

The rocks in some of the smaller areas in the central and western parts of the quadrangle range from granite to quartz monzonite in mineral composition and are distinguished by the presence of hornblende. These small areas are in the upper part of the Cache Creek Basin, on and near Yellow Cat Creek, near the head of Cabin Creek, on both sides of the Middle Fork near the Cameron ranch, and on Marble Creek above the Mitchell ranch.

The hornblende granite and quartz monzonite are medium-grained and somewhat porphyritic. Where fresh they are pinkish buff, owing to the presence of pink feldspar, and are thickly specked with black hornblende and biotite; but most exposures are thoroughly rusted or bleached. The rusty appearance, together with the relative abundance of hornblende, distinguishes these rocks from all the other granitic rocks except similarly rusted parts of the quartz diorite, which is obviously richer in plagioclase and, where fresh, commonly lacks the pinkish tinge.

The least-altered quartz monzonite commonly contains oligoclaseandesine in excess of microcline, the two feldspars constituting 70 to 80 percent of the rock. Quartz constitutes 10 to 15 percent, locally more, and much of it is in micropegmatitic intergrowths with microcline. Intergrowths of hornblende and biotite also form 10 to 15 percent. Hornblende is usually the more abundant. A little apatite is commonly present, and the mass at the head of Cache Creek also contains a little zircon, tourmaline, and topaz. Much of the rock contains a larger proportion of microcline.

The small mass on Cabin Creek is the least siliceous member of the group. It contains plagioclase (45 percent), sodic microcline (32 percent), quartz (6 percent), biotite (12 percent), and hornblende (5 percent) but has more than the usual amount of micropegmatitic intergrowths, which are so very fine that their content of quartz may be underestimated. An opposite variation in composition is found at the head of Cache Creek, where sodic microcline constitutes about 6 percent of the rock.

Pyrite, some of it readily visible, is present in small quantity and is the principal alteration product. It is accompanied by sericite and some epidote, derived mainly from the feldspars, and by chlorite, derived from biotite and hornblende. Pyrite is somewhat more abundant in the area near Yellow Cat Creek than elsewhere, but even there it is sparsely disseminated. Its oxidation accounts for the rusty 
appearance of outcrops in the different areas and has led to a small amount of prospecting, but no prospects have been developed. No records of assays are available, and it is therefore not known whether sufficient gold and silver are associated with the pyrite to constitute low-grade ore that could be mined by open-cut methods. In spite of the prevalent rusty color of the outcrops, oxidation is shallow, and there is little hope of finding appreciable quantities of enriched ore close to the surface.

\section{QUARTZ-HORNBLENDE DIORTTE}

A facies of the hornblendic group that is richer in plagioclase and has the composition of quartz diorite covers two irregular areas aggregating somewhat less than 8 square miles south and southwest of Yellowjacket and nearly a square mile on and near the Castle Fork of Little Loon Creek. In the larger areas, especially on Camp Creek and near Middle Fork Peak, the rock in places is intermingled with pink granite and appears to grade into it. Whether or not there is actual gradation is difficult to determine, but it is certain that varieties intermediate in character between the two are present. The boundary between the two on plate 1 is therefore somewhat arbitrary in places.

Where fresh, the typical quartz-hornblende diorite is a nearly white, moderately coarse-grained rock spangled with numerous black grains of hornblende and biotite. In some exposures the feldspar has a slight pinkish or buff tinge, but this is nowhere conspicuous. Some of the rock, especially on Yellowjacket Creek above Hoodoo Creek, is rusty. The texture is also, in general, similar to that in the more silicic hornblendic rocks already described, except that there is no micropegmatite:

The rock contains plagioclase, potash feldspar, quartz, biotite, hornblende, minor amounts of apatite and magnetite, and such alteration products as epidote, chlorite, sericite, and calcite. In most places the plagioclase, which comprises 60 percent or more of the rock, has a composition close to andesine, but in some of the more silicic varieties it is distinctly more sodic. It is more or less sericitized. The proportion of quartz varies considerably. It is generally less than 5 percent, but in a few places it exceeds 20 percent, and in the less siliceous facies the amount is much less than 1 percent, but quartz is rarely absent. Potash feldspar is generally rare, inconspicuous, and altered. In places it is microcline, but in most specimens it is too sericitized for precise determination. In many specimens none of this mineral was noted, and in none does it exceed 10 percent. Hornblende is generally much more conspicuous than biotite, but under the microscope biotite commonly proves to be almost as abundant as hornblende. The two generally lie close together and are in part 
intergrown. Together they make up 20 to 40 percent of the rock in most places. Some of the exceptionally basic rock close to the trail high on the west side of Camp Creek contains as much as 43 percent of hornblende and 38 percent of biotite. In small schlieren that are sparsely distributed in the diorite rock on and near Yellowjacket Creek dark-green hornblende is almost the only mineral present.

\section{RELATION OF MIOCENE GRANTTE TO WAHO BATHOLITH AND
INJECTION GNEISS}

Comparison between the rocks of the Idaho batholith and those of the Miocene granitic group suggests that the conditions governing the intrusion of the two rock groups were fundamentally different. The Idaho batholith was intruded and cooled under conditions that permitted the mass to attain an essentially uniform composition and texture throughout. Also the minerals were able to crystallize as separate entities, with little tendency to intergrowth, in striking contrast to those in the pink granite. Both facts appear to imply that the body of magma was large and that intrusion and subsequent cooling were relatively slow and steady. The features of the pink granite and its monzonitic facies, on the other hand, point to comparatively rapid, irregular movement during intrusion and to cooling before adjustment could be completed. This suggests lower pressure and consequently shallower depth at the time of formation than existed when the Idaho batholith was intruded - an interpretation that is in accord with the geologic relations and probable history of the two groups of rocks.

In the description of the injection gneiss along the Middle Fork (pp. 42-45) the principal effects of injection were attributed to the Idaho batholith and some minor though striking effects to Miocene pink granite. These minor effects included tongues, dikelets, and even lit-par-lit injections of pink igneous material in the gneiss, sporadic pink pseudophenocrysts of microcline in the associated quartzite, and a second generation of microscopic plagioclase. The gneissic structure already developed is regarded as a favorable inducement for these further developments, but even so metamorphism of this kind in so recent a time as Miocene deserves a little special comment. As the Miocene granite intrusion took place when the Oligocene (?) volcanic rocks still blanketed this part of the region, the rocks now exposed along the Middle Fork near Camas Creek were at that time probably buried fully a mile below the surface. If the whole thickness of the Challis volcanics was present, the depth may have been more than 2 miles, even with due allowance for the fact that the Casto volcanics thin out northeastward in this vicinity. Loughlin ${ }^{27}$ has described somewhat similar but even more intense metamorphism in Connecticut, resulting from intrusion which he considers took place at a depth of 2 or 3 miles. This is but little in excess of the probable

n Loughlin, G. F., Gabbro and associated rocks at Preston, Conn.: U.S. Geol. Survey Bull. 492, pp. $132,133,1912$.

$$
50576-34-5
$$


depth of the injection gneiss along the Middle Fork when the Miocene granitic rocks intruded it. Some of the pink rock fills clean-cut transverse joint cracks, indicating that its intrusion continued after the injected rock had become sufficiently cooled and relieved of pressure to fracture. This is in marked contrast to the rounded outlines of the quartz diorite masses of the age of the Idaho batholith and the crumpled strata associated with them.

There are many questions regarding the process of formation of the gneiss which cannot now be answered. It is conceived that igneous material was introduced into the quartzite in two ways. One of these was the intrusion of magma, perhaps richer in mineralizers and hence more fluid than the main mass of the granitic magma but not differing greatly from it. The other was introduction into the fabric of the quartzite, especially the more argillaceous varieties, of apparently tenuous material capable of producing feldspar and other minerals generally found in igneous rocks. Such a twofold method of introduction has been recognized by Fenner ${ }^{28}$ and others. It is not necessary to assume that all the material now composing the apparently igneous minerals in the originally quartzitic rocks was introduced. Some of it may have been original sedimentary material that reacted with magmatic solutions and formed new minerals during each of the two periods of igneous activity, especially the earlier one. Possibly the chemical reactions that went on during these periods were similar to those postulated by Goldschmidt ${ }^{29}$ for gneisses in the Stavanger region. He believes that soda, silica, and potash were added to the rocks as oxides and converted into feldspars by reaction with the excess alumina already present. In this connection it may be well to point out that microcline is present in some of the argillaceous quartzite near Yellowjacket, although there is no other evidence of igneous injection in the rocks containing it. This microcline, unlike the feldspar of the injection gneiss, appears texturally to be an integral part of the quartzite, formed at the same time as the recrystallized quartz grains. Its presence suggests the existence of the components of feldspar in the original quartzite.

\section{PORPHYRIES RELATED TO THE PINK GRANTTE}

The white granite porphyry and quartz-hornblende monzonite porphyry that occur in irregular bodies near the borders of the pink granite are regarded as marginal facies of the granitic rock, although, at least in part, they are somewhat younger. In addition there is a considerable variety of fine-grained porphyritic rocks in dikes and irregular, generally small intrusive masses. These are mapped as

${ }^{28}$ Fenner, C. N., The mode of formation of certain gneisses in the Highlands of New Jersey: Jour. Geology, vol. 22, pp. 610-611, 694-702, 1914.

${ }^{20}$ Goldschmidt, V. M., Geologisch-petrographische Studien im Hochgebirge des südlichen Norwegens, V, Die Injektionsmetamorphose im Stavanger-gebiete: Videnskapsselskapets Skrifter, I, Mat.-Naturv. Klasse, 1920, no 10, Kristiania, 1921. 
dacite porphyry, pink granophyre, coarsely porphyritic granophyre, andesite porphyry, and lamprophyre. Some of these groups, especially the dacite porphyry, might be further subdivided on the basis of more detailed work, but such subdivision would be merely a matter of petrographic refinement.

\section{WHITE GRANITE PORPHYRY}

White granite porphyry is exposed at the head of Short Creek, on the upper reaches of Little Yellowjacket and Buckhorn Creeks, and above the head of Duck Creek. It weathers so readily that it is rarely well exposed, but it clearly grades into the underlying Miocene granitic rock. It is cut in places, especially on upper Short Creek, by small dikes, mainly of pink granophyre. For these reasons the exact position of the contact is here and there somewhat uncertain.

Its color is generally dirty white but locally is slightly pinkish or a little rusty. It is a fine-grained porphyritic rock, the phenocrysts attaining a length of 2 millimeters in a groundmass whose grains average about 0.05 millimeter in diameter. Its essential minerals are quartz, microcline, and oligoclase, accompanied by a little bleached and chloritized biotite and locally muscovite in almost negligible amount. Quartz amounts to as much as 35 percent and forms most of the phenocrysts. Oligoclase, as in the pink granite of the main mass, is nearly or quite as abundant as microcline. Both feldspars are somewhat sericitized.

\section{QUARTZ-HORNBLENDE-BIOTTTE MONZONITE PORPHYRY}

Quartz-hornblende-biotite monzonite porphyry has been mapped only on the spurs east of lower Woodtick Creek and at the mouth of Cottonwood Creek. Small dikes of similar rock are present in several other places but have been grouped with the more abundant granophyric rocks. It is a mottled pink and green fine-grained porphyritic rock. Phenocrysts 2 millimeters or more in maximum length constitute nearly 50 percent of it, and the groundmass is more distinctly granular than those in most of the porphyries of the Miocene group. The rock contains about 70 percent of altered feldspar, 20 percent of quartz, and 10 percent of hornblende and biotite, accompanied by a little apatite and such alteration products as sericite and epidote. The quartz is mostly in the groundmass but also forms corroded phenocrysts. The feldspar phenocrysts are so highly sericitized as to make their determination difficult. Those of oligoclase-andesine predominate, but the amount of potash feldspar is sufficient to class the rock as a quartz monzonite. Hornblende and biotite are about equally abundant and in part intergrown. The hornblende forms needlelike crystals, which help to distinguish this rock from other porphyries in the quadrangle. The groundmass 
is a mosaic in which the grains average only a few hundredths of a millimeter in diameter.

\section{DACITE PORPHYRY}

The greenish-gray rocks with felsitic groundmass and numerous white feldspar phenocrysts are grouped as dacite porphyry. There is considerable variation in details of appearance in the rocks thus grouped, and detailed study would doubtless result in subdivision. Microscopic examination, however, bears out the impression gained in the field that the resemblances are greater and more fundamental than the differences.

Rock of this group is much more abundant in the southwest quarter of the quadrangle than elsewhere but was also noted farther north. The largest exposures are those near Ivers and on Little Loon Creek. The former covers nearly $3 \frac{1}{2}$ square miles and the latter over 17 square miles within the quadrangle and probably a few square miles more farther west. Individual masses, however, are not nearly as large as is suggested by these figures. Each of the two large exposures mentioned and many of the others represent closely spaced aggregates of dikes and irregular intrusive masses, most of which are doubtless small. In most places the exposures are not good enough to make it possible to map individual bodies. One body, which happens to be well exposed, occurs on the North Fork of Sheep Creek near the west edge of the quadrangle. If exposures and time permitted, an almost infinite number of similar masses, most of them probably even smaller and more irregular, could be mapped both here and elsewhere. In several places in the general vicinity of Little Loon Creek cliff faces reveal a complex of irregular bodies of porphyry of slightly varying composition cutting one another. Near Ivers the relations between the dacite porphyry and the older rocks are intricate in the extreme, as can be judged from the description of the Lost Packer mine (pp. 120-121). Boundaries there are of necessity much generalized and are drawn with dashed lines on plate 1 . In the adjacent schist areas there are numerous dikes too small to be shown on the map, and in the area of dacite porphyry east of Ivers there are small enclosed bodies of schist. In this area, near the road, one included mass of Casto volcanics has been mapped, and the talus indicates that there are others. All such masses are certainly small and make up an insignificant fraction of the total. West of Ivers, similarly, there are included fragments of both schist and quartz monzonite in the dacite porphyry, which frays out most irregularly into the quartz monzonite.

Similar complex groups of intrusive porphyries of Miocene (?) age exist in the Wood River region. ${ }^{30}$ Here also the relations are so intricate that the mapping had to be generalized, and considerable

so Umpleby, J. B., Westgate, L. G., and Ross, C.P., Geology and ore deposits of the Wood River region, Idaho: U.S. Geol. Survey Bull, 814, pp. 57-60, 1930. 
amounts of older rocks in individually small masses are grouped with the porphyritic rocks on the map. It appears that in both regions dikes and other intrusive masses of many shapes and dimensions were intruded so abundantly and cut one another so intricately that the preexisting rock was almost obliterated, especially in the interior of the complex.

The typical dacite porphyry of the Casto quadrangle is medium gray on fresh surfaces but becomes greenish after brief exposure. Locally it is mottled with pinkish areas. It is characterized by numerous fairly well formed phenocrysts of white to pinkish feldspar and minor phenocrysts of quartz and biotite in an aphanitic groundmass, in which few grains exceed 0.02 millimeter in maximum dimension. It is considerably altered to chlorite, sericite, calcite, and epidote. The feldspar phenocrysts, which generally form over half of the rock, commonly average 2 millimeters in length but in places attain 8 millimeters. They are chiefly andesine or locally oligoclase-andesine, but orthoclase is recognized in some thin sections. Quartz rarely forms more than 10 percent of the rock. In a few of the more quartzose varieties the quartz phenocrysts are rimmed by micropegmatite. The total amount of biotite rarely exceeds 5 percent.

This rock was called diorite porphyry by Umpleby, ${ }^{31}$ but the aphanitic rather than fine-grained character of the groundmass and the constant presence of quartz give preference to the term dacite. The rock is very different from the diorite and quartz diorite of the Idaho batholith and the quartz-hornblende diorite near Yellowjacket.

A small area of somewhat darker and coarser-grained rock is exposed near the head of Brush Creek. In texture it is more nearly like a diorite porphyry than a dacite, but as it accords in structural relations and approximate age with the dacite porphyry it is, for convenience, included with that rock.

\section{ANDESITE PORPHYRY}

Andesite porphyry, exposed over nearly a square mile on the north side of Warm Spring Creek just southwest of Middle Fork Peak, is somewhat different from any other rock mapped in the quadrangle. It has a black felsitic groundmass and contains numerous moderately well formed white feldspar phenocrysts as much as 5 millimeters in length, which constitute 30 to 60 percent of the rock. There are also biotite phenocrysts so obscured by decomposition as to escape detection in the hand specimen. The rock contains nearly 90 percent of andesine, 5 to 10 percent of biotite, largely decomposed, and perhaps 5 percent of quartz in granular aggregates that may have been phenocrysts. There are also magnetite and apatite in

^ Umpleby, J. B., Some ore deposits in northwestern Custer County, Idaho: U.S. Geol. Survey Bull. 539, p. 24, 1913. 
small amount. Most of the grains in the groundmass are less than 0.05 millimeter in diameter, and they interlock in such a manner as to appear even smaller.

The rock somewhat resembles the dacite porphyry previously described, but it is darker, appears even more aphanitic, and is distinctly less siliceous.

\section{PINK GRANOPHYRE}

Pink granophyre forms several large masses, notably near Woodtick Summit and the head of White Creek, and is the most abundant dike rock throughout the quadrangle except in the southwestern part, where it is subordinate to dacite porphyry. Some of the closely spaced groups of dikes are mapped as units on plate 1. Most of the rocks included in this group are typical granophyre and distinct from those already described, but a few may be pink variations of the white granite porphyry, and a few small, irregular dikes just east of Yellowjacket resemble the quartz-hornblende diorite nearby.

The typical fresh rock is pale pinkish cinnamon-brown and weathers to buff, but some varieties have a brownish tone. It consists of phenocrysts (10 to 25 percent) of quartz, feldspar, and biotite enclosed in and corroded by an aphanitic groundmass of micropegmatite. Round phenocrysts of quartz and rectangular phenocrysts of feldspar as much as 5 millimeters in length are about equally abundant. Microcline, considerably sericitized, is commonly more abundant than plagioclase (albite-oligoclase). Biotite, partly chloritized, is scarce. The groundmass varies in detail. It is commonly a typical graphic intergrowth, but in some dikes, especially those near Yellowjacket, it consists of radial aggregates, some of which are well-defined spherulites visible even to the unaided eye.

In those dikes that resemble the white granite porphyry the groundmass consists of a mosaic of poorly defined granules. The small, irregular dikes near Yellowjacket contain considerable biotite and hornblende. Some of these contain micropegmatite, but others do not.

\section{COARSE GRANOPHYRE}

Greenish-gray granophyre, characterized by large feldspar phenocrysts in an aphanitic groundmass, is especially abundant along Trail and Loon Creeks near the Boyle ranch, and there are numerous dikes of it in the northeast and northwest corners of the quadrangle. Similar material, less coarsely porphyritic than the typical rock, is present in the saddle at the head of the North Fork of Sheep Creek near the western border of the quadrangle, where it is so intricately intruded in the dacite porphyry that the boundaries are necessarily much generalized on the map. In some places, notably on the ridge between Parker and Mahoney Creeks, small quantities of rock of this type have been mapped with the pink granophyre. 
The feldspar phenocrysts are white, pale pink, or pale gray, are fairly well formed, and in some dikes are as much as 30 millimeters long. Some have a zoned appearance due to the distribution of coloring matter. About 80 percent of them are perthitic microcline, but the microcline twinning is poorly developed in thin section, and the amount of intergrown albite is small. The remainder are oligoclase, comparatively small and somewhat altered to sericite, epidote, and calcite. Inconspicuous phenocrysts of quartz make up from 5 to 10 percent of the rock, and those of chloritized biotite are fewer. The groundmass is mainly an extremely fine granophyric intergrowth and in part a fine mosaic of quartz and feldspar, a considerable proportion of which is sodic plagioclase. The rock in general is less altered than the dacite porphyry and somewhat more so than the pink granophyre.

\section{MIOCENE (?) LAMPROPHYRE (KERSANTITE)}

Lamprophyre dikes are found in and near the pink granite at several localities. Most of them are too small to be mapped, but comparatively large exposures are shown near the Cameron ranch, west of the mouth of Duck Creek, and in a few other places. They are black and fine-grained and have biotite phenocrysts. In many dikes the mat of feldspar laths can be seen with the unaided eye. Most of them are kersantites, consisting mainly of oligoclase-andesine and partly to completely decomposed biotite, with varying amounts of apatite, black iron oxide, epidote, chlorite, and calcite. Some of them, notably one from which specimens were collected on one of the spurs west of Yellowjacket Creek, contain much more hornblende than biotite and hence may be considered camptonite.

\section{AGE AND STRUCTURAL RELATIONS OF THE PINK GRANITE AND RELATED ROCKS}

The pink granite intrudes the lower part of the Challis volcanics and hence was formed later than the beginning of their eruption. The evidence is not abundant, as the two are in contact in relatively few places. It is possible that some of the late rhyolitic flows are related to the pink granite or associated intrusions.

The intrusive character of the contact is especially well and definitely shown on the ridge between Warm Spring and Aparejo Creeks southwest of Middle Fork Peak. Plate 1 shows the broader features of the intrusive contact between the granite and the tongue of Challis volcanics that caps this ridge. In detail the contact is more intricately irregular than can be shown on so small a scale. In places the truncated ends of gently inclined flows abut against the granite. On both sides of the ridge the granite is locally finer-grained close to the contact, resembling white granite porphyry, which is a local marginal facies elsewhere. On the south side it is also rusty. Some of the lava near this rusty rock has a baked appearance and is silici- 
fied. Locally the lava has been much disturbed, as is shown by the variation in attitude of the flow-banded beds. Another bit of direct evidence is furnished by a large block of red flow-banded rhyolite, undoubtedly belonging to the Challis volcanics, which is included in typical pink granite on the spur above the Middle Fork west of White Creek. This block is roughly 30 by 45 feet in plan and has an exposed height of 20 feet. The flow banding is contorted but is on the average nearly vertical and strikes about N. $60^{\circ}$ E. Similar rhyolite forms part of the Challis volcanics that crown the ridge to the northwest.

Near the head of Jack Creek, north of the Ramey ranch, variations in the texture of the granitic rock and irregularities in its contact with the Challis volcanics suggest that it is intrusive, although the evidence is not conclusive. Similar irregularities in the contacts near the West Fork of Little Loon Creek and elsewhere seem also to be best explained by intrusion.

The smaller masses of igneous rock related to the granite, especially the granophyre dikes, are in places clearly intrusive into the lower part of the Challis volcanics, although none have been found more than a few hundred feet above the base of that formation. The close relation in time and genesis of these rocks to the main granite mass is brought out in their descriptions. Proof that some of them are younger than at least the lower part of the Challis volcanics is strong evidence that the same is true of the granite itself.

The broader structural relations of the pink granite, discussed in more detail elsewhere, have, in various respects, a bearing on the question of its age. The form of the pink-granite mass, although irregular, approximates that of a laccolith. The overlying strata were domed up rather than crosscut, which may account for the fact that the granite rarely penetrated as high as the Challis volcanics, and where it did it failed to enter them very far. At lower horizons there is abundant evidence of intrusion of the granite into the rocks of the Idaho batholith, the Casto volcanics, and older formations. The pink granite and some of the igneous rocks related to it are in several localities intruded along and hence later than faults belonging to the major fault system of the region. Faults of this system in places cut the Yankee Fork rhyolite, the youngest of the Challis volcanics (Oligocene?), so that, on this basis, the granite may be younger than all the Tertiary volcanic rocks in the quadrangle.

The hornblendic granite, quartz monzonite, and quartz diorite of the Miocene group are in most places intrusive into the pink granite, as is indicated both by the broad features of their contacts and by the detailed relations along such portions of them as are well exposed. In places along Horse Creek the relations suggest gradation into the pink granite. The small body of hornblendic quartz 
monzonite on the north side of Cache Creek is in a broad way easy to distinguish from the surrounding granite, yet in places there appears to be a gradation between them. Also some of the pink granite in this vicinity, but at a distance from the contact, contains more hornblende than usual. The quartz diorite was nowhere seen in contact with the other two hornblendic rocks, but the character and geologic relations of all three are similar. It is concluded, therefore, that the three hornblendic granitic rocks belong to the same period of intrusion as the main mass of the pink granite (Miocene) but in most places, at least, are of slightly later origin.

The seven varieties of porphyry appear to be so closely akin to the pink granite in composition and structural relations as to belong to the same period of intrusion. The andesite porphyry near Middle Fork Peak is an isolated intrusion in the pink granite and hence possibly younger than the others. The white granite porphyry is, as already stated, merely a marginal facies of the pink granite. The quartz-hornblende monzonite porphyry is cut by pink granophyre and probably was one of the earliest members of the group to form. Dacite porphyry cuts pink granite and probably the Challis volcanies also. It is cut by pink granophyre.

Most of the granophyres are near the borders of the Miocene pink granite. Mapping in greater detail would emphasize this point further, as in numerous places there are dikes too small to be shown on plate 1, and chips of granophyre in talus prove the concealed presence of still others. In the exposures along Loon Creek above Cottonwood Creek and in some other places there may be a gradation between the granophyre and the granite. In several places, especially in the northwestern part of the quadrangle, dikes of pink granophyre, mostly small, cut the Challis volcanics. Most of these are within a few hundred feet or less of the local base of the formation. On the trail between Camp and Warm Spring Creeks in the Yellowjacket Mountains there is an exposure of granophyre in the Challis volcanics that may be as much as 1,000 feet above the original base. The depth to the pink granite below this exposure is not known but may be small. These relations indicate that the pink granophyre is one of the latest of the dike rocks related to the Miocene granitic intrusion.

As the Challis volcanics, on present evidence, cannot be older than late Oligocene, the data summarized above show that the pink granite and associated intrusives must be at least as young as Miocene. The geomorphic data discussed on pages $84-86$ show that these rocks consolidated prior to the development of the Pliocene erosion surface and doubtless are materially older than that surface, which truncates structural features related to the intrusion and to the deformation of the Challis volcanics. 


\section{CONTACT METAMORPHISM}

By W. H. Newhоuse

\section{GENERAL FEATURES}

Contact metamorphism, as noted in the descriptions of sedimentary rocks, is expressed especially in calcareous rocks at widely separated places within the quadrangle. Its outstanding feature is its almost exclusive association with Miocene intrusives. Although the granitic rocks of the Idaho batholith invaded the sedimentary rocks and the Casto volcanics, even the roof pendants and inclusions of dolomite in the rocks of the Idaho batholith are little altered, though the same rock is intensely altered elsewhere. The carbonate and quartz in these roof pendants and inclusions, as in all the old sedimentary rocks of the quadrangle, have been recrystallized, it is true, and the recrystallization is correlated, in part at least, with the intrusion of the Idaho batholith; but the development of lime silicates and other typical "contact-metamorphic" minerals has been very slight. Tremolite is the only lime silicate in those dolomite masses not closely associated with Miocene (?) intrusives and may therefore be attributed to metamorphism by the Idaho batholith; but Miocene (?) dikes are so widely distributed that at no place where tremolite was noted can their influence be entirely ignored.

By far the most intense contact metamorphism has occurred in the southwestern part of the quadrangle, especially near Casto, where calcareous strata are most abundant. The metamorphosed parts of these strata are closely related to Miocene dikes, especially of dacite porphyry, which evidently served as conduits for the metamorphosing reagents. These rocks are considered in detail below.

The most notably contact-metamorphosed rock outside of the southwestern part of the quadrangle is the calcareous member of the Yellowjacket formation, which contains scapolite, a mineral not found near Casto. This rock also is intruded by Miocene dikes, but no zones of intense metamorphism like those near Casto were found associated with them.

The dark-green rock close to the peculiar masses of dolomite marble inclosed in Miocene granite along the Middle Fork may well represent intense contact metamorphism of the marble or a related calcareous rock by emanations accompanying or closely following the granite intrusion.

The fragments of dolomitic limestone on the border of the pink granite near the head of the Castle Fork of Little Loon Creek are filled with contact-metamorphic minerals. Numerous dikes of various kinds, but mainly dacite porphyry, are present here, and some of the limestone is enclosed in dike rock. No marked zones of metamorphism bordering the dike were observed, however. 
There is no noteworthy evidence of contact metamorphism in the siliceous rocks of the quadrangle, except a little local sericitization and silicification close to Miocene granitic rock.

The limestone in the areas between Ivers and the Boyle ranch, near Casto, has been replaced at several places by contact-metamorphic minerals, including small quantities of zircon, titanite, and rutile, which have formed close to dikes of dacite porphyry and coarsely porphyritic granophyre.

In some places the relations are so intimate as to leave no doubt of genetic connection between the dikes and the metamorphism; elsewhere the relations are not so close, but the character of the metamorphism is so similar as to imply a similar genesis. The dikes themselves are too small to have been the direct source of the metamorphosing emanations, but they appear to have served as conduits for the ascent of these emanations from larger masses of magma below.

One of the best examples of this metamorphism is on the point of the ridge between Canyon and Grouse Creeks a few hundred feet north of Casto. The dikes here vary somewhat in original composition, and many are altered, but most of them are coarse granophyre. Dacite porphyry is also present and is abundant a little farther north and west. Intensely altered sedimentary rock is exposed over an area of several hundred square yards. In several places in this locality zones of dark-green silicates from 1 foot to several feet wide, which have clearly replaced limestone or dolomite, are adjacent to dikes. In other places feldspathic zones are adjacent to some of the dikes. Outside of these zones the metamorphic minerals are present, but in much smaller quantity. Much of the replaced rock is described as banded hornfels. The banding results in part from a grouping of the metamorphic minerals but is due mainly to original differences in composition or in the physical character of lamellae in the limestone. The individual dikes here are all small, many having widths of less than a foot, and some of the smallest are not bordered by zones of metamorphic minerals.

At the principal flux quarry about a mile southwest of Ivers a small altered dike about 18 inches wide cuts across the quarry face. This dike is bordered by a zone in which the metamorphism was more intense than elsewhere in the quarry. Some silicate bands, similar to those of the banded hornfels, parallel this dike, but the banded hornfels at a little distance shows no relation to it. The other large flux quarry, on Deer Creek, shows similar metamorphism, but no dike is exposed.

\section{MINERALS FORMED}

The minerals characteristic of contact-metamorphic origin in sedimentary rocks more or less closely associated with Miocene dikes include spinel, olivine, phlogopite, diopside, augite, magnetite, biotite, muscovite, apatite, zircon, titanite, rutile, orthoclase, plagioclase, 
hornblende, actinolite, tourmaline, and epidote. Quartz, löllingite, pyrite, and pyrrhotite are also present but may, at least in part, have been introduced by hydrothermal action later than the contact metamorphism proper. The three metallic minerals, magnetite, titanite, and rutile, are most abundant in the flux quarries, though they may also be present elsewhere.

Spinel, which appears to correspond to the variety pleonast, occurs most abundantly with olivine and magnetite but is also associated with quartz and feldspar. Tourmaline and epidote are rare. Titanite and rutile are widespread and fairly abundant. The titanite appears to be later than the pyroxene, amphibole, and feldspar with which it occurs. The rutile is generally localized in the vicinity of biotite shreds. Some of the plagioclase is definitely albite, and some is albite-oligoclase. Feldspar is most abundant in association with quartz and biotite within a few feet of a dike. Diopside crystallized earlier than the amphibole associated with it and is most abundant close to the dikes. Olivine (chrysolite) is abundant in the zones bordering the dikes. It is everywhere partly altered to serpentine or to a mineral resembling bowlingite. Spinel, magnetite, and phlogopite are commonly associated with it. Zircon is abundant close to the dikes but is absent in the limestone at a distance from them. It apparently was formed later than the feldspar and quartz with which it is associated.

\section{CHEMICAL CHANGES}

Microscopic examination shows that in the zones in the dolomitic limestone close to the dikes there is in places an almost complete change to silicate minerals. At a distance the amount of such silicates is generally small. It is obvious that the relations cannot be explained by recrystallization of impurities in the limestone. It is necessary to assume that some elements have been added to the rock and doubtless others carried away. The amount of the change varies in different places.

In order to get some quantitative conception of the extent and character of the changes a set of representative specimens of unaltered dolomitic limestone and one of specimens of the contact-metamorphosed rock were selected from those collected at and near the principal flux quarry. Each set was crushed and quartered, and a portion of each was taken for analysis. Samples so prepared represent more nearly than individual specimens the character of the altered and unaltered rock. As the specimens composing them were collected haphazard, the samples cannot show the actual average composition of the rocks concerned, but they may represent a fairly close approxi. mation to it.

The results of analyses of the two samples and calculations based on them are tabulated on page 72 . The calculations are made so as to permit comparison between the compositions of the two samples. 
Examination of the calculations shows that there has been much silica, alumina, and iron added, while calcium oxide and carbon dioxide have been removed. Magnesium has apparently remained about constant. The increase in titanium oxide indicated by the analysis of the composite sample is so small that it would be negligible were it not that microscopic examination shows that addition of titanium has occurred locally. Zirconium was not detected in the sample of metamorphic rock analyzed, but microscopic examination shows that zircon

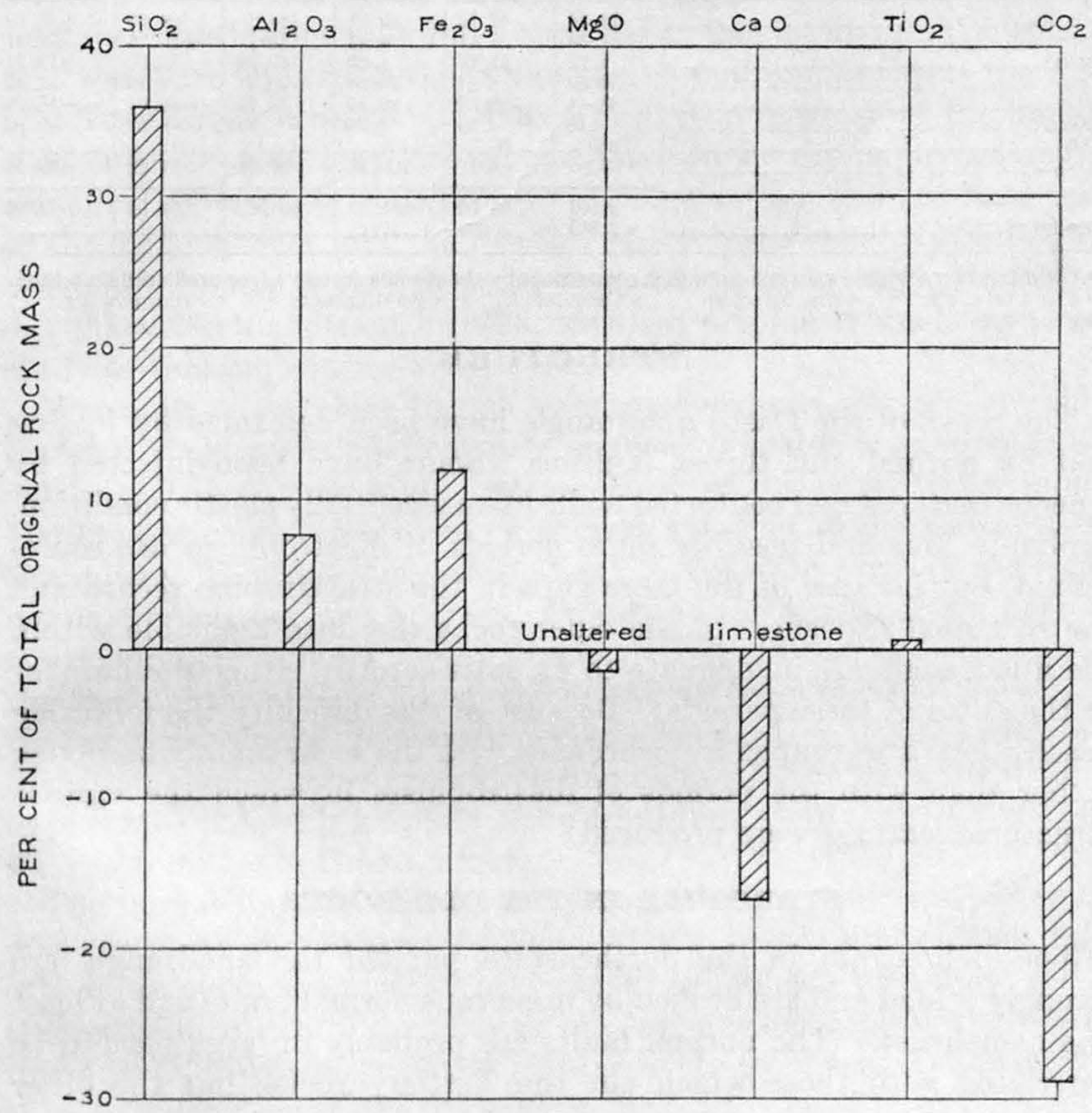

Figure 2.-Gains and losses in contact metamorphism of dolomitio limestone. Each chemical constituent is expressed in terms of percentage of mass of unaltered limestone. Vertical distances between successive lines correspond to 10 percent. Gains are above and losses below the heavy line representing the unaltered limestone.

is fairly abundant in small grains in such rock, though absent in the unaltered rock. It was evidently added during contact metamorphism but not uniformly. Zircon has lately been shown by Gillson ${ }^{32}$ to be of contact-metamorphic origin elsewhere in Idaho. The changes are shown graphically in figure 2 .

32 Gillson, J. L., Zircon, a contact-metamorphic mineral in the Pend Oreille district, Idaho: Am. Mineralogist, vol. 10, pp. 187-194, 1925. 
Analyses of unaltered and metamorphosed limestone

[Analyst, J. G. Fairchild, Feb. 26, 1927]

\begin{tabular}{|c|c|c|c|c|c|c|}
\hline & \multicolumn{2}{|c|}{ Analysis } & \multicolumn{2}{|c|}{$\begin{array}{l}\text { Constituents in } \\
100 \text { cubie centi- } \\
\text { meters (grams) }\end{array}$} & \multicolumn{2}{|c|}{$\begin{array}{l}\text { Gain or loss in } \\
\text { metamorphism of } \\
100 \text { cubic centi- } \\
\text { meters of limestone }\end{array}$} \\
\hline & $\begin{array}{l}\text { Unal- } \\
\text { tered } \\
\text { lime- } \\
\text { stone }\end{array}$ & $\begin{array}{l}\text { Meta- } \\
\text { mor- } \\
\text { phosed } \\
\text { lime- } \\
\text { stone }\end{array}$ & $\begin{array}{l}\text { Unal- } \\
\text { tered } \\
\text { lime- } \\
\text { stone }\end{array}$ & $\begin{array}{l}\text { Mets- } \\
\text { mor- } \\
\text { phosed } \\
\text { lime- } \\
\text { stone }\end{array}$ & $\begin{array}{l}\text { Grams of } \\
\text { each con- } \\
\text { stituent }\end{array}$ & $\begin{array}{l}\text { Percent } \\
\text { of total } \\
\text { original } \\
\text { rock } \\
\text { mass a }\end{array}$ \\
\hline $\begin{array}{l}\mathrm{SiO}_{2} \\
\mathrm{Al}_{2} \mathrm{O}_{3} \\
\mathrm{Fe}_{2} \mathrm{O}_{3} \mathrm{~b}^{2} \\
\mathrm{MgO} \mathrm{O} \\
\mathrm{CaO} \\
\mathrm{THO}_{2} \\
\mathrm{ZrO}_{2} \\
\mathrm{CO}_{2}\end{array}$ & $\begin{array}{r}13.84 \\
1.50 \\
1.72 \\
10.59 \\
33.44 \\
\text { Undet. } \\
\text { d } 37.82\end{array}$ & $\begin{array}{r}46.70 \\
8.11 \\
12.97 \\
8.54 \\
15.32 \\
(c) .26 \\
8.1\end{array}$ & $\begin{array}{r}39.91 \\
4.33 \\
4.96 \\
30.54 \\
96.44 \\
.288 \\
109.10\end{array}$ & $\begin{array}{r}144.6 \\
25.11 \\
40.16 \\
26.44 \\
47.43 \\
.81 \\
25.08\end{array}$ & $\begin{array}{r}+104.69 \\
+20.78 \\
+35.20 \\
-4.10 \\
-49.01 \\
+.52 \\
84.02\end{array}$ & $\begin{array}{r}+36.30 \\
+7.21 \\
+12.21 \\
-1.42 \\
-16.99 \\
+.18 \\
-29.13\end{array}$ \\
\hline Specific gravity $f \ldots$ & $\begin{array}{l}99.01 \\
2.884\end{array}$ & $\begin{array}{l}91.90 \\
3.096\end{array}$ & 285,57 & 309.63 & $\begin{array}{r}24.06 \\
\end{array}$ & $\begin{array}{r}-28.10 \\
8.36 \\
-. .\end{array}$ \\
\hline
\end{tabular}

a Calculated by dividing gain or loss for each constituent by the speciflc gravity of the unaltered limestone.

\& From total Fe. 'Not detected. ¿Calculated. By difference. / From powder.

\section{STRUCTURE}

The rocks of the Casto quadrangle have been deformed by folding and by normal and thrust faulting. Some have been injected by igneous material and contorted while in an essentially plastic condition. Probably four and possibly more periods of diastrophism are represented, but because of the large gaps in the stratigraphic record and the scattered exposures of the older rocks the data available within the quadrangle are inadequate to fix satisfactorily either the number or the dates of these periods. Because of this difficulty the following descriptions are grouped in accordance with the rocks mainly involved, rather than with the periods of diastrophism in which the various structural features were produced.

\section{STRUCTURE IN THE OLD ROCKS}

The Belt strata in the northeastern part of the quadrangle are strongly folded and are broken by numerous normal faults and at least one overthrust. The normal faults are probably in large part to be correlated with those which cut the Tertiary rocks, but the other structural features do not appear to have counterparts in rocks of postBelt age. Elsewhere in the quadrangle rocks older than the Casto volcanics are either so fragmentary or so much affected by igneous metamorphism and injection that little information regarding their structure prior to intrusion can be obtained, but their axes of folding appear similar to those in this part of the quadrangle.

\section{FOLDING}

In the 18 square miles of Belt rocks in the northeastern part of the quadrangle there is so much shattering and exposures are in places so poor that it is difficult to determine the character of the original fold- 
ing. The average strike of the folds is roughly N. $30^{\circ} \mathrm{W}$. In most places the dips are $45^{\circ}$ or less, but in numerous exposures they exceed this. On the fork of Hoodoo Creek on which the Black Eagle mine ( 2 miles north of the quadrangle) is situated the strata in several outcrops stand vertical and in places are overturned. It appears that there is an anticline between the Yellowjacket mine and Hoodoo Creek and another near Lake Creek, with a syncline between them (see pl. 1, sec. D-D'), which have been broken by later faulting. The contorted strata south of the Black Eagle mine suggest that crumpling and, perhaps, close folding may have occurred in this locality. The abnormal westward dips near the Yellowjacket mill and between the mill and Trail Creek are due either to a local flexure south of the line of section $\mathrm{D}-\mathrm{D}^{\prime}$ or to local disturbances caused by the numerous intrusions in this vicinity. In a few of the exposures along the road east of the Yellowjacket mill the relation of slaty cleavage to bedding in westward-dipping beds suggested local overturning to C. H. Behre, Jr., the writer's assistant in 1926 , who had previously made a special study of this subject. ${ }^{33}$

The only other place in the quadrangle where any considerable amount of old rocks unaffected by igneous injection is exposed is on and near Loon Creek south and southeast of the Lost Packer mine. Here the principal structure is a shallow syncline on the hill south of the mine. This syncline trends about N. $65^{\circ} \mathrm{W}$. Most of the fragments of limestone and quartzite exposed in the southwestern part of the quadrangle have somewhat similar strikes, indicating that this was the trend of the major folding which affected these rocks. The schist that underlies them, apparently unconformably, is so highly contorted that little can be learned regarding folding in it. The variation in attitude can be judged from plate 1 and from the descriptions of the Lost Packer and Monte Cristo mines.

The fragmentary and highly metamorphosed exposures of old sedimentary rocks on and near the Middle Fork, lower Camas Creek, and other streams in the vicinity also appear to indicate that these rocks before the intrusion of the granitic masses were in open folds trending roughly $\mathrm{N} .30^{\circ} \mathrm{W}$., more nearly parallel to the folds near Yellowjacket than to those near the Lost Packer mine.

\section{OVERTHRUSTING}

Between Lake and Hoodoo Creeks, especially at the head of the east fork of Lake Creek, there is evidence of the presence of an overthrust of considerable magnitude. The Hoodoo quartzite rests on the Yellowjacket formation with a nearly flat contact, sharply at variance with the attitude of the strata. The observed dips as recorded on plate 1 are $25^{\circ}$ and more, whereas the surface of contact

${ }^{3}$ Behre, C. H., Jr., Observations on structures in the slates of Northampton County, Pa.: Jour. Geology vol. 34 , no. 6, pp. 481-506, 1026. 
has in general an inclination of less than $10^{\circ}$. On the east fork of Lake Creek steeply dipping strata are exposed both above and below the contact in a way that can be explained only on the basis of rupture and movement. The attitude of the strata here varies in almost every exposure, testifying to considerable local disturbance. The Hoodoo quartzite between Hoodoo Creek and the west side of Lake Creek is flexed into a broad anticline, which does not appear to accord with any of the other folds exposed in this part of the region. The nearly pure quartzite of this formation appears to have been brittle under the stresses to which it was subjected, for many exposures in this locality show intense fracturing, which is not characteristic of the same rock in most of the outcrops seen in the surrounding region. In exposed places on the ridge between Lake and Hoodoo Creeks outcrops are absent or small and the ground is littered with angular pieces of quartzite, which have been weathered out of the fractured rock. On this ridge white quartzite is exposed which appears to be commensurate in thickness with the Hoodoo quartzite in the measured section on Yellowjacket Creek. On the east fork of Lake Creek the base of the formation is exposed, as is shown by the gray beds resembling the quartzite of the Yellowjacket formation interbedded with typical white Hoodoo quartzite. In places on the east side of the basin at the head of this fork the plane of fracture appears to lie below the base of the Hoodoo quartzite and cut the upper beds of the Yellowjacket formation.

The data above set forth show extensive and powerful fracturing along an undulating surface of such low inclination as to indicate overthrusting of considerable magnitude. The fact that the overriding block contains an anticline that is unlike the other folds within the area mapped also suggests that it was brought from a distance. It happens that in the small area studied the overriding block is composed of younger rocks than those beneath the thrust surface. Opposite relations may exist elsewhere, but investigations must be carried farther north or east before the extent and character of the overthrust can be satisfactorily determined.

No overthrusting or overturning is known elsewhere in the quadrangle, although evidence of such action is abundant in the Belt rocks at other places in this part of Idaho.

\section{NORMAL FAULTENG}

Many of the exposures of the old rocks throughout the quadrangle show slickensides, fracture zones, and other evidences of faulting. With the exception of the thrust near Lake Creek it is probable that all the faults are normal. Where the dip of a fault plane can be determined it is so nearly vertical that reverse faulting is improbable, and in some places, as at the head of Lake Creek, normal displacement can be observed. 
Most of the normal faults involving old rocks are so small or so poorly marked as to escape record on plate 1 . There are probably several faults south of Ivers sufficiently large to complicate and obscure the interpretation of the stratigraphic succession in the sedimentary rocks. Exposures in this vicinity are so poor that precise data were not obtained. The numerous small faults in the Lost Packer mine are discussed in the description of that mine.

The largest normal faults involving old rocks are those in the northeast corner of the quadrangle. Seven of the more prominent ones are plotted on plate 1 , and more undoubtedly exist, as is shown in mine workings and other places where exposures are good. Part of this faulting is probably genetically related to the overthrusting in this part of the region, but part of it is clearly younger, as two of the faults plotted displace the Challis volcanics. The mass of these volcanics on the ridge near the Columbia mine is probably also faulted, although data on which to plot definite faults were not obtained. These younger faults are probably to be correlated with the strong system of faults that cuts the volcanic rocks elsewhere in the quadrangle (pp. 77-78.)

The two faults west of the Yellowjacket mine appear to be much the largest normal faults in this part of the quadrangle. The one that trends N. $25^{\circ} \mathrm{E}$. is especially well marked. It can be readily traced by evidence of brecciation and slickensiding, even near its south end, where the rocks on both sides are dark slaty quartzite belonging to the Yellowjacket formation. The dip of both faults appears to be steep, perhaps even steeper than is indicated on plate 1 , section $\mathrm{A}-\mathrm{A}^{\prime}$. Their throws cannot be determined from the data at hand. If the wedge of Hoodoo quartzite between these faults has been derived from a mass of the Hoodoo quartzite arching over the Yellowjacket formation in normal sequence the displacement must be several thousand feet. It seems more probable that the overthrust block exposed near Lake Creek originally extended this far east and that the wedge of Hoodoo quartzite is a part of it. If so, the displacement on the normal faults may not exceed a few hundred feet. There is no direet evidence for correlating these two faults either with those related to overthrusting or with those of late Tertiary age.

\section{FOLDS IN THE CASTO VOLCANICS}

The Casto volcanics are both folded and faulted, but the faults are so closely akin to those in the Tertiary volcanic formations that they are most conveniently discussed under that head. The details of both faulting and folding in the Casto volcanics are difficult to determine, because in many exposures the attitude of the bedding cannot be discovered, but the major features of the structure are clear. Dips are in general moderate, and there is no suggestion of 
crumpling or overturning. It appears that the stresses which acted on these rocks were far less intense and powerful than those which affected the Belt and early Paleozoic strata.

In the southern part of the quadrangle the Casto volcanics are bent into open folds striking $\mathrm{N} .55^{\circ}-75^{\circ} \mathrm{E}$, with local variations outside these limits. The dip ranges from a few degrees to nearly vertical, but over much of the area it is from $25^{\circ}$ to $50^{\circ}$. The character of the folding is illustrated in plate 1 , sections $\mathrm{B}-\mathrm{B}^{\prime}$ and $\mathrm{C}-\mathrm{C}^{\prime}$.

In the northern part of the quadrangle the beds are more massive, and fewer direct measurements of strike and dip can be made. The average strike is about the same as farther south, and the dip, except in the vicinity of faults, rarely exceeds $30^{\circ}$. The Casto volcanics, like the overlying Challis volcanics, are gently domed over the Miocene granite. This dome appears to be the major structural feature in these rocks in the northern part of the quadrangle, although there are numerous faults and smaller flexures.

\section{STRUCTURAL RELATIONS OF THE ROCKS OF THE IDAHO BATHOLITH}

As previously shown, a large part of the granitic rocks of the age of the Idaho batholith in the Casto quadrangle are in contact with younger rocks, some of which are intrusive and in many places have very irregular contacts, and others are effusive or sedimentary and lie unconformably upon the batholith. On the ridges on both sides of the upper part of Little Loon Creek and on that north of the East Fork of Mayfield Creek quartz monzonite of this batholith immediately underlying the Challis volcanics is more weathered than elsewhere. This suggests that there was greater opportunity for weathering in the period immediately prior to the eruption of the Challis volcanics than there has been in recent times.

The quartz monzonite cuts sharply into the older stratified rocks, with generally steep contacts, and in numerous places encloses blocks of them. Some of the blocks that were partly or completely engulfed in the magma have dimensions measurable in miles. The comparatively flat lower contact of the Casto volcanics on the north side of the main fork of Mayfield Creek suggests that this is a piece of the roof into which the magma did not cut deeply, but among exposures now remaining this is exceptional. Available evidence indicates that the quartz monzonite of the Idaho batholith was introduced in the manner common to large batholithic intrusions, causing or accompanying regional uplift, but the striking feature of its observable relations is its ability to transgress and shatter the rock with which it came into contact. So far as present data indicate, the areal dimensions of the batholith increase downward. There is no known evidence, either here or elsewhere in the region, of the existence of a lower surface of the quartz monzonite. 


\section{STRUCTURE OF TERTIARY ROCKS}

FOLDING

The Tertiary volcanics have been bent into broad folds that strike northeast. The major flexure is a broad dome or arch, which extends far beyond the limits of the Casto quadrangle. Its longer axis trends about $\mathrm{N} .40^{\circ} \mathrm{E}$. and in the central part of the quadrangle lies approximately along the Middle Fork of Salmon River. Reconnaissance studies outside the quadrangle indicate that, in a broad way, its flanks slope northwestward past the Thunder Mountain district and southeastward past Challis. The Tertiary rocks are largely eroded away at both ends of the main axis, and little geologic work has yet been done in these parts of the region, so that the closure of this great fold is not known, but it clearly covers an area of more than 3,500 square miles. The southeast flank had an original average dip of not much over $5^{\circ}$, and the northwest flank was even more gently inclined.

The broad arch is modified by subordinate flexures, in part transverse, and has partly collapsed, with the formation of numerous normal faults. The largest of these subordinate flexures are near Meyers Cove and northeast of Parker Mountain, and each extends over several square miles. Within these and smaller flexures the strike is within $20^{\circ}$ of east and the dip generally $45^{\circ}$ or more. Locally, both within these flexures and elsewhere, abnormally steep dips are attributed to faulting. The faulting may well have proceeded concomitantly with the folding and prevented the full development of the arch. Much remains to be learned about these minor structural features, especially outside the limits of the quadrangle, and therefore the main arch cannot now be accurately reconstructed.

The main arch is evidently related to the intrusion of the Tertiary granite and hence is probably of Miocene age. The minor flexures were doubtless products of the same period of diastrophism. Some may have been formed earlier than the main arch. It is clear from the geomorphology that the uplift which began with the production of the arch has continued intermittently up to recent times. The total uplift from the Micoene to the present is probably of the order of 5,000 feet. As the evidence of recent uplift is geomorphic rather than structural it will be discussed under "Geomorphology."

\section{FAULTTNG}

Normal faults of Tertiary age, many of them with large displacements, form one of the striking structural features of the Casto quadrangle. Some of them are wholly within areas of Casto volcanics, but as they are similar to or identical in detail with those that cut the Challis volcanics, there is no reasonable doubt regarding their age. Most of these faults fall into two groups. Those of the larger and 
better-developed group have an average trend of about N. $37^{\circ} \mathrm{E}$. Most of the observed faults in this group trend within $10^{\circ}$ of this average, and a few trend more than $15^{\circ}$ away from it. The faults of the smaller group have an average trend of N. $27^{\circ}$ W., and few of them deviate as much as $10^{\circ}$ from this average. The most conspicuous exceptions to this grouping are the two faults near the East Fork of Mayfield Creek, which trend nearly east.

Exposures of fault planes in either group are rare, and most of those seen represent minor movements too small to be shown on plate 1 . The most useful indications of the faulting are the abrupt terminations of rock masses and the contacts that do not accord with the attitude of the strata involved. Brecciation and rapid variation in strike and dip are also significant. In a few places fault breccia in which angular fragments of widely different sizes have been recemented by silica and iron oxide stands up in relief like a wall or dike and can be easily traced. The best example of such a breccia and the only one that is exposed continuously for more than a mile is that near the crest of the mountain south-southwest of Meyers Cove, near the lower contact of the Yankee Fork rhyolite. Along a number of the faults that involve either the Casto or the Challis volcanics sufficient hematite impregnates the wall rock and coats fracture surfaces to produce a dark-red zone from a few inches to a few feet wide. Where such hematite stains are noted faults may be inferred, even though other indications are lacking.

Some of the faults, especially the larger ones, are in or approximately parallel to stream valleys, especially those of northeast trend. Several other valleys have similar trends and may well be associated with concealed faults or shear zones.

\section{FAULTS OF NORTHEAST TREND}

Faults of the larger northeastward-trending group have the larger average throw and are the more easily recognized and mapped. As can be seen from the sections on plate 1 the faults of this group dip both northwest and southeast, generally at high angles. Most of the slickensided surfaces noted are inclined at $80^{\circ}$ or more. The lowest dip measured is $59^{\circ}$, on a small fault on Camas Creek near Meyers Cove. The slickensides are not necessarily parallel to the major movements, but they furnish the only opportunity for direct measurement. The fault traces as mapped are so nearly straight, in spite of the rough topography, as to corroborate the conception of steep dips conveyed by the observed attitudes of the slickensided surfaces.

Direct measurement of the amount of displacement is difficult because of the lack of reliable horizon markers, but that along some 
of the faults is clearly very large-for example, the rocks forming the summits of Parker Mountain and neighboring peaks belong stratigraphically not far below the Yankee Fork rhyolite, yet their average dip if projected southeastward would carry them more than 6,000 feet below the base of the Yankee Fork rhyolite in the mountains to the southeast, beyond Warm Spring Creek. This discrepancy doubtless indicates the order of magnitude of the faulting along and near this part of Warm Spring Creek. The relations, so far as known, are shown in plate 1 , section $\mathrm{B}-\mathrm{B}^{\prime}$. Only one fault in this zone was observed, but there are doubtless others parallel to it, and the total displacement indicated above is the aggregate for the zone. Exposures in the tributary valley containing the exposed fault show conclusively that this is not a single break, as is diagrammatically indicated on plate 1 , but a fault zone of considerable width. Along Warm Spring Creek itself local brecciation suggests the probability of faulting, as indicated on plate 1, although no major break was exposed.

Some of the numerous faults in the vicinity of Warm Spring Creek farther west have displacements almost as large as that of the fault zone along the upper part of that stream. Some of those near Parker Creek, as is indicated on plate 1 , section $\mathrm{B}-\mathrm{B}^{\prime}$, must have displacements of well over 2,000 feet, and several other faults are nearly or quite as large. The series of faults from Loon Creek near the mouth of Warm Spring Creek to a point above Parker Creek appear to mark an area of profound fracture in the great arch previously described. The area affected by the subsidence is surely as much as 100 square miles and possibly much greater. The base of the Challis volcanics at its lowest place, directly beneath Snowshoe Creek, is roughly 10,000 feet lower than it would have been if the arch had developed without breaking; but if, as already suggested, uplift and fracture went hand in hand, the rocks near Snowshoe Creek were never lifted 10,000 feet above their present position.

The faulting near Sleeping Deer Mountain, which brought small blocks of Challis volcanics down so far that they have not yet been eroded away, probably indicates fracture of the arch similar to that just described but of less magnitude. The relative subsidence below the theoretical position of the completed arch may have been about 1,000 to 2,000 feet, but the actual displacement on any one of the faults is probably much smaller. The strata of the Casto volcanics in this vicinity belong to the upper part of that formation, and part of the main mass of the Challis volcanies slopes up from the vicinity of Meyers Cove to altitudes similar to those at which the fault blocks are exposed. These facts indicate that the displacements are not large, but the available data do not permit measurements. There are more faults in this locality than have been plotted. 
The blocks of Challis volcanics north of Falconberry Lake have been thoroughly shattered, considerable parts of them containing few unbroken masses as much as a rod wide. This shattering is in part irregular and in part expressed by closely spaced sheeting parallel to the bounding faults of northeast trend. The sheeting is well illustrated at the north end of the northernmost group of fault blocks on the south side of Cache Creek. This group terminates in a series of cliffs made up of a rapid alternation of Casto and Challis volcanics. Some of these fault slivers are only a few feet wide. They are so closely spaced that only the boundary faults are shown on plate 1 . The Casto volcanics in the area between Falconberry Lake and Sleeping Deer Mountain vary notably in attitude within short distances and in places exhibit the brecciation and red stain which in this region are associated with faulting in the volcanic rocks.

In the western part of the quadrangle faults of northeast trend seem less common and are probably of smaller average displacement than those in the eastern part. A fairly large fault that has been mapped on the southeast side of Little Loon Creek west of Castle Fork may have a displacement as great as 3,000 feet. Interpretation of the structure here is complicated by the presence of numerous intrusive masses, which appear to be later than the faulting. The faults north of the Middle Fork near Ramey Hill and White Creek may also have had considerable displacement. These faults, especially the more northerly one, at the head of White Creek, caused strong brecciation and are marked in places by much red stain. The Tertiary granite appears to be later than this fault. Smaller faults of northeast trend have been noted in the western part of the quadrangle. It seems likely that some faults in this part of the quadrangle have been so healed by later intrusion as to escape detection. For example, the block of Casto volcanics on the west side of Loon Creek north of Bear Creek is now surrounded by igneous rocks that clearly intrude it, but the block may originally have been brought into approximately its present position by faulting.

\section{FAULTS OF NORTHWEST TREND}

The faults of northwest trend are less than half as numerous and on the average are smaller than those of northeast trend. Unlike the northeast faults, they appear to be more numerous in the western part of the quadrangle than in the eastern part. Several have been mapped in the mass of Challis volcanics that occupies the northwestern part of the quadrangle, and there are others in this area that are either too small to map or have not been traced out in detail. The numerous faults of this group that are mapped somewhat diagrammatically in the vicinity of Shellrock Peaks doubtless have their counterparts elsewhere in localities where exposures are 
not so good. Individual northwest faults in this part of the quadrangle probably have displacements of a few score or at most a few hundred feet. A few faults of nearly northerly trend have been noted here, but so far as known these are neither abundant nor of large displacement.

The northwestward-trending fault along Warm Spring Creek near the mouth of Parker Creek appears to have sufficient lateral shift to move the rocks on the right side of the creek about 1,000 feet farther northwest than those on the left wide. The vertical component of the displacement may be of about the same magnitude. Several other faults of northwest trend are shown on plate 1. Among these may be mentioned the one on Camas Creek near Meyers Cove and several west of Yellowjacket.

The two sets of faults appear to be complementary and to form parts of a fracture system which is widespread in south-central Idaho, recording relief of tensional stresses doubtless related to the Tertiary igneous activity. Similar faults have been mapped in the Wood River region ${ }^{34}$ and elsewhere. In some localities the faults of northwest trend are more abundant than those of northeast trend, and even in some localities where the reverse appears true, as in the Wood River region, the northwesterly faults are nevertheless longer and probably of greater displacement. Predominance of one set of faults over the other varies with local conditions.

\section{STRUCTURAL RELATIONS OF THE MIOCENE GRANITIC ROCKS}

The main mass of pink granite has a roughly domelike upper contact, although its contacts are irregular in detail, and it may even have a sill-like or laccolithic form. Its contacts dip, with few local exceptions, at very low angles away from its major axis, which roughly coincides with the course of the Middle Fork and with the axis of the main arch of the region. A base to the granite mass is suggested by the presence of older rocks along the Middle Fork in the north-central and western parts of the quadrangle. (See pl. 1, sec. $\mathbf{C}-\mathrm{C}^{\prime}$.) West of Little Loon Creek the Tertiary granite clearly overlies the older rocks, which thus form, locally at least, a somewhat irregular floor to the intrusive mass. Near Camas Creek the pre-Tertiary rocks as now exposed have a relief of nearly 6,000 feet, but the Miocene granite appears everywhere to overlap them. This relation is particularly evident on the map near the mouths of Yellowjacket and Woodtick Creeks. The injection gneiss and associated igneous rock in this vicinity apparently mark a relatively large upward projection in the irregular floor of the Miocene granite.

\footnotetext{
3 Umpleby, J. B., Westgate, L. G., and Ross, C. P., Geology and ore deposits of the Wood River region. Idaho: U.S. Geol. Survey Bull. 814, pp. 69-73, 1930.
} 
This evidence is admittedly scant and is weakened by the irregularity of the contacts, but so far as it goes it indicates that the granite magma rose along comparatively small conduits and spread horizontally after reaching the horizon of the Casto voleanics.

The principal irregularity in the generally domelike form of the upper contact is in the vicinity of Two Point and Shellrock Peaks, near the northwest corner of the quadrangle. There the contact slopes upward to the northwest, and the structural relations as a whole indicate a subordinate dome, somewhat modified by faulting, which extends beyond the limits of the quadrangle. (See pl. 1, sec. $\mathrm{A}-\mathrm{A}^{\prime}$.)

The relation of the Miocene intrusives to the Tertiary faults has already been mentioned. Faults formed prior to the termination of intrusive activity served as conduits, not only for dikes and small outlying masses but for extensions of the main mass. The two faults near Ramey Hill are examples. Near each of the main fault contacts the granite has penetrated into volcanic formations and has evidently followed zones of weakness. Both the Casto and Challis volcanics are fractured, slickensided, and locally stained with hematite along these faults, but the granite shows no such evidence of disturbance. Inspection of plate 1 will show other places where the trend of the granite contact is similarly related to faulting.

The one place where the pink granite of the main mass sharply transgresses the overlying rock on a large scale is along a line from the head of Woodtick Creek northeast across Camas Creek. The line of contact here is closely parallel to the trend of the major fault system, and there is some evidence of minor faulting near it; but on the whole the contact is intrusive and may be inferred to have followed one or more Tertiary fault zones. Subordinate intrusions are exposed at intervals along the contact and may have been localized by renewed movements along this zone of weakness.

The only large mass of pink granite detached from the main mass is that with a northeasterly trend on Loon Creek. This lies in the southwestern prolongation of a zone of fracture marked by discordance in the character and attitude of the strata on opposite sides of Loon Creek and by hot springs. The granite itself is free from deformation and hence is believed to be of later date. The accordance of the trends of the granite and some of the granophyric dikes with that of the faulting indicates that the intrusions came in along zones weakened by the faulting.

Near the mouth of Parker Creek, where pink granophyre and hornblende granite are present in the fault zone, dikes of the granophyre cut across one of the faults without being displaced or appreciably fractured. At many other places in the quadrangle dikes of granophyre and related rocks are elongated parallel to the northeast fault system, and some are parallel to the northwest system. 
The intrusion of the pink granite and associated rocks is thus closely related in time and genesis to Tertiary folding and faulting, but the quadrangle is too small an area to afford evidence for determining whether the force of the intrusion induced the folding and faulting or took advantage of structural features already produced by regional compression. It is quite conceivable that magma rising along this zone and spreading from it could develop the broad, low arch in volcanic formations, that the arch would break and develop longitudinal and transverse faults, and that the still fluid portions of the magma would follow the openings afforded by the faults. This matter will be further treated in a report covering all of south-central Idaho, now in preparation.

\section{GEOMORPHOLOGY}

Much has been written about the geomorphology of central Idaho, especially about the summit peneplain of the region,,$^{35}$ but detailed studies are lacking, largely because of the absence of adequate base maps. The present study shows that the geomorphic history has been even more complex than might be inferred from previous descriptions and probably is comparable in this respect with that of southeastern Idaho as worked out by Mansfield ${ }^{36}$ and his associates. In the Casto quadrangle an early Tertiary erosion surface has been buried under Oligocene (?) volcanic rocks, and the postmature surface developed across the volcanics in later Tertiary time has since been greatly dissected in a series of incomplete erosion cycles, coupled with at least two glacial stages.

\section{OLD TERTIARY EROSION SURFACE}

The oldest erosion surface of which any considerable remnants are preserved in the Casto quadrangle is that on which the Challis volcanics (Oligocene?) were laid down. As only a minor part of the quadrangle is not now covered with Tertiary rocks, and as all of it was warped and broken in Miocene time, evidence regarding this old surface must be obtained mainly from study of the lower contact of the Challis volcanics. This contact, where exposed, is in general remarkably even and regular. Only here and there, as on the ridge northeast of the Boyle ranch, are irregularities visible which did not result from post-Eocene structural disturbances. Few if any remnants of this old surface form parts of the present topography, however, and parts of it that are still covered by the Challis volcanics are decidedly irregular, varying more than 2,000 feet in altitude, mainly as a result of deformation subsequent to the deposition of the Challis volcanics.

as Mansfield, G. R., Tertiary planation in Idaho: Jour. Geology, vol. 32, no. 6, pp. 772-797, 1927.

so Mansfield, G. R., Geography and geology of southeastern Idaho: U.S. Geol. Survey Prof. Paper 152, pp. 8-19, 1927. 
No conglomerate has been noted in the Challis volcanics in this quadrangle, indicating that the topography may have been so gentle that the streams were not transporting gravel. Elsewhere in central Idaho, however, the Challis volcanics contain conglomerate, as in the Thunder Mountain district, Valley County, and in the so-called "lake beds" in Lemhi Valley, Lemhi County. Near the head of Monumental Creek, nearly 10 miles southwest of Thunder Mountain, and in the Vienna district, Blaine County, ${ }^{37}$ tuffaceous conglomerate containing pebbles of the underlying granite forms the base of Tertiary lava flows. In all these localities, especially on Monumental Creek, the surface on which the conglomerate rests is irregular. The probable existence of rugged topography in pre-lava time in the Lemhi Range has been pointed out. ${ }^{38}$ These facts suggest that elsewhere in the general region the topography at the beginning of Oligocene (?) volcanism was more rugged than it was in the Casto quadrangle. Like most other topographic features, this old surface doubtless had a complex origin, and much time was required for its formation. The region was exposed to subaerial erosion at least from the late Mesozoic to the time of its mantling by Oligocene (?) lava and tuff.

\section{LATE TERTIARY EROSION SURFACE}

There is not sufficient accord in altitude or flattening of the tops of the highest peaks in the quadrangle to imply the existence of a summit peneplain, but long, narrow, comparatively even-topped ridges several hundred feet below the peaks are among the most striking and widespread features of the topography - a fact which would be more clearly shown if plate 1 were on a larger scale. Some of these ridge tops are narrow and rocky, but others are forest-covered and so nearly level that the conception that they are fragments of a formerly more extensive surface of rather low relief seems to be the only logical one. The contrast between their gently rolling topography and the almost precipitous slopes that bound them could hardly have been brought about in any other way. One of the most characteristic of the smooth level-topped ridges is shown in plate $4, A$. They are not in general accord with rock structure and are clearly products of erosion. The formations underlying them range from the Yankee Fork rhyolite to the Belt quartzites, which in places are steeply inclined. Some of the peaks that rise above them, like Sheldon and Sherman Peaks, doubtless owe their preservation to the fact that they are composed of relatively resistant Yankee Fork rhyolite resting on tuff. Others, like Pinyon Peak, are merely the unreduced parts of masses of resistant rock. A few, such as Twin Peaks, just beyond the southeast edge of the quadrangle, are composed largely of tuff. The widespread

\footnotetext{
37 Ross C. P., The Vienna district, Blaine County, Idaho: Idaho Bur. Mines and Geology Pamphlet 21, pp. 7, 8, 1927

38 Ross, C. P., The copper deposits near Salmon, Idaho: U.S. Geol. Survey Bull. 774, p. 14, 1925.
} 
faulting in the Challis volcanics has had little effect on the topography of the ridge tops except insofar as it has facilitated the encroachment of stream valleys on either side.

A study of the topographic map and of numerous profiles drawn from it strengthens the impression gained in the field that most of the high ridge crests are remnants of a single surface of low relief. This surface would for the most part lie between altitudes of 8,500 and 9,000 feet, with hills a few hundred feet high reaching above it. Clearly, the long sloping ridges that project laterally into the valleys have been much modified by erosion. Many of them that may have had original altitudes comparable to those of the higher ridges now lie only about 8,000 feet above sea level. Some of these are composed of soft, porous tuff and may well have weathered down to their present altitude with little change in form. Others may owe their position to comparatively recent faulting or may record pauses in the dissection of the postmature surface recorded by most of the ridges. Later studies in neighboring regions have shown that this surface is coextensive with a more completely peneplaned surface elsewhere.

In addition to the level ridge tops there are several basins at comparable altitudes which are mainly of erosional origin and may be remnants of the same old surface. One of the most striking of these basins is at the head of Yankee Fork, in the extreme southeast corner of the quadrangle. This area occupies over 8 square miles within the quadrangle. It ranges in altitude from 8,000 to 8,500 feet, and the stream has cut a gorge in it which is more than 300 feet deep at the southern boundary of the quadrangle and rapidly deepens downstream. It is an area of markedly gentle topography surrounded by mountains. The peaks that bound it on the northeast are among the highest in the quadrangle. They rise 600 to 1,500 feet above the basin but drop off sharply on the north over 3,000 feet to the valley of Warm Spring Creek and on the west 2,000 feet and more into the valley of Trapper Creek. The valleys of Trapper and Warm Spring Creeks are distinctly glaciated in their upper reaches. The evidence of glaciation at the head of Yankee Fork is not sufficiently marked to indicate that the basin is primarily a large cirque. It lacks the conspicuous cliffed rim and the abundant coarse detritus characteristic of the cirques of the region. On the other hand, the facts that some of the hillocks in the basin resemble roches moutonnées and that some of the branches of Yankee Fork on the north side of the area have cirques at their heads suggest that glaciation played some part in molding the basin into its present form. The sharp bend of Yankee Fork to the south and southwest after leaving the eastward-sloping basin is not what would be expected as a result of normal stream erosion. This bend, coupled with the lack of trenching by the river near its head and the persistence of 
poorly drained areas in the basin, suggests that the basin was in existence before Yankee Fork had extended its branches so far north and that it has only recently been incorporated into the drainage basin of that stream.

All the other basins in the Casto quadrangle, at altitudes of 8,000 feet and more, which may be genetically similar to that just described, are much smaller. As all have been glaciated, it is difficult to make a positive distinction between them and the cirques that are so common in the region. The basins that seem most likely to have had an origin similar to that of the one at the head of Yankee Fork are those at the heads of Grouse and Bernard Creeks, in the southwestern part of the quadrangle. Many others, such as those at the heads of Cache, Canyon, Fawn, and Deer Creeks, may have had such an origin, although the effects of glaciation are more marked than on Yankee Fork. Neither the large basin at the head of Yankee Fork nor the smaller ones such as that of Grouse Creek are of structural origin. The basin at the head of Yankee Fork is in part floored by soft tuff and in part by the overlying Yankee Fork rhyolite. This at first glance suggests that the basin results from recent stripping off of the rhyolite. The surface of the basin, however, is inclined eastward at an average angle of $3^{\circ}$ or less, whereas the rhyolite has an average strike of about N. $70^{\circ} \mathrm{E}$. and dips $10^{\circ}$ and more to the southeast. This discordance seems sufficient to indicate that any effect erosion of the rhyolite may have had on the formation of the basin must have been of secondary importance.

\section{LATE TERTIARY AND EARLY QUATERNARY EVENTS}

TERRACES AND RELATED FEATURES

All the larger stream valleys in the quadrangle have terraces at intervals along their slopes. Those on the Middle Fork are the best developed, but there are fine examples of terracing on Loon and Camas Creeks. The most perfectly formed sets of terraces are at the confluences of two or more large streams. Those utilized by the Boyle and Meyers Cove ranches are striking examples. Most of the terraces are carved in whole or in part out of solid rock, and many are capped by alluvium. Each terrace marks a stage in the progress of deepening the stream valley containing it.

The valleys are to some degree dependent, for their location and trend, on the character and structure of the underlying rock, especially those of the minor tributaries, many of which have followed fault zones; but the principal agent in their development has been the renewed erosive power of the streams resulting from the repeated uplifts of the region, causing the valleys to be broadened and deepened regardless of the local rock or structure. The greatest deepening, where the Middle Fork of the Salmon River leaves the north 
edge of the quadrangle at an altitude of 3,600 feet, is 4,900 feet below the average altitude of the old erosion surface on Oligocene (?) lavas.

The terraces record alternations in downward and lateral cutting power due to changes in gradient and climate and to structural disturbances that have been taking place ever since the old erosion surface on the Oligocene (?) lavas was formed. In numerous localities five or more well-defined terrace remnants, one above another, can be readily identified. They indicate at least four widespread interruptions of downcutting sufficiently long to permit notable valley broadening. Among these may be mentioned terraces at about 50, $350,900,1,050$, and 1,750 feet above Trail Creek near the Boyle ranch; at about $30,90,350,850$, and 1,500 feet above Mayfield Creek near Nelson Creek; at about 70, 300, 500, 1,700, and 2,100 feet above the Middle Fork in the general vicinity of the Cameron ranch; and similar groups elsewhere. These altitudes are estimated from aneroid observations and from the contours on the map. Many of the terraces are not adequately shown on plate 1 because of its small scale. In most localities there are smaller or less well-defined terrace remnants in addition to the larger ones such as are listed above. No attempt was made to trace out the relations between the various terrace remnants by actual surveying, but the observations made led to the conclusion that terraces of sufficient size to mark noteworthy stages in the development of the topography exist in the larger valleys at altitudes above present stream level of somewhat less than 100 feet, about 300 feet, about 500 feet, and somewhat less than 1,000 feet, and that others less extensively preserved occur at higher altitudes. The highest terraces are generally on interstream spurs with little or no gravel on them. In addition there are at several places, as at Meyers Cove and on the Middle Fork near the mouth of Camas Creek, three or more small but generally clean-cut terraces less than 75 feet above stream level. These mark minor fluctuations whose record is preserved because they took place in geologically recent time.

The higher terraces are cut in rock and rarely have more than a thin veneer of coarse gravel on them. In contrast to this the terraces at less than 100 feet above present stream level are in large part composed of gravel, sand, and silt. These are the terraces on which is most of the arable land in the quadrangle and which have yielded much of the placer gold. In most valleys there is an inner gorge 20 feet or more deep cut in rock. At the bottom of this gorge are more or less discontinuous areas of modern flood plain. Probably the alluvium of the flood plains is rarely more than a few feet thick. These flood plains contain rich soil but, being generally narrow and subjected to floods, are less suited to cultivation than 
the terraces above them. They have yielded small amounts of placer gold.

The alluvium mapped on plate 1 includes all unconsolidated detrital material except such as is clearly the product of landslides and such glacial deposits as could be differentiated from the stream deposits on the basis of form. Small areas of thin alluvium on highlevel terraces are not shown. On many streams there is considerable alluvium in the upper reaches, then for a considerable distance there is little or none, and generally there is more or less alluvium at the mouth. The lower courses of most of the streams contain more rapids and are enclosed in narrower and steeper-walled valleys than the upper reaches of the streams below the cirques at their heads. Many stream valleys become sharply constricted in the immediate vicinity of their mouths. This is well illustrated by Trail Creek (Lightning Point Creek) near the junction of Camas Creek and its South Fork, east of the quadrangle boundary. The trail follows the stream closely in its middle reaches but near its mouth is forced to climb and take a circuituous route on the face of the bluffs. Some streams, like Camas Creek, have the greatest constriction a short distance above the mouth, giving space for dumping detritus below the constriction. These features, though readily recognized in the field, are not well shown on plate 1 because of its small scale and large contour interval.

\section{GLACIATION \\ DISTRIBUTION AND EXTENT}

There is abundant evidence of the former presence of numerous glaciers, which were active after the valleys of the quadrangle had been carved nearly to their present magnitude. This evidence includes valleys with $U$-shaped cross sections, as contrasted with the $V$-shaped valleys carved wholly by stream action, and steep-walled cirques at the heads of valleys, in part floored with glacially polished rock, the hollows in which are occupied by small lakes. Although well-defined moraines are rare, poorly sorted and subangular glacial detritus is present in numerous localities. The small lateral moraines flanking Rock Creek at an altitude of about 8,000 feet are among the best examples of such features. Notable amounts of glacial detritus remain on Mayfield Creek near the mouth of Nelson Creek and at several other places, as is indicated on the map, but weathering and erosion have modified their original forms.

The glaciers were widely distributed over the quadrangle. Probably all valleys heading at altitudes in excess of 8,000 feet above sea level had glaciers at their heads. Many of the trunk glaciers flowed down the valleys to altitudes of 7,000 feet or lower, and several, such as those in the East Fork of Mayfield Creek and in Liberty Pole Creek, extended nearly as far down as the 6,000-foot contour. Nearly 
all the glaciers were small, and many never extended far beyond the cirques in which they originated. The vicinity of Sleeping Deer Mountain was one of the greatest gathering grounds for glaciers. Plate $4, B$, shows a group of cirque lakes in this vicinity. The Cache Creek Basin, north of Sleeping Deer Mountain, was formed by the coalescence of several cirques and held the largest expanse of ice in the quadrangle with the possible exception of that at the head of Yankee Fork. The ridge in the northwest corner of the quadrangle, on which are Shellrock and Two Point Peaks, was sculptured by numerous small cirques, and its upper slopes still remain almost devoid of soil or vegetation. The vicinity of Pinyon Peak was the gathering ground for several comparatively large glaciers. The terraced basin at the head of Canyon Creek, under the shadow of that massive peak, owes its picturesqueness to glacial work. This basin has not been marred by such fires as have made the Cache Creek Basin a dismal spot.

The rim of hills around the head of Yankee Fork is scalloped in several places by cirques, but these are all small. Some of the hillocks within the basin resemble roches moutonnées, but their gentle eastward slopes are essentially parallel to the dip of the strata composing them and may well be due to normal erosion and little, if at all, affected by the ice action. The undrained hollow below this rim, indicated by a depression contour on plate 1 , might possibly be interpreted as a product of glacial scour but is better explained in other ways. This depression is floored by soft and easily disintegrating tuff and rimmed on all but the west side by resistant rhyolite. It seems probable that the depression results from collapse of the rhyolite as the tuff was removed from beneath it, partly by undercutting, partly by disintegration and solution by ground water, perhaps coupled with more or less transportation in underground channels. It is believed that the area at the head of Yankee Fork owes little of its present form to glaciation. If any considerable part of it was ever covered by a glacier, the ice probably did not attain any great thickness nor persist very long. As stated elsewhere, it it probable that this area is a remnant of an erosion surface formed long before the advent of glaciation.

\section{AGE OF PRINCIPAL GLACIATION}

The character of the cirques and of the glacial detritus varies so little in different parts of the quadrangle that probably nearly all the glaciers that produced them existed at the same stage of glaciation. A few of the cirques, particularly in the southwestern part of the quadrangle, show more slumping of the walls and other modification by weathering and erosion than the others, but this difference is as readily explained by relatively low resistance of the local rocks to weathering as by an inference of greater age. As the cirques are in 
general well preserved, and the rock basins in them have not yet been filled by sediment or otherwise obliterated, it is thought that they were formed during the last or Wisconsin glacial stage of the Pleistocene.

Some doubt is cast on this conclusion by the absence of numerous well-formed moraines, such as are generally preserved in other regions where Wisconsin glaciers have been active. Their scarcity, however, seems adequately explained by the fact that in the narrow valleys of this region large moraines could not have developed and small ones would be rapidly modified or obliterated by erosion.

DEPOSITS OF GLACIAL AND AQUEOGLACIAL ORIGIN

Only material of glacial origin which has undergone little or no transportation subsequent to glaciation is mapped as till on plate 1 . The alluvium that floors many of the cirques is largely reworked glacial debris. Much of the gravel farther downstream is a combination of glacial outwash and the products of erosion of any preexisting moraines. Among the more striking examples of large detrital accumulations thus intimately related to glaciation are those on which the old towns of Ivers and Yellowjacket were built. The material is largely poorly sorted and rounded boulders and cobbles like glacial debris, but the present form of the deposits is that of stream flood plains.

The lower stream terraces are largely composed of gravel. Evidently at one period in their development many of the valleys were filled with gravel to heights 30 feet or more above their present flood plains. This filling was one of the latest events before the rejuvenation that started the down-cutting now in progress. It is probable that the filling resulted from an overloading of the streams with coarse detritus during and immediately after the Wisconsin glaciation.

\section{POSSIBLE OLDER GLACIATION}

One feature that suggests an earlier stage of glaciation is the presence of coarse detritus high on the slope on the west side of Loon Creek near the Boyle ranch. This detritus is poorly sorted and consists of subangular to partly rounded boulders, gravel, and sand. Most of the boulders are 2 to 3 feet long, but some reach 10 feet or more. They are composed mainly of granitic rocks such as crop out south and west of this locality, although the bedrock on which the detritus rests is mainly metamorphic sedimentary rock. The boulders are so thoroughly weathered that they crumble easily. The material looks much like a deposit of till that was originally perched more than 1,000 feet above Loon Creek and was later undercut by that stream until its lowest part slid down almost to present stream level.

Only the thicker portions of this mass are mapped-on plate 1 . Boulders of similar character are scattered over a considerable area on the Trail Creek slope to the southwest at an altitude of about 7,000 feet, or about 1,100 feet above Trail Creek. They are more abundant 


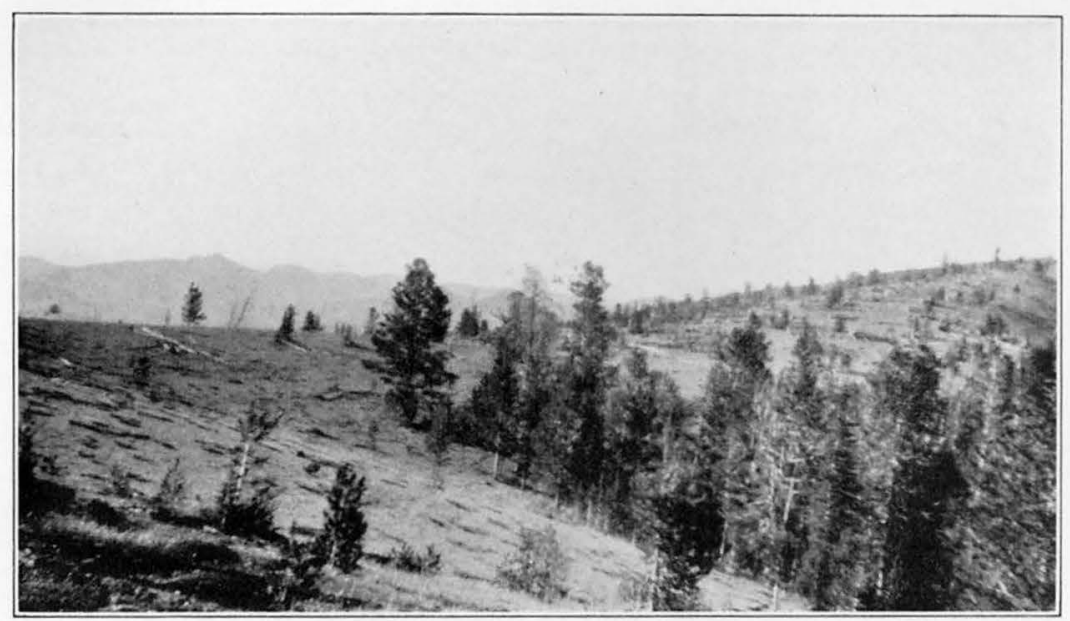

A. LEVEL-TOPPED RIDGE ON "HIGH TRAIL" NEAR HEAD OF SPIDER CREEK.

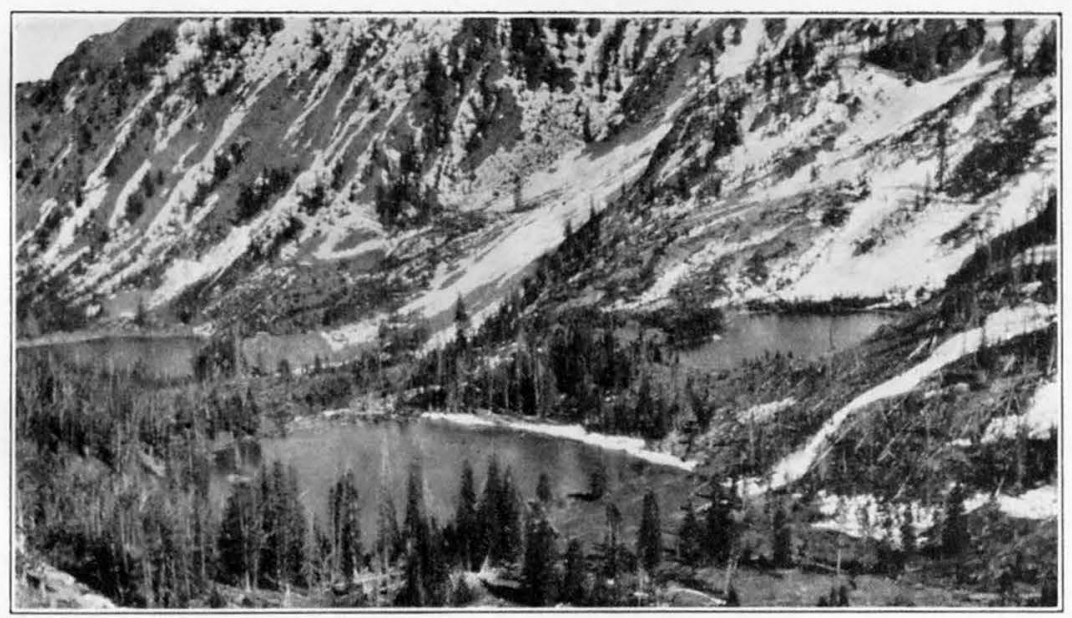

B. CIRQUE LAKE AT HEAD OF WEST FORK OF CAMAS CREEK. Pothograph by C. H. Behre, Jr. 


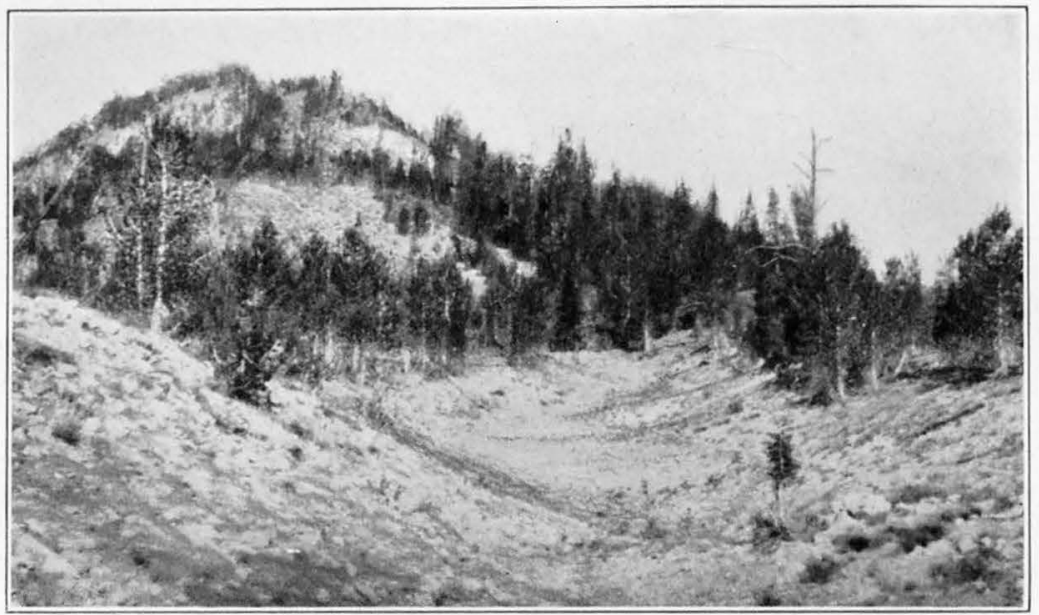

A. RIDGE-CREST DEPRESSION ON RIDGE NEAR “HIGH TRAIL," CLOSE TO HEAD OF HOT CREEK.

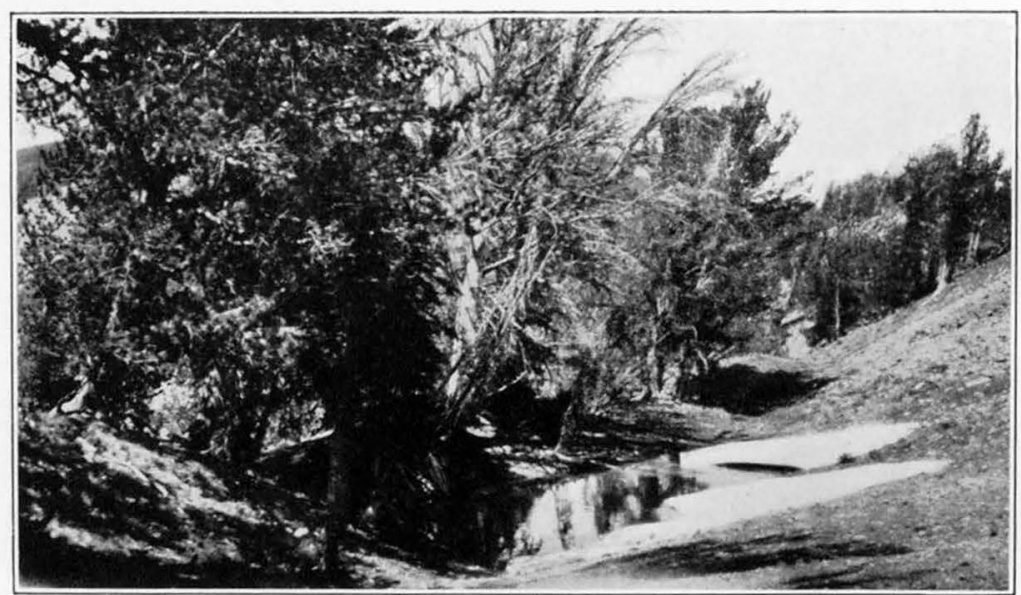

B. UNDRAINED HOLLOW AT HEAD OF ONE FORK OF GROUSE CREEK. 
in the hollows than on the spurs. There was some glaciation at the head of Deer Creek and perhaps at the heads of other gulches in this vicinity in Wisconsin time, but the quantity of till in the mass under discussion is out of proportion to the quantity that would be expected to be derived from glaciers as small as these must have been. The valleys of Loon Creek and the other large streams in this vicinity were not glaciated down so far from their heads, and the most probable explanation of this mass of weathered detritus is that it is a product of Pleistocene glaciation so much older than the Wisconsin stage that the record of it has been obliterated in most other parts of the region. ${ }^{39}$ The relation of this mass to Loon and Trail Creeks suggests that there may have been as much as 1,000 feet depth of erosion between the date of its deposition and the present time.

\section{RIDGE-CREST DEPRESSIONS}

One of the interesting details of the topography of the region is the presence of small depressions on ridge crests. A characteristic depression of this type is shown in plate $5, A$. Such depressions have been noted in the ridge between Warm Spring Creek and the South Fork of Camas Creek, in the ridge between Loon Creek and the Middle Fork, west and north of Sleeping Deer Mountain, and in numerous other localities. They occur in rocks of widely differing hardness, having been noted in most of the different kinds of rocks in the quadrangle. Many of them are almost on the precise top of the ridge and are elongate parallel to its trend. They are generally less than 100 feet long and 20 feet wide and are 10 feet in maximum depth. The lowest point on the rim is generally at one of the ends but is well above the bottom of the depression. Snow banks linger in these depressions after they have melted from other places in the vicinity. Many of the depressions are cut out of bare rock and are floored with small angular bits of this rock. No indication of shearing or of any other factor in the rock that would accelerate its removal was observed in any of these rock-walled depressions. There are somewhat similar depressions on spurs near the fault blocks of Challis volcanics on the south side of Cache Creek, whose sides are mantled with soil that conceals the structure of the bedrock. Possibly these are related in some way to the faults known to be numerous in this locality. Similar depressions occur on slopes some distance below the ridge crest, such as the one at the head of Grouse Creek shown in plate 5, $B$, and may result from landslips. Neither of these explanations appears to fit the depressions on the ridge crests with unbroken rock walls. These depressigons may be produced by breaking up of the rock by frost action, locally intensified in several possible ways, and removal of the finer particles thus formed by the wind.

s9 Ross, C. P., Early Pleistocene glaciation in Idaho: U.S. Geol. Survey Prof. Paper 158, p. 127, 1929. $50576-34-7$ 


\section{LANDSLIDES AND SLIPS}

The more prominent landslides are mapped on plate 1 , but there are many others which are too small to show on a map of this scale. The large ones mapped are in areas where faults are known and probably bear some relation to weakness produced in the rocks where the faulting occurred. Minor landslides are so common, however, that it is clear that such special conditions are not needed to produce them. Small slips constitute one of the major means by which erosion is enabled to proceed so rapidly in this region. The little rivulets that form as the rain pours down the steep slopes cut gullies in the loose soil to depths of several inches in a few minutes, removing the support from trees clinging in precarious positions and from talus slopes whose materials are close to the angle of rest. These in turn remove their support from rock masses whose connection with the main body has been previously weakened. Even where the rivulets fail to dislodge large masses they pick up surprising quantities of soil, loose pieces of vegetation, and fine rock debris.

The abrupt tearing away of rock masses in this manner tends to form cliffs or, where less complete, an oversteepened slope above and a depression or relatively flat area on top of the slumped material. (See pl. 5, B.) Continuation of the process in locations so near the ridge crests that the depressions cannot be filled may, under favorable conditions, result in forming high-level basins partly enclosed by cliffs, which give to them a superficial resemblance to glacial cirques. It is thought possible that some of the cirquelike basins in this region, especially in areas of Challis volcanics, may have been formed in this way, at least in part. The closely spaced basins on the north side of the ridge extending east from Norton Lake in T. 18 N., R. $13 \mathrm{E}$., may be examples of this process. These basins have precipitous walls over 300 feet high. They contain abundant angular talus derived from these walls but no deposits or other features clearly of glacial origin.

\section{SUMMARY}

Through Mesozoic and early Tertiary time the region was undergoing erosion. Before the advent of the Challis volcanics (Oligocene?) the erosion had proceeded far enough to produce comparatively low relief. There is no indication that the streams of that time were able to transport much gravel. There may have been hills, but it is probable that the country was far less mountainous and stood at a much lower level than it does today. Within the quadrangle this old surface was completely inundated. With the possible exception of small patches recently exhumed from beneath the lava, no remnants of this ancient surface appear in the present topography of the Castro quadrangle. This does not preclude the possibility that remnants of it may be exposed elsewhere in the surrounding region. 
The eruption of the Tertiary lava and pyroclastic materials occupied a long time, and erosion must have proceeded concomitantly with the volcanism, but the only pause in the eruptions long enough to permit the development of an erosion surface of any extent appears to have been in the interval immediately preceding the deposition of the Yankee Fork rhyolite.

During and after the volcanism there was uplift and deformation of the volcanic strata. This was followed by sufficient pause in the structural disturbances to permit erosion to proceed a long way toward the completion of an erosion cycle. The process stopped considerably short of peneplanation, but the region acquired a rolling postmature topography which, exclusive of monadnocks, had a maximum relief of 1,000 feet or less and for the most part had a relief of only a few hundred feet. Monadnocks were fairly numerous. Many of them were isolated hills a few hundred feet high, but in some places there were connected ranges of moderately steep hills some of which rose 1,500 feet above the surrounding country. There is no way to determine accurately the time of formation of this erosion surface, but the data at hand suggest that it took place after middle Miocene and before later Pliocene time. It may therefore be assumed to be of early Pliocene age. Later studies in neighboring areas have shown that an erosion surface of this age may be traced over much of central Idaho and that in most localities it more nearly approximates a peneplain than it does in the Casto quadrangle.

Renewal of uplift interrupted the peneplanation, and elevation of the region has proceeded intermittently to the present day. The uplift since the early Pliocene is estimated roughly at 3,000 feet, the difference in altitude between the old erosion surface and the lowlands east of the Salmon River Mountains; but the difference between this erosion surface and the Middle Fork of the Salmon River is 4,900 feet.

The uplift proceeded by stages. Four of these stages left fairly plain records, and there were undoubtedly several others. In none of them did the erosion cycle approach old age. The only one in which aggradation appears to have been a potent factor is that believed to be related to glaciation. The others appear to have been merely pauses in the general process of down-cutting sufficiently long to allow lateral planation to make such an impression on the topography that some portion of it has survived to the present time. The one or more glacial episodes added many details to the sculpture of the mountains and helped to produce the detrital material so essential to the rancher and the placer miner. These are the only events in the geomorphic history in which change in climate, rather than structural disturbances, are known to have played the dominant 
part. Even the climatic changes that caused the glaciation in these mountains were to some degree influenced by the uplift, although the fundamental causes of glaciation during the Pleistocene epoch were world-wide.

\section{GEOLOGIC HISTORY}

The fact that in this region it has been impossible to fix the age of several of the formations within narrow limits renders interpretation of the geologic history correspondingly indefinite. The historical review that follows is presented with due recognition of this difficulty.

\section{PRE-GAMBRIAN TIME}

Umpleby ${ }^{40}$ thought that the granite gneiss, which is extensively exposed in northwestern Lemhi County, was of Archean age, but Davidson and Gray ${ }^{41}$ found that the gneiss intruded the Belt strata near Shoup. The writer has seen some of the diagnostic exposures near Shoup under the guidance of Davidson and Gray and agrees with their conclusions. It is probable that no Archean rocks are exposed in this part of Idaho.

The Yellowjacket and Hoodoo formations, which evidently belong to the Belt series, show that the marine water which covered much of northern Idaho and western Montana in Algonkian time extended into the Casto quadrangle. Here, as elsewhere, the water of that ancient sea was generally shallow, but sandy and argillaceous sediment accumulated in it to great thicknesses, showing that the sea endured for a very long period in which subsidence prevailed.

Toward the end of the Algonkian period there were orogenic disturbances of some magnitude, whose exact character remains undetermined. The dikes of Algonkian diabase indicate a minor amount of igneous activity, presumably associated with the earth movements.

\section{PALEOZOIC TIME}

The seas that spread over most of southeastern Idaho and western Montana intermittently through the Paleozoic era appear to have reached the Casto quadrangle only in the early and late parts of that era. From the late Ordovician to at least the Permian the region was probably land-a conclusion which is in accord with present information as to the distribution of the Paleozoic seas in Idaho. ${ }^{42}$ The area over which the Idaho batholith is now exposed may have been a mountain mass essentially continuously from early Paleozoic time to the present.

10 Umpleby, J. B., Geology and ore deposits of Lemhi County, Idaho: U.S. Geol. Survey Bull. 528, pp. $41-42,1913$.

" Davidson, D. M., and Gray, A., Geology of the vicinity of Shoup, Idaho (theses prepared for doctor's degrees at University of Minnesota; unpublished).

12 Ross, C. P., Some features of the Paleozoic stratigraphy of Idaho [abstract]: Washington Acad. Sci. Jour., vol. 17, no. 5, p. 125, Mar. 4, 1927. 
The overthrusting of the Algonkian strata in the northeastern part of the quadrangle appears to have taken place prior to the deposition of the Casto volcanies, which is earlier than any similar deformation in neighboring regions, so far as known. This interpretation is based on the marked difference in the amount of deformation in the Belt and Casto rocks in the northeastern part of the quadrangle.

In Permian or possibly later time volcanism broke out on a grand scale. Thousands of feet of lava and tuff were piled up. At the beginning of the eruptions the area was probably land in process of erosion by swift streams. The seashore was probably not far distant on the east and south. Perhaps it had extended far enough westward to cover parts of the Casto quadrangle. Before this period of volcanism ended, the sea had advanced far enough to permit the deposition of a little marine limestone. Most of the strata of the Casto volcanics, however, bear no evidence of submarine origin, and it may be that in this area the volcanism was principally subaerial. That which took place at about the same time in western Idaho and eastern Oregon is believed to have been largely submarine. It is not known whether the products of this period of volcanism originally spanned the gap between south-central and western Idaho. Apparently they did not extend far to the east of the present Casto quadrangle.

\section{MESOZOIC TIME}

Unless the Casto volcanics belong in part or in whole to the Mesozoic era, there are no Mesozoic stratified rocks in or near the Casto quadrangle. It is believed that the region was dry land during the whole of the era. At some time during the Mesozoic, probably in the Jurassic period or later, enormous masses of magma were introduced into the underlying rocks and consolidated as the Idaho batholith and its satellites. A conservative estimate shows that erosion up to the present time has blocked out, in the mining sense, and partly removed more than 10,000 cubic miles of granitic rock belonging to these masses. If it were possible to explore far below the surface, it would doubtless be found that the total volume of the batholith is several times this figure. The introduction of such a mass must inevitably have occasioned great disturbances in the rocks it entered and undoubtedly caused uplift on a grand scale. As this uplift progressed, the agencies of erosion were accelerated. The combined effect of broad-scale uplift and sculpture by active streams produced mountains, perhaps even grander than those of the present day.

As the intrusion spent its force, the earth movements associated with it died down. Erosion then prevailed, and the mountains again began to be worn away. The available evidence is insufficient to determine the details of events in late Mesozoic time. It may be 
that movements related to the intrusion of the Idaho batholith persisted to the end of the era. Possibly some of the magma did not find its way into its present position until that time, although it is probable that the main mass came to rest in Jurassic or at most early Cretaceous time. In the Casto quadrangle the record of late Mesozoic time is obscured by the superposed record of complicated Cenozoic events. Whatever series of events led up to it, the land appears to have been reduced to low relief near the end of the era.

\section{CENOZOIC TIME}

The gentle topography evidently produced near the end of the Cretaceous period was to some extent dissected early in Tertiary time. The rejuvenation thus indicated was initiated as a result of the great structural disturbance known as the Laramide revolution, which took place at the end of the Mesozoic or the beginning of the Cenozoic era. The effects of this revolution were widespread over the Rocky Mountain region. The diastrophism was much less intense in the Casto quadrangle, however, than it was farther east. Apparently here the rejuvenated erosion did no more than to produce local irregularities in the gentle topography attained toward the end of the Cretaceous.

Whatever the exact date of these poorly recorded events, they were followed by great volcanic activity. Much more than 1,000 feet of lava and tuff of silicic and intermediate composition were poured out. After a slight pause, these eruptions were followed by flows of rhyolite, which appear to have closed effusive activity in the quadrangle, although it persisted intermittently to a much later date in regions to the east and south.

During or shortly after the volcanism granitic magma again invaded the earth's crust in this region, although on a far smaller scale than formerly. The largest body of granitic rock of this age yet recognized in south-central Idaho is exposed in the Casto quadrangle and extends northward beyond its limits. In view of the laccolithic form of the mass, it seems likely that its total volume is little if any in excess of 450 cubic miles. Even with due allowance for the unmapped masses elsewhere, the total volume of granitic rock of this age is probably less than a tenth of that of the exposed portion of the Idaho batholith. Even this comparatively minor intrusion had associated with it uplift of the order of a few thousand feet. In and near the Casto quadrangle this uplift formed a broad arch, but under existing conditions of load and stress the arch was incompetent. It broke in numerous places, probably before some of its segments had been raised far above the positions they had prior to the uplift.

Erosion was active throughout Tertiary time, though hampered by the volcanism. The uplift added to its effectiveness, and after 
the main force of the arching had spent itself erosion gained the ascendancy. In the later part of the Cenozoic era an advanced stage of peneplanation was attained. This apparently marks the longest pause in diastrophic activity during Cenozoic time.

Minor structural disturbances, expressed mainly by movements along fault planes, were renewed after the peneplanation. They have continued intermittently up to the present day and have served to interrupt and complicate the erosional history. Their resultant effect has been repeated uplift, probably of diminishing intensity. This has served to keep erosion active. Consequently there has been general degradation from the late Pliocene to and including the present time, except for the interruptions resulting from glaciation, which freed so much material that the streams could not carry all of it away. Therefore, probably two or more times during the Pleistocene epoch, alluvium accumulated in the stream valleys. The alluvial deposits may in places have been scores of feet, perhaps even a few hundred feet thick, but such thicknesses were rare. These aggradational events were minor episodes in a history of erosional sculpture in which the mountains were carved out of the Pliocene (?) peneplain and are now in process of being worn away.

\section{MINERAL DEPOSITS}

Deposits of gold, silver, copper, lead, other metals, and opals occur in the Casto quadrangle, and some of those containing precious metals have been, worked since about 1860 . The total production from lode mines probably does not much exceed $\$ 1,000,000$, and that from placers may be little if any greater. This small production has resulted in part from the inaccessibility of the area, but all the mines are small, in comparison with those in more productive districts, and have little ore in sight; moreover, the geologic conditions imply that few of the deposits are likely to contain very large bodies of ore of a grade that could be profitably mined now or in the near future. Small deposits, obviously, could be more profitably worked if they were less remote from market. The idleness of the mines does not imply exhaustion, and there are deposits that have had no development.

\section{LOCATION}

There are three small mining districts in the quadrangle. These are the Yellowjacket district, in the extreme northeast corner; the Loon Creek district, on Loon, Canyon, and Mayfield Creeks, in the southwestern part; and the Parker Mountain district, on upper Warm Spring Creek, in the southeastern part. The Yellowjacket district is the best known. It has a long history of intermittent production, mainly of low-grade gold ore. It also contains deposits of copper and lead ores, and all its deposits contain some silver. The Loon Creek 
district contains most of the formerly productive placers in the quadrangle, the Lost Packer lode mine, which formerly produced gold and copper ore of good grade, and several prospects on gold, silver, lead, and copper ore. Contact-metamorphic limestone here has been quarried as smelter flux. This rock contains small amounts of löllingite, but apparently not enough to make it an ore of arsenic. The Parker Mountain district, the only one in Tertiary rocks, has produced a small amount of ore containing silver and gold.

In addition to these three districts there are several mineralized localities in which prospects are limited to shallow pits and cuts. These include the prospect containing stibnite in a barite gangue near Meyers Cove; several prospects containing copper and lead sulphides near the heads of Woodtick and Liberty Pole Creeks; a few prospects in the southwestern part of the quadrangle which are on the eastern border of the Sheep Mountain district; and the Valentine and other prospects located by L. Falconberry near his ranch and on Cabin Creek. At several places in and near Oligocene (?) igneous rocks some evidence of mineralization was noted during the present study, but these places are not known to have any prospect pits, although some of them have been visited by prospectors. The principal ones are near the mouth of Hot Creek, on Horse Creek, and on a tributary of Marble Creek a short distance above and east of the Mitchell ranch. If there are any valuable metals in these localities they are gold and silver, and the proportion of either is probably small. A little placer mining has been done along the Middle Fork and probably in some of the other valleys, in addition to that in the mining districts previously mentioned. Opals were noted during the present investigation on a northern tributary of the South Fork of Camas Creek nearly 3 miles above its mouth. They probably occur elsewhere in the quadrangle, but no attempt appears to have been made to mine them.

\section{KINDS OF LODES}

Broadly considered, there are in the region five kinds of deposits containing metallic minerals-(1) shear zones containing copper and lead sulphides with more or less gold and silver in a gangue generally containing siderite; (2) veins and breccia zones characterized by the presence of fine-grained ribbon-banded quartz, principally valuable for their gold and silver content; (3) disseminated pyrite in somewhat altered hornblende granite; (4) gash veins of glassy quartz with pyrrhotite; (5) contact-metamorphic limestone containing löllingite and small amounts of precious metals. Only the first two have been worked for metals on a commercial scale. The first type includes all the deposits in the Yellowjacket district and the principal deposits in the Loon Creek district. It probably also includes those deposits that 
have been prospected in the general vicinity of Sleeping Deer Mountain, the Valentine prospect, and perhaps those within the quadrangle near Sheep Mountain, which are so slightly developed and of such little value that they will not be further considered. Farther west the Sheep Mountain and Seafoam districts ${ }^{43}$ contain some promising deposits of this type. The second type listed above includes the deposits of the Parker Mountain district, the barite-stibnite deposit near Meyers Cove, and undeveloped deposits on lower Warm Spring Creek and near Marble Creek. Description of the third type has been more conveniently included with that of the Micoene granite on pages 57-58. The fourth type has been noted only on Deer Creek in the Loon Creek district and is briefly considered in the description of that district but is not known to have any commercial value. The fifth type has been developed only as flux for the smelter at Ivers. The flux quarries are briefly described in the account of the Loon Creek district, and the contact metamorphism in them is discussed in some detail by W. H. Newhouse on pages $68-72$.

\section{SHEAR ZONES WITH COPPER-LEAD-SIDERITE ORE (MESOZOIC)}

\section{CHARACTERISTICS}

The deposits of the first type in the Casto quadrangle are essentially similar to most of those in the larger mines of south-central Idaho. The lodes consist of shear zones containing roughly lenticular ore shoots between scantily mineralized or barren stretches. The gangue comprises varying amounts of quartz, siderite, and altered, sheared wall rock. Siderite is not present everywhere, but in each of the deposits that have been developed to any considerable extent it is abundant in places. In parts of some lodes the place of siderite is taken by ferruginous or manganiferous calcite. This appears to be true of some of the deposits in the Yellowjacket district, notably in the Yellowjacket mine, but it is not characteristic for most deposits of the type in the general region. The principal metallic minerals are chalcopyrite, galena, pyrite, and tetrahedrite. The proportions vary, but the last two are generally very subordinate in amount. Where chalcopyrite is abundant galena is rare, and vice versa. In the upper levels of the Yellowjacket and in some of the nearby mines hypogene sulphides are not abundant and the ore is mainly valuable for its gold and silver content. In these deposits the relatively small content of base metals is a detriment rather than an advantage. Such essentially precious-metal lodes are rare in the region as a whole and are numerically in the minority even in the Yellowjacket district.

\footnotetext{
is Ross, C. P., Geology and ore deposits of the Seafoam, Alder Creek, Little Smoky, and Willow Creek mining districts, Custer and Camas Counties, Idaho: Idaho Bur. Mines and Geology Pamphlet 33, pp. $1-6,1930$.
} 
In the lodes of this type ore deposition took place mainly by replacement and only secondarily by filling of open fissures. As the country rock in and outside of the lenses of ore appears to be essentially the same in many localities it is probable that the controlling factors in forming the ore shoots were structural. Presumably deposition was greatest where the rock was much sheared but was, at the time of mineralization, not as tightly compressed as the other portions of the shear zone. In most places the different ore shoots in a given lode lie approximately in the same plane, except insofar as they are displaced by postmineral faulting. Where the shear zones are wide or where there are several shear zones close together, this is locally not the case. In such places successive shoots have a steplike arrangement. It may even happen that at a given place in the lode there are two or more parallel shoots at the same altitude, separated by essentially barren rock. Locally, instead of an isolated and essentially continuous shear zone, there is a system of shear zones, analogous in origin and pattern to a joint system. In such a system the individual segments are essentially parallel to one another but are offset both along the strike and along the dip, simulating the effect produced by the breaking up of a single shear zone by a set of parallel faults. If, as is generally true of joints, there is a complementary set of shear planes striking at high angles to the major shearing, the resemblance to a faulted lode is close. There is some suggestion of regular steplike arrangement in the ore lenses of the Yellowjacket mine, and present exposures afford no proof of any transverse faulting that might account for them as offsets. Parallel segments of the lode in the Lost Packer mine, in the Loon Creek district, are arranged in a regular manner. Postmineral porphyry occupies the gaps between the segments. The theory advanced by those familiar with the mine is that the lode has been broken by faults associated with the intrusion of the porphyry; but in workings accessible to the writer no such faults could be found, and it is more probable that the positions of the shoots are original and the presence of the porphyry incidental. The steplike arrangement of ore shoots is illustrated on a small scale in the Continental prospect. There numerous lenses of vein matter a few inches thick are exposed. In several places lenses terminate and similar lenses start short distances to one side or the other. In most such places it is clear that the lenses are separate entities and not faulted segments of a single lens.

Experience in the Wood River region ${ }^{44}$ and elsewhere in southcentral Idaho suggests that this steplike arrangement should be constantly borne in mind. It is certainly true that ore shoots in

4t Umpleby, J. B., Westgate, L. G., and Ross, C. P., Geology and ore deposits of the Wood River region, Idaho: U.S. Geol. Survey Bull. 814, pp. 96-105, 1930. 
several of the mines of that region terminate both along the strike and along the dip without being faulted, although faulting is frequently offered as an explanation for their terminations.

Where a lode consists of separate lenses instead of faulted segments the uncertainties of development are, in a measure, increased, as it is impossible to predict how far away the next mineralized zone may be. In numerous lodes in the Wood River region only one valuable ore shoot has been found, and exploration at depth has been unrewarded. On the other hand, there are some favorable features of this mode of occurrence. If two or more ore shoots have been found, the system of shearing can be determined from their mutual relations. Additional shoots with similar relations may be expected, both laterally and in depth. Under the conception here outlined the shear-zone systems, like joint systems, may have resulted from the application of forces connected with major deformational processes of widespread influence. Hence they may be expected to show regularity and similarity under similar conditions, so that deductions based on studies of developed lodes may, with proper limitations, be applied to similar but less developed deposits in the same region. Crosscuts from known ore bodies have proved profitable in numerous mines in south-central Idaho, such as the Independence mine, near Ketchum, and exploration by crosscutting should be considered in similar mines, both in the Casto quadrangle and elsewhere in this part of Idaho.

\section{GENETIC RELATIONS}

The ore deposits with sideritic gangue in shear zones throughout south-central Idaho have generally been considered to be genetically related to the Idaho batholith or to essentially contemporaneous offshoots of that batholith. This theory is in accord with the data regarding such ore deposits in the Casto quadrangle, though its acceptance is based more on available data for the region as a whole than on the evidence afforded within the quadrangle itself. As ore deposition is regarded as a late phase of plutonic activity, it is not surprising to find that ore shoots at the Lost Packer mine are later than aplite dikes related to the Idaho batholith. They are earlier than the Tertiary dikes.

\section{MINERAL DEPOSITS WITH FINE RIBBON-BANDED QUARTZ (MIOCENE)}

\section{CHARACTERISTICS}

The mineral deposits characterized by fine-grained ribbon-banded quartz are most likely to be valuable for their precious-metal content. Most of them in this region rarely contain enough metallic minerals to be visible on casual inspection. Part of the precious-metal content 
is in the free state, and part is present as selenide. ${ }^{45}$ No selenide ore rich enough to permit isolation of the mineral for complete analysis has been obtained, but tests show that it consists essentially of silver, sulphur, and selenium and hence corresponds to aguilarite $\left(\mathrm{Ag}_{2} \mathrm{~S} . \mathrm{Ag}_{2} \mathrm{Se}\right)^{46}$ rather than naumannite $\left(\left(\mathrm{Ag}_{2}, \mathrm{~Pb}\right) \mathrm{Se}\right) .^{46}$ However, the formulas given are empirical, and it is probable that an isomorphous series of sulphides and selenides exists. In the Parker Mountain district a little adularia is reported to occur in the quartz. Feldspar in the lava close to the lodes is kaolinized, and there are seams of hydromica which may represent a late stage of hypogene mineralization. Some of the deposits of this type contain fluorite. That near Meyers Cove has abundant barite and also contains stibnite, which has not been identified in other deposits of this general type. None of the deposits with abundant fluorite in the quadrangle are known to contain precious metals.

\section{STRUCTURAL FEATURES}

These deposits, like those previously described, are on shear zones without clean-cut walls. They have been formed in part by replacement and in part by fissure filling and are accompanied by much more brecciation than those of the first type. This brecciation, characterized by angular fragments, was recurrent, as is well illustrated at the barite-stibnite prospect and less strikingly elsewhere. There are numerous small veins filling cracks, many of which have no systematic arrangement. This evidence as a whole implies formation under much less pressure than was operative during the sideritic mineralization.

So far as development has progressed, the lodes of this type in the quadrangle appear to be rather small, of low grade, and discontinuous. Such high-grade ore as has been found is exceptional and invariably small in amount. Mineralization of this type is, however, widespread in several places, notably the Parker Mountain district, and it may be that careful prospecting will disclose sufficiently large blocks of mineralized ground which, even if of average low grade, will repay development after transporattion conditions are improved.

\section{GENETIC RELATIONS}

All the mineral deposits of this type are in the Challis volcanics or in Miocene intrusive rocks, except perhaps some of those on Warm Spring Creek. As suggested in a previous report, ${ }^{47}$ they are probably closely related to the Miocene granitic rocks extensively exposed in this quadrangle.

\footnotetext{
is Ross, C. P., Ore deposition in Tertiary lava in the Salmon River Mountains, Idaho: Idaho Bur. Mines and Geology Pamphlet 25, pp. 13-14, 1927; also later studies of high-grade specimens from Parker Mountain in the U.S. Geol. Survey laboratories.

40 Dana, E. S., System of mineralogy, pp. 52, 1025, 1909.

7 Ross, C. P., op. cit. (Pamphlet 25), p. 10.
} 


\section{SUPERGENE PROCESSES}

In most of the mineral deposits of the quadrangle there is little evidence of oxidation below a depth of 50 feet. It is common to find pyrite and other sulphides almost unoxidized at the surface. Evidently erosion has been so active that it has nearly kept pace with oxidation in most localities. The Yellowjacket mine, where the only considerable body of sulphide known is some 300 feet below the surface, may be an exception to this rule.

Below the shallow zone of oxidation in such copper deposits as the Lost Packer and the Copper Glance there has been a little enrichment by deposition from supergene solutions. Except in some of the Copper Glance ore, this process has not gone far enough to be of any commercial importance, and even at the Copper Glance the quantity of enriched ore is probably not large.

In some of the precious-metal deposits supergene processes may have been of more economic importance. Throughout the open cuts of the Yellowjacket mine oxidation has largely removed the sulphides, and the average content of the less soluble precious metals has accordingly been increased.

The pockets of high-grade gold ore that have proved so valuable to prospectors in the Parker Mountain district have been thought by some to be of supergene origin and consequently to be expected only in the vicinity of the surface. Most of the ore from such bodies seen by the writer shows little evidence of supergene processes. Much of the precious-metal content of such ore is clearly in the hypogene selenide and sulphide minerals. Where free gold is visible it is so intimately associated with these minerals as to indicate a similar origin.

\section{PLACER DEPOSITS}

Extensive placer mining has been carried on in the past on Yellowjacket Creek just below the old town of Yellowjacket and on Loon Creek in the vicinity of the old town of Casto, but the only considerable production appears to have come from the Loon Creek district. On both Loon and Yellowjacket Creeks there is more alluvial material present than can be accounted for simply by the action of present streams, and most of it, as stated on page 90 , is closely related to glaciation. A little placer mining was done in the summer of 1926 on the south side of the Middle Fork near Red Bluff Creek, and similar minor operations have probably been undertaken elsewhere at various times. According to local report much of the alluvium in the region, if carefully panned, will yield small quantities of gold derived from small scattered mineral deposits; but, with such exceptions as Yellowjacket and Loon Creeks, both the lodes and the placers derived from them are too small or of too low grade to be profitably mined. 
The gravel near the old town of Yellowjacket was productive for a time, but operations appear to have been disappointing. This gravel has been described on page 90 as glacial material only moderately sorted by water. Such material rarely contains valuable placer deposits. The part of any given lode eroded during a glacial episode is less than that eroded during the accumulation of comparable amounts of gravel by ordinary stream erosion. Glacial denudation is mainly confined to the narrow valleys occupied by the glaciers, whereas ordinary streams receive more or less debris from the whole area drained by them; furthermore, transportation by glaciers does not concentrate gold in the debris nearly so effectively as transportation by streams. Most of the placer gold near Yellowjacket was evidently derived from nearby lodes and concentrated partly by the reworking of glacial debris and partly by postglacial erosion of the lodes. The abundance of only slightly reworked glacial debris, the short distance from the lodes, and the comparatively short time that concentration can have been in progress all militated against the formation of very valuable placer deposits.

The more productive placer deposits of the Loon Creek district have a somewhat different history. The gravel is comparatively well sorted and well bedded. It has obviously been carried a considerable distance and deposited in its present position by stream action. As stated elsewhere, much of it was evidently deposited in an interglacial interval prior to the last recorded glaciation, though it was probably derived in large part from glacial deposits. Some of it, however, including much of that which proved productive in the past, is in terraces but little above the present stream and may have been laid down subsequent to the last glaciation. In either case the gravel was carried farther and sorted better, for the most part, than that near Yellowjacket, and there was a much better concentration of the gold. The gold is reported to have been on the average exceptionally coarse, which implies that it was not transported very far from its source by streams. This evidence is in accord with the origin of the gravel indicated above. Some of the gold probably came from the Lost Packer and neighboring lodes, 5 to 10 miles away, and none apparently came from a more distant source than the head of Mayfield Creek, nearly 20 miles away.

\section{OPALS}

No opals appear to have been mined anywhere in the Casto quadrangle, but it is probable that specimens of gem quality can be found there. Opals were noted ${ }^{48}$ in the course of the geologic mapping on a northern tributary of the South Fork of Camas Creek nearly 3 miles above the confluence with Camas Creek. The opals occur near the head of the east branch of the tributary and nearly three-quarters of a mile from the South Fork. They are in fractures and vesicles in 
dark-purple and green glassy rhyolite and black obsidian, below a prominent bed of cream-colored tuff. Most of the opaline material here is not of gem quality, but some of it has fire, and the locality is worth prospecting by anyone interested in opal mining. This deposit, however, may present the same difficulty as that at Panther Creek, which is one of several opal deposits known to occur east of the Casto quadrangle. An attempt to mine opals was made at Panther Creek ${ }^{48}$ early in the present century but is said to have been abandoned, mainly because the opals were so brittle that they could not be removed from the hard enclosing rock without excessive fracturing.

\section{HOT SPRINGS}

Distribution.-Hot springs are shown in 10 localities on plate 1 . In nearly all of these there are several spring openings, and in several, as on Loon Creek near the mouth of Warm Spring Creek, there are a considerable number of springs. In addition to the localities mapped there are several other places, such as the mouth of Little Woodtick Creek, where there are hot or warm springs. Also, there are some places, generally high above present streams, where there is evidence of the former presence of hot springs.

Character.-Commonly the springs issue from cracks in rocky bluffs a few feet above the present streams. In a few places, notably on Loon Creek above the mouth of Warm Spring Creek, the spring water emerges through alluvium. At most of the springs the rock over which the water flows is whitened by a film of tufa, and at all the springs green and brown algae are present. Chemical and other data on several representative springs are summarized below. It will be seen that the springs contain only moderate amounts of dissolved mineral matter, in which sodium carbonate predominates.

Analyses of hot-spring waters in Casto quadrangle

[Parts per million. Analyst, C. S. Howard, U.S. Geol. Survey. Samples collected July 2-4, 1925.]

\begin{tabular}{|c|c|c|c|c|c|c|c|}
\hline & 3483 & 3482 & 3479 & & 3483 & 3482 & 3479 \\
\hline $\begin{array}{l}\mathrm{SiO}_{2} \\
\mathrm{Fe} \\
\mathrm{Ca} \\
\mathrm{Mg}_{-} \\
\mathrm{Na}+\mathrm{K} \\
\mathrm{CO}_{3}\end{array}$ & $\begin{array}{l}60 \\
.06 \\
4.0 \\
75^{.6} \\
23\end{array}$ & $\begin{array}{l}55 \\
4.10 \\
4.1 \\
74^{8}\end{array}$ & $\begin{array}{r}52 \\
4.6 \\
44^{.6} \\
29\end{array}$ & $\begin{array}{l}\mathrm{HCO} \\
\mathrm{SO}_{4} \\
\mathrm{Cl}_{3} \\
\mathrm{NO} \mathrm{O}_{3} \ldots \\
\text { Hardness (ealculated) } \\
\text { Total dissolved solids....... }\end{array}$ & $\begin{array}{r}55 \\
49 \\
14 \\
\text { Trace } \\
12 \\
278\end{array}$ & $\begin{array}{r}59 \\
53 \\
14 \\
\text { Trace } \\
14 \\
280\end{array}$ & $\begin{array}{r}30 \\
32 \\
11 \\
\text { Trace } \\
229\end{array}$ \\
\hline
\end{tabular}

Sample 3483 is from a spring on the east side of Loon Creek a short distance above the mouth of Warm Spring Creek, which on August 3, 1925, had a temperature of $120.8^{\circ} \mathrm{F}$. Other nearby springs had temperatures of $135.7^{\circ}$ and 115.1 ${ }^{\circ}$. Although the larger springs, some of which have been improved with small pools to facilitate use for washing, occur at this point, others appear at intervals to a point a short distance above Warm Spring Creek.

Sample 3482 is from a spring on Hot Creek close to its mouth, which on August 20,1925, had a temperature of $134^{\circ} \mathrm{F}$. Springs issue along this creek for

48 Ross, C. P., Ore deposits in Tertiary lava in the Salmon River Mountains, Idaho: Idaho Bur. Mines and Geology Pamphlet 25, p. 20, 1927. 
a distance of fully a mile upstream, and two of these had temperatures of $147^{\circ}$ and 140.5 There are a few springs on Warm Spring Creek just above Hot Creek; one of these which had a wooden trough had a temperature of $111.9^{\circ}$, and the one a little farther upstream, which had been pooled, measured $114.0^{\circ}$ on August 21, 1925.

Sample 3479 came from one of the hot springs that issue at intervals along Warm Spring Creek from a point a short distance above the old ranger cabin to the mouth of Parker Creek. The temperatures of two of the springs near Parker Creek on August 22, 1925 , were $122.5^{\circ}$ and $120.6^{\circ} \mathrm{F}$. Sample 3479 came from one of these.

Origin.-Some of the hot springs are grouped along lines of known faulting, as can be seen from plate 1. The others are probably also on faults of small displacement. All the living springs are close to present stream channels - that is, they emerge at or slightly above ground-water level. This indicates that they are probably not under pressure sufficient to force them far above the existing water table for the region. The fact that many emerge a few feet above the streams indicates that they may be under some small artesian pressure. The water is somewhat more mineralized than that of the streams and cold springs of the region, but the character and amount of the dissolved solids are such as might well be produced by hot water circulating through the rocks of the region, none of the components being disproportionately high. The highest observed temperature, $147^{\circ} \mathrm{F}$., corresponds to a source about 6,400 feet below the surface, at the normal temperature gradient of $1^{\circ} \mathrm{F}$. to 60 feet of depth and the mean annual temperature of about $40^{\circ} \mathrm{F}$. Most of the springs have temperatures corresponding to depths of somewhat more than 4,000 feet. If the products of the Miocene intrusion have not entirely cooled, the temperature gradient for this region may be somewhat high, and therefore the probable depth to the source of the spring water would be somewhat less. The faults, however, are relatively so recent and have displacements so large that ascent of water along them from depths as great as 6,400 feet is by no means impossible.

It is believed that the hot-spring water rose to the surface along faults from depths greater than those attained by the ground water that forms the cold springs. It may, however, not differ materially in other respects from the ordinary ground water. The observed characteristics, including the temperature, might well be acquired by ground water that originated as rain, was carried along joints and faults to considerable depth, and then rose along faults or similar channels.

Use.-At present the springs are used only for laundry and bathing by those living in or traveling through the quadrangle. At the spring near the Ramey ranch there is a bath house and timber-sided pool, now (1930) in disrepair, and at several springs small basins have been dug out. The springs are similar in size and character of water to those utilized at resorts at Beardsley Springs, Robinson Bar, and numerous other places in this part of Idaho. 

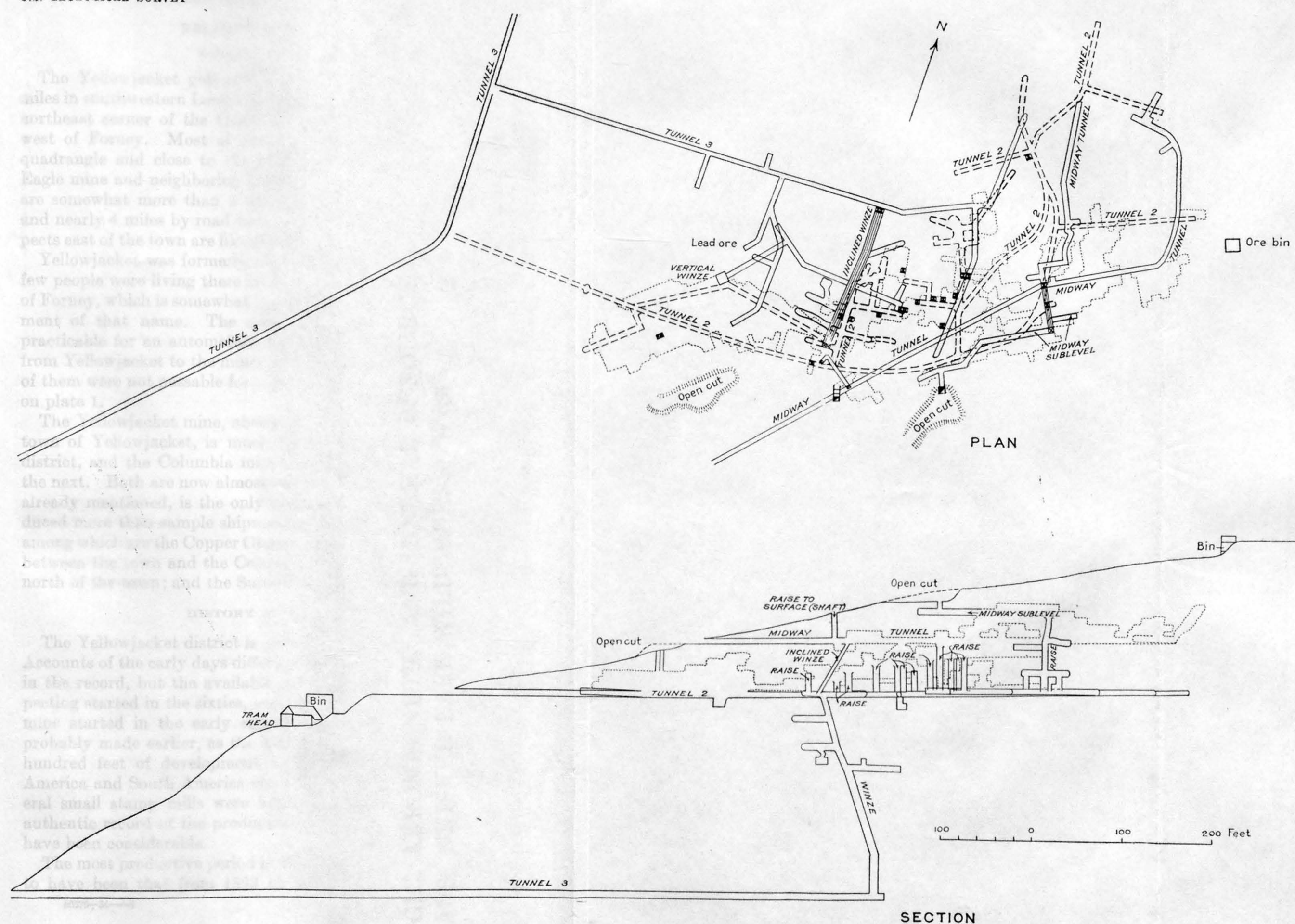

$\operatorname{Bin}$.

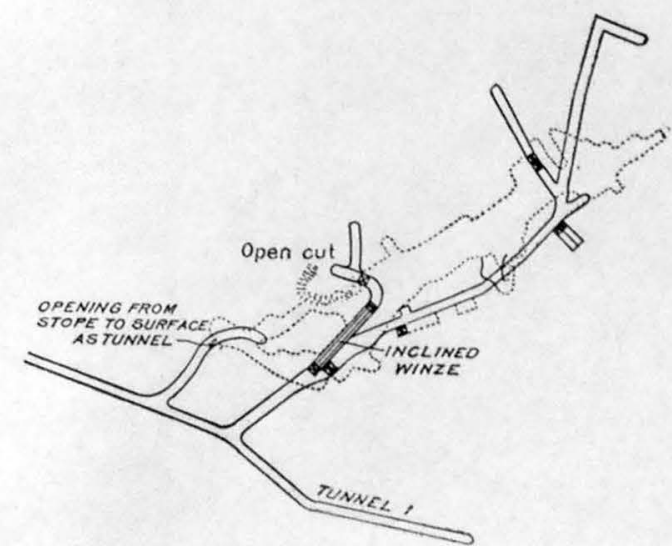

\section{EXPLANATION}

stope boundary

shart

Raise

winze

Open cut _.....-open cut

: 


\section{LOCAL DESCRIPTIONS}

\section{YELLOWJACKET DISTRICT}

LOCATION AND EXTENT

The Yellowjacket gold-mining district occupies about 10 square miles in southwestern Lemhi County. Yellowjacket is in the extreme northeast corner of the Casto quadrangle, about 12 miles by road west of Forney. Most of the mines of the district lie within the quadrangle and close to the town of Yellowjacket, but the Black Eagle mine and neighboring prospects on a branch of Hoodoo Creek are somewhat more than a mile north of the quadrangle boundary and nearly 4 miles by road from Yellowjacket, and some of the prospects east of the town are likewise outside the limits of the quadrangle.

Yellowjacket was formerly a town of considerable size, but only a few people were living there in 1930. The nearest post office is that of Forney, which is somewhat more than a mile north of the old settlement of that name. The road from Forney to Yellowjacket is practicable for an automobile, but the roads that formerly radiated from Yellowjacket to the mines of the district are in disrepair. Most of them were not passable for vehicles in 1930 and are shown as trails on plate 1.

The Yellowjacket mine, about three-fourths of a mile north of the town of Yellowjacket, is much the largest and best known in the district, and the Columbia mine, about a mile west of the town, is the next. Both are now almost completely caved. The Black Eagle, already mentioned, is the only other lode mine known to have produced more than sample shipments. There are numerous prospects, among which are the Copper Glance, east of the town; the Continental, between the town and the Columbia mine; the Red Jacket, 11/2 miles north of the town; and the Sunset, near Hoodoo Creek.

\section{HISTORY AND PRODUCTION}

The Yellowjacket district is one of the oldest in this part of Idaho. Accounts of the early days differ in various details, and there are gaps in the record, but the available data are summarized below. Prospecting started in the sixties, and extensive work at the Yellowjacket mine started in the early eighties, although some production was probably made earlier, as the Mint report for 1884 notes that many hundred feet of development work had been done on the North America and South America claims of the Yellowjacket mine. Several small stamp mills were built in the early days. There is no authentic record of the production prior to 1893 , but the total may have been considerable.

The most productive period in the history of the district is reported to have been that from 1893 to 1897 . The table below, which is 50576-34-8 
possibly incomplete, has been abstracted from old books in the Yellowjacket mine office. To this should be added the relatively small production of the Columbia mine, located in 1892, and possibly also a little from the Red Jacket, Black Eagle, Sunset, Continental, and other prospects, all of which were worked in the nineties, though none of them produced much bullion.

Bullion produced at the Yellowjacket mine, 1893-97

\begin{tabular}{|c|c|c|}
\hline Dates a & $\begin{array}{c}\text { Value of bar } \\
\text { bullion }\end{array}$ & Operating company \\
\hline \multirow[t]{2}{*}{$\begin{array}{l}\text { Nov. 2-Dec. 10, 1893 } \\
\text { Feb. 3-June 26, } 1894 \\
\text { Mar. 1-Dec. 29, } 1895 \\
\text { Jan. 6-Dec. 15, } 1896 \\
\text { June 3-June 11, } 1897\end{array}$} & $\begin{array}{r}\$ 4,060.03 \\
12,086.20 \\
60,991.11 \\
42,050.76 \\
2,573.46 \\
\end{array}$ & \multirow[t]{2}{*}{$\begin{array}{l}\text { Yellowjacket Gold Mining Co. } \\
\text { Idaho Yellowjacket Gold Mining Co. }\end{array}$} \\
\hline & $121,761.56$ & \\
\hline
\end{tabular}

a Earliest and latest dates in each year for which shipments of bullion are recorded.

The mills now existing were built during this period of maximum production. The present Yellowjacket mill was built in $1894,{ }^{49}$ replacing a 10-stamp mill which had been burned. It originally contained 30 stamps, but its capacity was gradually increased so that it now contains 12 batteries of 5 stamps each and 2 additional stamps for sampling. Power was obtained from Pelton water wheels. The cost of delivering ore to the mill was much reduced by substituting an aerial tramway, built in 1892, for wagon haulage. The ore from the Columbia mine was originally treated in the Yellowjacket mill, but in the late nineties the Columbia mill was built nearby. The ore was hauled in wagons a distance of more than a mile from the mine to the mill in the town of Yellowjacket.

From 1901 to 1910 little production appears to have been obtained from lode mines in the district. The Columbia mine was shut down about 1903. At this time an attempt was made to mine the gravel along Yellowjacket Creek immediately below the town by hydraulic methods. Evidence of considerable work can still be seen here, but the results do not appear to have been encouraging. The annual volumes of Mineral Resources record production from placers at Yellowjacket in 1906, 1907, and 1914. A little placer gold was produced in the district in 1924, but the hydraulic operations have long been abandoned.

The 5-stamp mill at the Black Eagle mine was built in 1908, according to Mineral Resources. Tunnels were driven the same year, but no production is recorded. The Yellowjacket mine was acquired by the Mandarin Mines Corporation about 1910, and a small annual production was made from 1911 to 1914 . The cyanide process was tried at this time. 
In recent years the mines have been idle much of the time. There was one shipment of high-grade gold ore from the Black Eagle in 1922, and a small lot of copper-gold ore was shipped from the Columbia in 1923. From March 1923 to January 15, 1924, the New YorkIdaho Exploration Co. undertook extensive surface improvement intended to make the Yellowjacket mine ready for reopening, but it did little underground and suspended operations before any ore was encountered. Small amounts of development work are annually accomplished at the Yellowjacket and at the Continental, Copper Glance, and other prospects.

The above summary includes all definite data available as to production, but doubtless considerable bullion was produced of which no record has been found. Umpleby ${ }^{50}$ estimated that the Yellowjacket mine had produced $\$ 450,000$ in gold, largely from ore averaging about $\$ 8$ a ton, an estimate which appears to be entirely possible, although not substantiated by available records.

\section{YELLOWJACKET MINE}

The Yellowjacket mine, much the most productive in the district, is near the top of the ridge north of the town of Yellowjacket and is connected with it by a winding road about three-fourths of a mile long. The mine was formerly connected with the mill at the base of the ridge by an aerial tramway. The property comprises 39 lode claims, 7 placer claims, and several mill sites. The development consists in a large irregular group of open cuts enlarged by stopes from below and extensive underground workings on several levels, now almost completely caved. The open cuts and caved stopes are included in an area about 1,000 feet long and several hundred feet wide, trending N. $75^{\circ} \mathrm{E}$. The company's maps show that there were four main and several intermediate tunnels at different levels, aggregating more than 5,000 feet in length. Plate 6, drawn from a map dated March 1894 with some additions from later maps, represents nearly the entire workings. The stopes on it are necessarily generalized. As all underground workings in or near the lode are caved, the data on underground conditions given below are of necessity gleaned from Umpleby's description already referred to and from maps, letters, and reports in the mine office at Yellowjacket, kindly made available by Mr. E. M. Christiansen. Mention should be made of geologic sketch maps by T. H. Frances, April 6, 1915; J. B. Hastings, April 17, 1915; and O. Dupuis, December 1, 1916. In addition to the workings shown in figure 2, there is a 105 -foot doubletrack tunnel driven in 1923, known as the Peter tunnel, which was started near the mill with the object of tapping the ore bodies at depth.

\footnotetext{
${ }^{80}$ Umpleby, J. B., Geology and ore deposits of Lemhi County, Idaho: U.S. Geol. Survey Bull. 528, p. $170,1913$.
} 


\section{GENERAL GEOLOGY}

The country rock is dark-gray quartzite containing calcareous beds in places and belongs to the Yellowjacket formation. The attitude of the beds varies markedly in different outcrops, but in general they strike somewhat west of north and dip northeast. As is indicated on plate 1 , a normal fault which may have considerable displacement passes a short distance west of the mine. It strikes N. $30^{\circ}$ E. and dips northwest. The beds are much crenulated, have numerous joints, and probably are broken by many smaller faults. In the upper part of the open cut they strike N. $30^{\circ} \mathrm{W}$, and stand approximately vertical. It appears that small dikes of granophyre, granite porphyry, kersantite, and other rocks are numerous in the workings. Most of the dikes are believed to be later than the mineralization, but some, described as brecciated and altered, may be older. On the dump of tunnel 3 are pieces of altered igneous rock, which probably record the presence of dikes of Algonkian diabase in the workings tapped by this tunnel.

\section{STRUCTURAL RELATIONS OF THE LODE}

The lode comprises a great shatter zone containing numerous veins and stringers separated by more or less altered quartzite. The zone trends N. $65^{\circ}-75^{\circ} \mathrm{E}$. and appears to dip very steeply northwest, to judge by the stopes. The geologic sketch maps referred to above appear to indicate that there are two sets of more or less welldefined veins, one striking northwest and the other northeast. The faults indicated on these maps do not seem to be of large displacement. Umpleby ${ }^{51}$ says: "Two faults, both of which strike about N. $40^{\circ} \mathrm{W}$. and dip southwest, have been encountered in the mine. The western fault throws the vein 175 feet west on the east side, and the eastern is said to cause a further displacement to the west of 90 feet." Sheldon, ${ }^{52}$ who was one of the officers of the mine in the early nineties, says that the ore body mined on top of the ridge was from 200 to 300 feet wide, 40 to 80 feet thick, and ceased at a depth of 150 feet. About 600 to 800 feet to the west, down the hill, was a large body of white quartz, 40 to 50 feet wide, averaging $\$ 8$ to $\$ 9$ a ton, running nearly parallel to the vein found on the ridge. A tunnel was driven into the hill 200 feet vertically below the workings just referred to, but no ore had been found on that level at the time of his writing (1912). This is tunnel 3 of plate 6 . He suggests that the failure to discover ore at this depth may have been due to faulting but gives no direct evidence in support of this idea. In conformity with his statement that no ore was found below the old upper workings, plate 6 indicates that no stoping was done below tunnel 2. The section given in figure 24 of Umpleby's report shows a small amount

s1 Umpleby, J. B., op. cit. (Bull. 528), p. 170 and fig. 24.

s2 Sheldon, G. L., op. cit., p. 222. 
of stoping down to an intermediate level about halfway between tunnels 2 and 3 , but still 100 feet above tunnel 3 . An editorial note following Sheldon's article says that the faulted vein had been found but was again displaced by a gabbro dike. Some ore was later found, for Dupuis in 1916 records assays of five samples taken in a raise over the first long crosscut to the south off tunnel 3 at 2- to 4foot intervals from 4 to 12 feet above the crosscut. The samples ranged in value from traces of gold and silver in the sample taken 4 feet above the crosscut to $\$ 12.80$ in gold and 7.28 ounces of silver to the ton over a width of 30 inches 12 feet above the crosscut. In this same crosscut a body of galena ore was found by J. B. Hastings in 1914. The location is shown in plate 6 . This is the only place in the mine where any considerable quantity of base-metal ore is known to have been found, although there are rumors that such ore was encountered in various other parts of the workings. This ore lies essentially in the downward projection of the ore mined above tunnel 2. Its presence in this position, 200 feet below most of the stopes and 460 feet below the highest open cut, together with the obviously erratic deposition of ore as indicated in the open cuts, throws doubt on the cutting off of ore shoots by notable faults. Some faults doubtless exist, but in future development work the possibility should be borne in mind that the lack of downward persistence of the ore bodies may be due to an original discontinuity of premineral fissures and to consequent or independent irregularities in both hypogene and supergene mineralization. The shoots mined in the upper workings may have pitched west-southwest at small angles and may represent only uneroded remnants of much larger shoots. If something of this sort is true, it is possible that ore shoots as large as those already mined may exist in the lode at some place not yet penetrated by mine workings. However, as oxidation doubtless raised the ratio of gold in the ore of these upper workings, it is probable that ore bodies at depth would have a lower gold content.

\section{CHARACTER OF THE ORE}

In the open cuts still accessible numerous stringers and irregular bunches of quartz with some chlorite and less commonly of impure rusty calcite cut the quarzite. There are two distinct kinds of quartz. One kind forms irregular crusts composed of small crystals. The other is dull white and massive and forms gash veins and rounded masses. The remaining veins are rarely more than a foot or so wide but doubtless were wider in the material mined. The quartzite is weathered and iron-stained. Much of the vein quartz is also ironstained and contains rusty cubical cavities. In places there are considerable masses of limonitic material. Evidently the vein quartz and probably also the adjoining quartzite originally contained much pyrite. Copper stains are present in places but are nowhere abundant. 
It appears both from the exposures in the open cuts and from descriptions of the ore mined in the early days that it was a free-milling, thoroughly oxidized gold ore in which the principal hypogene sulphide had been pyrite. Copper and lead minerals were scant. Umpleby estimated that the average ore had a value of about $\$ 8$ a ton, mainly in gold. Sheldon said that the ore treated in the old mill averaged $\$ 9$ a ton and that the tailings averaged $\$ 1$ a ton. The tailings from the new mill, built in 1894, contained only 50 cents a ton, according to him.

The small amount of ore on the dump of tunnel 3, reported to have come from the crosscut off that tunnel above referred to, is of a totally different character. It consists of massive galena, with some chalcopyrite and pyrite in quartz. Mr. Christiansen states that one sample of this ore contained 51 percent of lead and 15 ounces of silver and $\$ 1.80$ in gold to the ton and that later samples were even richer. Definite data as to the quantity of such ore found are lacking, but it appears that little if any of it was shipped or treated. This ore is more nearly like the ore common in the mines of the region than that mined here in the early days. It may be that if a new ore shoot is found at depth in the Yellowjacket mine it will prove to contain galena-chalcopyrite ore instead of the auriferous pyritic ore that cropped out and was mined in the early days.

\section{COLUMBIA MUNE}

The workings of the Columbia mine cover a large area near the head of a western tributary of Yellowjacket Creek, a mile west of Yellowjacket. Most of them have long been inaccessible, but the numerous portals and moderately large dumps show that development was considerable. Umpleby ${ }^{53}$ estimated the total length of the tunnels to be 1,800 feet, which is conservative. The principal tunnels are at altitudes of 6,500 to 7,000 feet, but there is another at an altitude of about 6,100 feet. This was intended to cut the ore at depth, but, although reported to have been driven about 1,700 feet, it encountered no ore. Doubtless this tunnel, which was driven about 1903, was not included by Umpleby in the workings of the Columbia mine on which he gave the above estimate.

The best published description of the Columbia mine is that of Eldridge..$^{54}$ The following data are abstracted from that description, supplemented by what can be gleaned from inspection of the dumps. The country rock is dark-gray quartzite of the Yellowjacket formation, cut by several dikes of different kinds. The principal mineralized zones strike N. $60^{\circ} \mathrm{E}$. and dip $30^{\circ}-70^{\circ} \mathrm{W}$. They range in width from

s Umpleby, J. B., op. cit., p. 172.

u Eldridge, G. H., A geological reconnaissance across Idaho: U.S. Geol. Survey 16th Ann. Rept., pt. 2, pp. 262-264, 1895. 
a few feet to 50 feet or more. A subordinate set of fracture zones strike N. $15^{\circ}-25^{\circ} \mathrm{W}$. The fracture zones contain brecciated gray quartzite cemented by quartz. Sulphides are irregularly distributed both in the vein quartz and replacing the quartzite fragments. The ore resembles that of the Continental prospect and like that contains chalcopyrite, pyrite, and probably tetrahedrite and calcite. Eldridge says that the value of the average ore was reported to be $\$ 30$ a ton and that the maximum value was $\$ 150$ a ton. Like all other ore of the district, it carried a considerable part of the value in gold. The sulphides near the surface were more or less oxidized, affording a freemilling ore, and it was reported to Eldridge that more or less free gold occurred in the unaltered portions also. Oxidation does not appear to have penetrated to any considerable depth and even near the surface is not complete.

\section{RED JACKET PROSPECT}

The Red Jacket prospect is about $1 \frac{1}{2}$ miles north of the town of Yellowjacket. It was discovered about 1866 , and considerable development work is reported to have been done in the nineties. According to report the ore was free-milling and contained no base metals, but Umpleby ${ }^{55}$ notes that the ore on the dumps of the two tunnels consisted of "coarse quartz enclosing pyrite, chalcopyrite, sphalerite, and galena, decreasingly important in the order named. Oxidation is apparently slight in the deposit." Some of the ore is reported to have contained as much as $\$ 38$ a ton in gold, but none appears to have been milled. Operations ceased about 1903. The property was not visited during the present investigation.

\section{COPPER GLANCE PROSPECT}

The Copper Glance prospect is on the Yellowjacket Creek slope of the ridge between that stream and Trail Creek. It is near the top of the ridge, at an altitude of about 7,400 feet, and is reached from Yellowjacket either by a trail up Trail Creek or by road to the mouth of Anderson Creek and thence by trail up the slope to the prospect. The prospect is owned by J. E. and C. C. Anderson. It was discovered in 1901. As can be seen from figure 3, the developments include a tunnel about 305 feet long, with 2 short drifts and 3 small stopes; also a shaft about 30 feet deep with its collar 75 feet above the tunnel portal. No ore had been shipped up to the time of visit in June 1926, but 12 tons was stored in sacks on the tunnel dump ready for shipment.

The country rock is dark-gray quartzite of the Yellowjacket formation cut near the portal of the tunnel by dikes of altered lamprophyre.

${ }^{5}$ Umpleby, J. B., op. cit., p. 172. 
As is indicated in figure 3, the attitude of the quartzite beds varies markedly. This results largely from displacement along slips, many of which are so small and discontinuous that they were not mapped. The ore is in discontinuous masses, bounded for the most part by slips. It was formed in fracture zones, in part by filling of open spaces, in part by replacement of the quartzite. Some movement has taken place subsequent to the ore formation.

The hypogene metallic minerals include chalcopyrite, tetrahedrite, pyrite, and galena, and the gangue minerals are quartz and siderite. The siderite generally forms an irregular border between the quartz and country rock and merges into the country rock by replacement. In places it is intimately intergrown with the vein quartz. The quartzite near the ore masses is bleached and even at some distance

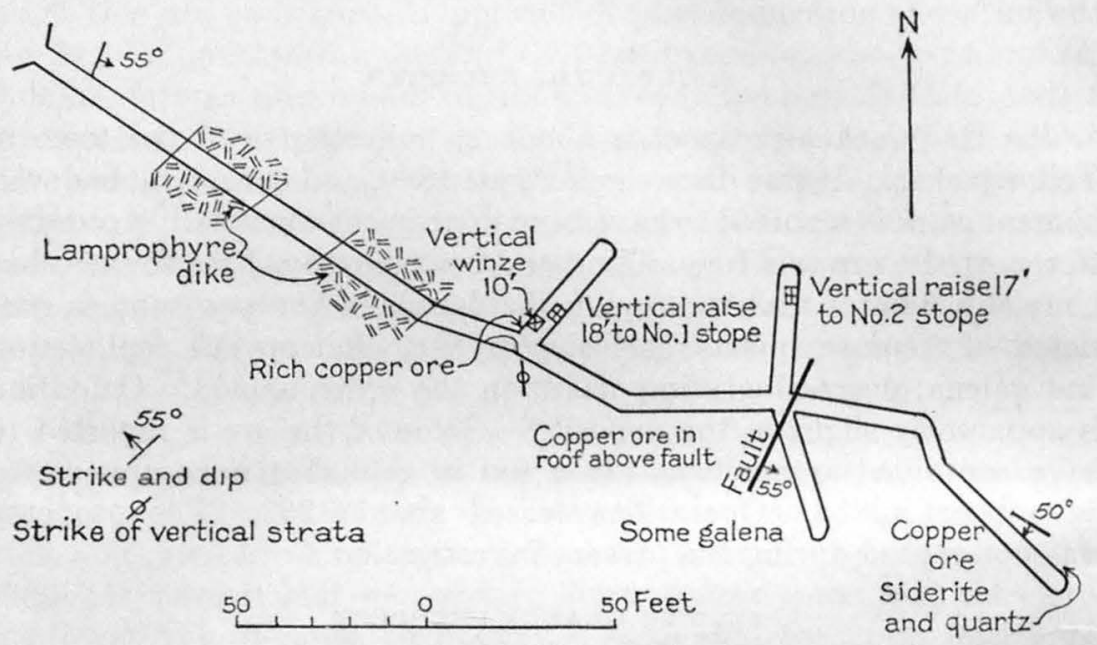

FIGURE 3.-Sketch map of the Copper Glance tunnel.

appears to have been hydrothermally altered and contains oxidized pyrite. The ore sorted for shipment consists largely of massive chalcopyrite and tetrahedrite and according to J. E. Anderson contains an average of 26 percent of copper, 40 ounces a ton in silver, and $\$ 10$ a ton in gold. Some of the ore mined carries 5 to 7 percent of lead.

The results of supergene alteration are marked throughout the workings. Much of the siderite has been oxidized to a soft limonitic material, and the copper minerals are partly oxidized to chrysocolla, malachite, and azurite. Even the massive, comparatively fresh-looking chalcopyrite is reticulated with seams containing copper pitch ore, chalcocite, and covellite.

\section{OHIO PROSPECT}

The Ohio prospect, outside of the limits of the Casto quadrangle, is about 2,000 feet southeast of the Copper Glance prospect, on the 
same ridge, and is also owned by the Anderson brothers. Work began in 1902, and the principal development is a tunnel about 200 feet long, which traverses a fracture zone about 150 feet wide in quartzite, in which the closely spaced fractures are filled with narrow veinlets of quartz and rusty siderite studded with rusted pyrite. The zone strikes a little east of north and appears to dip steeply west. Stains of iron and manganese oxides are abundant, especially along cracks. Near the portal the quartzite beds strike N. $8^{\circ} \mathrm{W}$. and stand essentially vertical. At the face a greenish altered granitic rock is exposed. J. E. Anderson states that the material in the fracture zone contains an average of about $\$ 8$ a ton in gold, the best ore being found where the rock is most rusted.

\section{CON'TINENTAL PROSPECTS}

On the slope immediately west of the town of Yellowjacket there are a number of claims owned by Mrs. H. F. Steen, which may be collectively referred to as the Continental prospects, from the claim on which the largest accessible workings are situated. The patented claims of this group are the Continental, Broken Hill, Lincoln Fraction, and Red Bird. The deposits here have been known since 1891 or before, but the work done on them has been meager. There are several tunnels on this and adjoining properties, but all are short and most are caved. There has been very little production. Some work has been done here since 1930 .

At the time of visit (June 1926) work was in progress at the Continental tunnel. The portal of this tunnel is at an altitude of about 6,550 feet. It is about 500 feet long and has two short branching drifts off it. The country rock is dark-gray quartzite of the Yellowjacket formation, in part calcareous, broken by numerous slips and breccia zones. The quartzite throughout is more or less shattered. Bedding, veins, and slips in general have an average northeast trend, but there is much variation in the attitude of all three. The slips probably marked renewed movements on premineral lines of weakness, but the major shattering preceded the mineralization. Near the portal there is a small dike of highly kaolinized porphyry, which has been faulted. Throughout the workings there has been scattered mineralization, but no well-defined vein of any size was encountered, and in most places the amount of sulphide is small. The ore consists of veinlets of quartz with some calcite and breccia zones in which the quartzite fragments are cemented by quartz and calcite. The quartzite is somewhat chloritized, especially along some of the slips, and locally is partly replaced by calcite. Generally in the veins containing both calcite and quartz the calcite lies along the walls and the quartz in the middle. Pyrite, chalcopyrite, and some galena and tetrahedrite were noted but are nowhere abundant. Most of the 
sulphides are in the vein quartz. Oxidation is evident throughout the workings, but much of the original sulphide remains unaffected. Supergene iron and manganese oxides, malachite, chrysocolla, and aragonite are present. Supergene sulphides, if present, are not sufficiently abundant to be noted. The ore is considered to be principally valuable for its gold content, which is reported to be greatest where the manganese oxides are most abundant.

The caved Broken Hill discovery tunnel, originally 25 feet long, is about 500 feet vertically above the Continental tunnel. An outcrop 10 feet above the portal consists of calcareous gray quartzite which strikes about $\mathrm{N}, 40^{\circ} \mathrm{E}$. and stands essentially vertical. The beds are crinkled and fractured, and some of the fractures are filled with quartz and calcite veinlets, with iron oxides, malachite, chrysocolla, a little azurite, very little galena, and some cerusite and anglesite.

The workings of the Lincoln Fraction are on the top of the ridge at an altitude of about 7,000 feet. They consist of a partly caved shaft reported to have been 100 feet deep and a shallow open cut. Probably no work has been done here for 20 years. On the shaft dump there is very rusty quartz containing malachite, azurite, and rather coarsely crystalline galena. The ore is reported to have contained $\$ 10$ to $\$ 14$ a ton in gold. At the open cut rusty veinlets of quartz with some calcite cut gray quartzite. There is a pile of sorted ore reported to be free-milling and to average $\$ 12$ a ton in gold.

\section{BLACK EAGLE MINE}

The Black Eagle mine is on the most easterly branch of Hoodoo Creek at an altitude of 7,450 feet, about a mile north of the boundary of the Casto quadrangle. It is connected with Yellowjacket by a road about 4 miles long. The road is now in disrepair but could be put in condition for use at small expense. The property comprises three claims patented in 1909 and two or more unpatented claims. There is a 15-stamp mill and several cabins. The developments comprise six tunnels and several cuts. The tunnels near the mill, the only ones visited, are caved. A small shipment of high-grade gold ore was made in 1922. The production of the mill is unknown but probably not large. When visited in August 1926 the property appeared to have been deserted for some time.

The rock at the property is white Hoodoo quartzite. The dump of the principal tunnel is largely composed of this quartzite, but most of the ore on the dump is in a highly metamorphosed gabbro, now a dark-green chloritic schist. Fractures in this schist are filled with massive white quartz with siderite, pyrite, specularite, and some calcite. Specularite lines some of the joint faces in the white quartzite.

Umpleby ${ }^{56}$ notes that "the ore is coarse quartz with pyrite, manganite, chalcopyrite, and a little sphalerite, scattered irregularly and

80 Umpleby, J. B., op. cit., p. 172. 
generally sparsely through it. As exposed [at the time of Umpleby's visit] the vein varies from a stringer up to 5 feet, averaging perhaps 6 inches. It is worked for gold."

\section{LOON CREEK DISTRICT}

\section{LOCATION AND EXTENT}

The Loon Creek district covers an area of nearly 50 square miles in the southwestern part of the quadrangle. Its limits are indefinite, but the district may be considered to include that part of the drainage basin of Loon Creek between the mouths of Cottonwood and Mayfield Creeks and the lower part of the valley of Mayfield Creek. It contains the old towns of Casto and Ivers, now nearly deserted most of the year. Ivers once contained several hundred people, but in recent years it has rarely contained more than half a dozen. The district is reached by an automobile road that leaves the Salmon River at the Sunbeam Dam, passes through Bonanza, and crosses the Loon Creek summit to Ivers. The distance from the Sunbeam Dam is a little less than 35 miles. The road over the summit was reconstructed in 1927 and 1928 and aids materially in travel to the district by lessening the grade and keeping open for a longer time. Snow on the summit formerly kept the road closed from November or earlier until late June or early July.

\section{HISTORY}

The placer deposits on Loon Creek near Casto were discovered about 1869 by prospectors from the Yankee Fork district. They were worked for about 10 years, and most of the production was obtained during the first half of this period. Toward the end of the period the only miners remaining were a group of Chinamen, whose number is variously estimated at 30 to 60 . In the winter of 1879 they were massacred by a band of Indians or of white men disguised as Indians. Since then there have been several attempts to rework the placers and to mine gravel higher on the slopes than that attacked by the early miners, and a small production has been obtained. The placers have now been idle for many years. According to Umpleby ${ }^{57}$ the total production from these deposits has been variously estimated between $\$ 500,000$ and $\$ 2,000,000$.

There appears to have been little lode mining in the district until 1902, when the Lost Packer gold-copper lode was located by Clarence E. Eddie. This lode is named for a packer who, in 1866 or thereabouts, lost his way in this region and, while lost, stumbled on the outcrop of a promising-looking lode. The property was purchased by Ivers \& Finlan, of Salt Lake City, who began development in 1904. A 100-ton matte smelter was completed in 1905 and was operated for

\footnotetext{
57 Umpleby, J. B., A preliminary account of the ore deposits of the Loon Creek district: U.S. Geol. Sur-
} vey Bull. 530 , p. 66,1913 . 
short periods in 1907, 1908, 1911, and 1914. At first transportation between the mine and Bonanza was effected by pack train. Coke was hauled to the mine and matte from the mine over 110 miles of mountain road to the railroad at Mackay. In spite of this long haul and of numerous metallurgical difficulties the returns from these runs permitted consistent development of the mine to be carried on throughout this period. A concentrating mill was completed early in 1916 and operated in 1916 and 1917. After that little work was done until the summer of 1926, when the lowest tunnel was reopened and search started for ore lost in the workings above. This work was continued in 1927.

Umpleby ${ }^{58}$ states that the production up to the time of his visit in 1911 was estimated at $\$ 500,000$, and James Ivers, in charge at the time of the writer's visit, thought that about $\$ 100,000$ had been produced since then.

The Lost Packer lode is the only one of its type in the district that has produced much ore. There are several openings in a similar lode just west of it, but most of these are now caved, so that the deposit could not be examined. On the south side of Canyon Creek about a mile farther southwest there are caved tunnels, apparently long abandoned. They appear to have followed gash veins of quartz with chalcopyrite in schist and quartz monzonite. The Sunrise and other prospects, most of which are held for their content of lead and silver, are south of the Lost Packer, chiefly near the head of Deer Creek. Little is known regarding the history of these prospects except that they have changed hands several times, are little developed, and have produced little ore. Annual assessment work is still maintained on several of them in the hope that improvement in transportation facilities will render it feasible to develop them. There are also a few prospect pits north and west of Pinyon Peak. Work on the Monte Cristo mine, on Mayfield Creek, was started in 1917, and a little work has been done in most years since then, principally in the summer.

\section{PLACER DEPOSITS}

The only placer deposits in the Loon Creek district that have been worked to any extent are on Loon Creek, from a point a short distance above the old town of Casto down to a point near the mouth of Shell Creek, a distance of about $4 \frac{1}{2}$ miles. They have an average width of roughly 1,000 feet and comprise the elevated flood plain of Loon Creek and terraces that rise 100 feet or more above the present channel. According to Umpleby, ${ }^{59}$ the part worked in the early days was a strip about 75 feet wide and 1 mile long, comprising the upper part of the central channel.

\footnotetext{
s8 Umpleby, J. B., Some ore deposits in northwestern Custer County, Idaho: U.S. Geol. Survey Bull. 539, p. $91,1913$.

so Umpleby, J. B., op. cit. (Bull. 539), p. 94.
} 
The ground is now held by the Loon Creek Hydraulic Placer Mining Co., which owns four claims. ${ }^{60}$ This company has a 4,000-foot timber flume, now in disrepair, a dam across Loon Creek, ditches, and buildings. Umpleby says that prospecting by this company during two seasons indicated that the terraces above the ground previously worked averaged 25 cents a cubic yard.

The gravel is moderately coarse and only moderately well sorted. Most of the pebbles in it are less than 6 inches in diameter, but many exceed a foot and some are more than 6 feet wide. The gravel on the terraces is rarely much over 20 feet thick, though in places thicknesses as great as 40 feet are exposed. Most of the gold, as usual, is near bedrock and in joints and shallow depressions in bedrock. It is characteristically coarse. Umpleby says that nuggets weighing more than an ounce are not uncommon, "and perhaps 50 percent of the product averages 25 cents or more to the color. The market value is \$18 an ounce."

\section{LOST PACKER MINE}

LOCATION

The Lost Packer mine is in a gulch tributary to Canyon Creek on the north side of the old town of Ivers. The mill and smelter are just below the lowest mine tunnel, at the east end of the town.

\section{DEVELOPMENT}

The Lost Packer property comprises eight claims, two of them fractional, and includes most of the town of Ivers. Below the lowest mine workings are a small concentrating mill with a cyanide plant and a 100-ton matte smelter with a hydroelectric power plant. In the recent work electricity has not been produced, but water power has been used to compress air for the mine drills.

The underground development is on 10 levels, extending over a vertical distance of about 940 feet. Of these levels 8 are tunnels from the surface and 2 are blind levels on which comparatively little work has been done. The lode appears to continue about 100 feet above the workings, to the point where it is cut off by Oligocene (?) lava. Only the third and tenth tunnel levels and parts of the fourth, sixth, and seventh were accessible when visited in the summer of 1927 . A sketch map of these parts of the workings is shown in plate 7. The extent of the original workings is shown in figure 4, reproduced from Umpleby's report. This shows that the mine contains over $1 \frac{1}{2}$ miles of drifts. In the recent exploration the branching drifts at the end of tunnel 10 , shown in plate 7 , have been driven, and the parts of the upper tunnels now accessible have been cleaned out.

\footnotetext{
Campbell, Stewart, Twenty-eighth annual report of the mining industry of Idaho, for 1926, p. $118,1927$.
} 


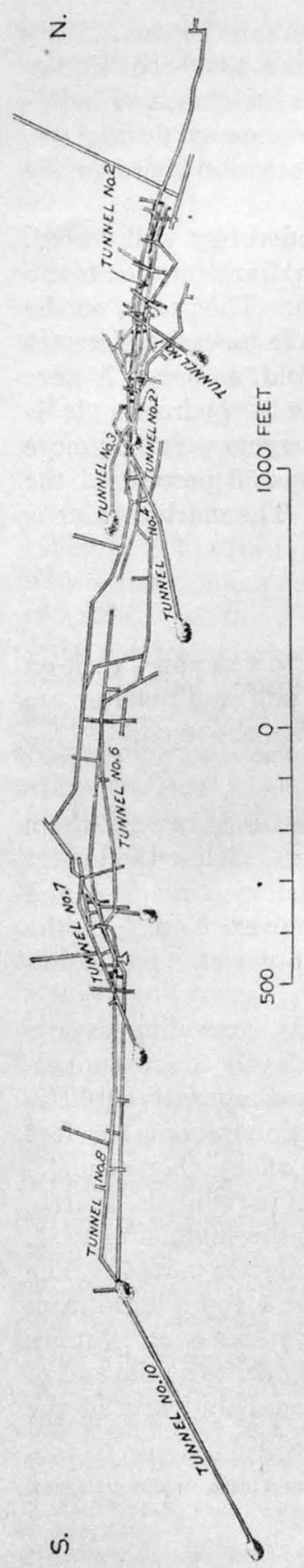

\section{GENERAL GEOLOGY}

The lode is in a block of Algonkian schist flanked and intruded by various igneous rocks and capped on the ridge crest by flows belonging to the Challis volcanics. The broader features of the geology are shown on plate 1 , and such details close to the lode as could be discerned are shown in plates 7 and 8 .

The rock east of the schist is mainly dacite porphyry, but its relations are more irregular than could be indicated on plate 1 , and small amounts of other rocks are present in it. The relations on the west side of the schist are even more complex. The dacite porphyry there occurs as a group of closely spaced and extremely irregular dikes in granitic and aplitic rock related to the Idaho batholith and some small blocks of schist. The dike rocks vary more or less in texture and composition from the typical dacite porphyry.

The schist mass that contains the lode is both contorted and fractured. Its schistosity, especially in tunnel 10 , generally strikes northwest and dips steeply southwest, with much variation. At higher altitudes strikes of N. $60^{\circ} \mathrm{E}$. and N. $70^{\circ} \mathrm{E}$. were observed. The composition of the schist is described on page 22 .

In the schist there are various intrusive masses of aplitic rocks, dacite porphyry, coarsely porphyritic granophyre, and altered lamprophyre. The aplite varies considerably in texture and composition, grading toward quartz monzonite of the Idaho batholith on the one hand and into pegmatite on the other. The typical aplite is moderately fine grained, is nearly white, and contains quartz, microcline, sodic plagioclase, muscovite, and locally small amounts of biotite. It is now markedly sericitized and kaolinized. It forms irregular masses, dikes, and stringers, which both follow and cut across the planes of schistosity. 
The extreme pegmatitic facies is represented by irregular veins of glassy quartz containing some mica and flakes of molybdenite. These are somewhat later than the aplite and cut both aplite and the adjacent schist. The best exposure noted is in tunnel 10 about 1,200 feet from the portal. Here the quartz vein attains a maximum width of 18 inches.

The lamprophyre is represented by two dikes of altered green fine-grained rock with scanty small feldspar phenocrysts in tunnel 3 and by stringers of similar rock near the end of tunnel 10. Smaller stringers were seen in a few other places. The rock has been altered to a mass of chlorite, sericite, and clay minerals with some residual feldspar and a little introduced quartz and carbonate. Its general appearance and the faint traces of its original texture favor its correlation with lamprophyres related to the Idaho batholith. It cuts aplite but is more altered than the other dike rocks.

The dacite porphyry and granophyre (called diorite porphyry and granite porphyry by Umpleby ${ }^{61}$ ) are typical of these types throughout the quadrangle. (See pp. 62-64.) They are more or less kaolinized in the vicinity of the lode. Both these porphyries, as Umpleby noted, appear to cut the lode. Observations elsewhere confirm his conclusion that the granophyre is the younger of the two and show that both are probably Miocene. The only granophyric mass mapped in this vicinity is a clean-cut, steep-sided dike, but the dacite porphyry forms very irregular masses, whose walls are curved and change their inclination from nearly horizontal to nearly vertical within distances of only a few feet. Some idea of the irregularities can be gained from plate 7 , especially along tunnels 6 and 7 and the adjacent surface.

\section{FAULTING OF THE LODE}

Postmineral disturbance has been limited to minor faulting and fracturing along the lode and, at a few places, across it. This statement is contrary to the general assumption by those familiar with the mine that the steplike arrangement of the ore shoots is due to the displacement of a once continuous ore body along faults that are now filled with porphyry dikes. It is true that some ore shoots are abruptly interrupted or terminated by dikes that dip at various angles (pl. 7), but the observed relations can be explained by intrusion without previous faulting. The steplike arrangement of the ore shoots, as already pointed out, is an original feature, and at several places they feather out where neither fault nor dikes are present.

There are several postmineral slips in tunnel 10, and one of them, of northwesterly trend and about 250 feet from the breast of the tunnel, is of particular interest, as fragments of chalcopyrite ore

ot Umpleby, J. B., op. cit. (Bull. 539), pp. 92, 93. 
similar to that of the middle ore shoot are said to have been found in it. This shoot, the largest in the mine, is said to have been cut off by a dacite porphyry dike a short distance below tunnel 7 , and its downward continuation was supposed to have been offset to the east. It has been sought at greater depth only through tunnel 10, which passes about 50 feet east of the position of the middle shoot on level 7 and was unsuccessfully planned to intersect the supposed faulted continuation. A west crosscut to a point about 40 feet west of the vertical projection of the shoot on level 7 was also unsuccessful. As the middle shoot has already been mined through a vertical distance of more than 700 feet, which compares favorably with the vertical dimensions of chalcopyrite deposits in shear zones, it may well have pinched out above tunnel 10; but the fragments of ore in the slip in this tunnel suggest that it may be nearby. The slip, which bounds one side of a fault block of dacite porphyry, is almost directly beneath the middle shoot, and its dip parallels the pitch of the shoot. A raise along this slip, with drifts along it at intervals between levels 10 and 7 , appears more likely to lead to ore than any of the work done thus far on this part of level 10.

Small amounts of chalcopyrite and siderite are reported to have been found in the most northerly and easterly branches of tunnel 10 before the writer's visit, and a body of chalcopyrite ore, without gold, has since been exposed. Several slips striking approximately parallel to the lode are present here, and the rocks for 100 feet or more from the face (shown in pl. 7) are much disturbed. This disturbance proves the occurrence of shearing and mineralization similar to those that have affected the lode on the upper levels. The position of this body and the reported lack of gold suggest that it is an extension of the north shoot or a parallel lens. Such parallel zones are common in lodes of this type and are known to exist here. Umpleby ${ }^{62}$ notes the presence of chalcopyrite lenses 20 feet from the main lode in the upper levels. A similar and parallel lode has been partly developed a few hundred feet west of the Lost Packer mine in property formerly owned by the late E. W. Garrettson.

\section{THE ORB}

Chalcopyrite is the dominant metallic mineral, but small amounts of tetrahedrite and pyrite were also found, and Umpleby notes the presence of a little pyrrhotite. Jennings ${ }^{63}$ and Umpleby note the presence of bornite, native copper, and oxidized copper and iron minerals near the surface. The principal original gangue minerals are vein quartz, siderite, and the minerals of the sheared and altered schist and aplitic dikes. A little calcite is present, and Jennings

62 Umpleby, J. B., op. cit. (Bull. 539), p. 96.

w Jennings, E. P., The Lost Packer copper-gold lode: Canadian Min. Inst. Jour., vol. 9, p. 56, 1906. 


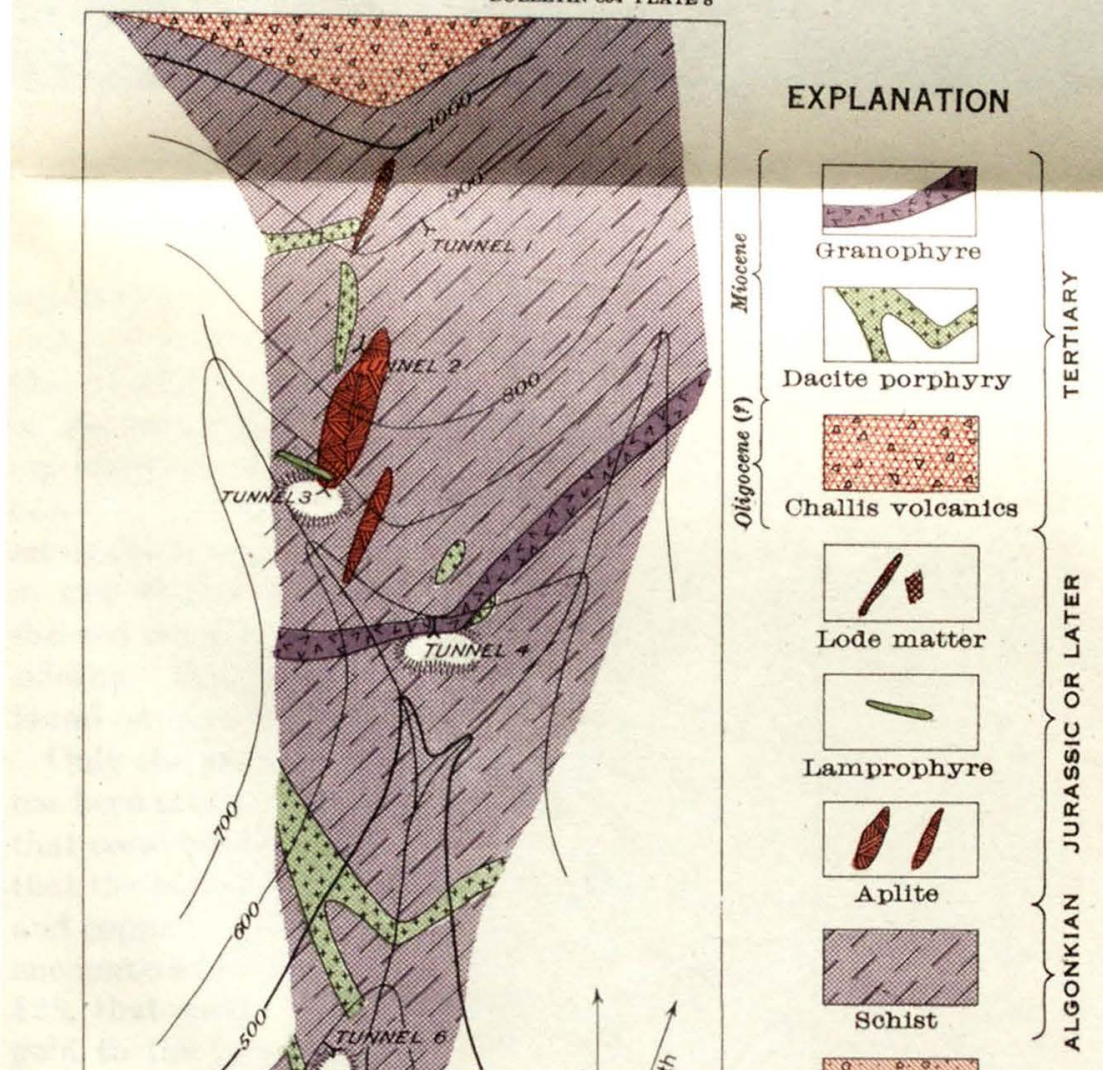

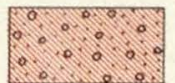

\section{Detritus}
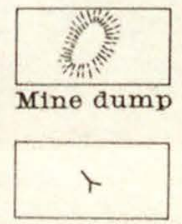

Tunnel portal

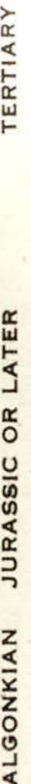

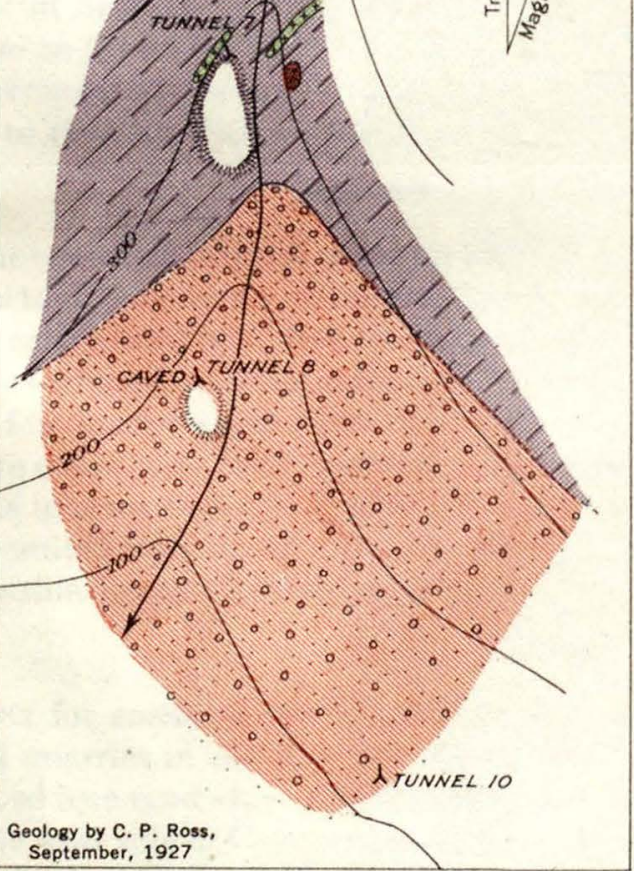

GEOLOGIC MAP OF

THE LOST PACKER MINE, IDAHO

$0 \quad 500$ Feet

Contour interval 100 feet 

reported barite also. The relative abundance of siderite and quartz varies in different parts of the lode: material on the dumps indicates that where one is abundant the other is scanty. Umpleby states that in the south shoot siderite predominates, whereas in the other two, especially the middle one, quartz is the more abundant. Siderite is, however, generally present in greater or less abundance in most of the mineralized parts of the lode. Both the siderite and the quartz occur in two ways - in lenses of vein matter and in grains impregnating sheared country rock. This is especially striking in the case of the siderite. Specimens that at first glance resemble ordinary schist are found on examination to be more than 50 percent siderite.

Only the high-grade ore, consisting largely of massive chalcopyrite, has been sought, and most of this ore has been stoped; but it is reported that considerable quantities of low-grade ore remain. Umpleby says that the high-grade ore mined ran $\$ 80$ to $\$ 90$ to the ton in gold, silver, and copper. He adds that for every ton of this grade which has been encountered in the mine there is estimated to be $2 \frac{1}{2}$ tons which average $\$ 25$, that assays of the chalcopyrite usually show $2 \frac{1}{2}$ to 3 ounces of gold to the ton, and that the quartz, especially that of the middle shoot, is equally rich in gold. He says further that the siderite as a rule does not contain more than half an ounce of gold to the ton and that "in both the chalcopyrite and the quartz silver runs about $2 \frac{1}{2}$ ounces to the ounce of gold." Jennings estimates that the high-grade ore averages 15 percent of copper and contains from 2 to 20 ounces of gold to the ton, with a small amount of silver.

OXIDATION AND ENRICHMENT

The effects of surficial water on the lode have not been economically important. Jennings estimates that the zone in which oxidation has been active is 30 to 40 feet thick, but in places primary sulphides close to the surface show little oxidation. Evidence of enrichment is limited to a few places where films of bornite coat chalcopyrite and a little native copper has been reported. Kaolinization, which is widespread in the igneous rocks, including the postmineral porphyries, doubtless has resulted from the effect of descending water rendered acid by incipient oxidation of sulphides near the surface.

\section{FLUX QUARRIES}

Flux for smelting the Lost Packer ore was obtained from several small quarries in the Paleozoic limestone south of Ivers. They were reached by a road about 2 miles long which circles around the mountain on the west side of Canyon Creek into the valley of Deer Creek. The largest quarry is in the marble about a mile south of Ivers. Another is in calcareous strata at the end of the road just beyond Deer Creek. There are several smaller excavations at other points along the road. 
The rock has been described and analyses of it given on pages 24, 69-72. It is in part a rather coarse marble, in part impure and dolomitic limestone, which has been partly replaced by contact-metamorphic silicates. It contains in places small quantities of pyrite, löllingite, and probably pyrrhotite, all of which are now more or less completely oxidized. Umpleby ${ }^{64}$ says that the rock quarried as flux contains about 60 cents in gold and 1 ounce of silver to the ton-almost sufficient to pay the handling costs.

\section{PROSPECTS NEAR THE HEAD OF DEER CREEK}

In the basin at the head of Deer Creek and on the ridge between Deer and Canyon Creeks there are several cuts, shallow shafts, and short tunnels, mostly in poor condition. When this area was visited in the summer of 1925 no work was in progress except at a small sawmill connected with the Metcalf group. The Sunrise mine, or prospect, shown on plate 1, appears to belong to this group. The Lost Eagle property is on the ridge a short distance farther west. The workings at these properties were evidently more accessible when Umpleby ${ }^{65}$ visited them in 1911 than they were in 1925 . The following notes are abstracted from his description, supplemented by the scanty data obtained during the present investigation.

The Lost Eagle claim is in schist, cut by porphyry dikes. Development in 1911 consisted of a shaft 50 feet deep and a short drift from it. A freshly made tunnel 20 feet long was noted in 1925 on what is believed to be this property. According to Umpleby the lode strikes N. $5^{\circ}$ W., dips $85^{\circ} \mathrm{SW}$, and is about 6 feet wide, with well-defined walls. The lode matter is "crushed wall rock with bands and interstitial areas of argentiferous galena, pyrite, and a little chalcopyrite in a quartz-siderite gangue." The lode which Umpleby describes as the Metcalf is evidently that mapped on plate 1 as the Sunrise. The Metcalf or Sunrise lode, according to Umpleby, is "an irregular vein partly developed for 100 feet along its outcrop." He interpreted it as a fissure filling in granitic rock near the contact with dolomitic limestone, and said: "The ore consists of argentiferous galena, which fills the fissure almost exclusively and ranges in width from a narrow stringer in most places to $3 \frac{1}{2}$ feet in other places. The galena contains about 1 ounce of silver to the unit of lead." Three partly caved tunnels and a shallow shaft were noted here in 1925 . The dumps showed rusty and altered granitic rock, altered dolomitic limestone, and marble, the marble containing contact-metamorphie minerals. A little massive siderite was noted. Metcalf, who died in 1926, had other prospects in this vicinity.

or Umpleby, J. B., op. cit. (Bull. 539), p. 93.

os Idem, p. 99. 
A short distance southwest of the Sunrise, close to one of the branches of Deer Creek, there are four cuts following irregular veins of glassy quartz with pyrrhotite in quartz monzonite. The uppermost of these cuts is in a pyroxenite dike with disseminated pyrrhotite.

\section{MONTE CRISTO MINE}

The Monte Cristo mine is on the north side of Mayfield Creek near its mouth. The property comprises 10 unpatented claims. ${ }^{66}$ The cabin is on the south bank of the creek about $1 \frac{1 / 4}{4}$ miles above its mouth. The lower tunnel is about 1,700 feet above the creek, and the upper one is due north of it and roughly 200 feet higher. The recent work has been confined to the lower tunnel, which at the time of visit, June 30,1925, was somewhat over 700 feet long. This tunnel trends north for most of its length, but the inner 120 feet swings somewhat to the east. The upper tunnel trends N. $30^{\circ} \mathrm{W}$. near the portal but is caved a short distance in. There are other pits or trenches on the property. The country rock is gray to greenish chlorite schist. About 300 feet from the portal of the lower tunnel is an irregular fine-grained rusty felsite dike trending northeast. The upper caved tunnel is reported to contain the ore body that is to be intersected by the lower tunnel. Some of the rock on the uppertunnel dump has vugs containing quartz crystals. No ore was seen, although small amounts are reported to have been shipped from the property.

\section{SCATTERED PROSPECTS IN DEPOSITS PROBABLY OF MESOZOIC AGE}

\section{MINERALIZATION NEAR SLEEPING DEER MOUNTAIN}

There has been some prospecting in the area around Sleeping Deer Mountain. Vein matter containing galena, chalcopyrite, pyrite, and other metallic minerals has been found, but no development other than shallow cuts has been attempted. According to report the principal discoveries are near the head of one of the forks of Liberty Pole Creek, on both sides of Woodtick Creek near its head, and on the upper reaches of Grouse Creek. The only places where evidence of mineralization was noted in this area during the present investigation are the two mentioned on page 98 . Of these, the prospect above Cabin Creek was opened by R. L. Falconberry, because the black schist there looked to him like a rock favorable to mineralization, but he abandoned it without finding any sulphide. The gash veins on the west side of Woodtick Creek are almost untouched and do not look sufficiently promising to warrant much development. It appears from report that the mineralization at places scattered over this general area has been sufficient to encourage prospecting when the area becomes

66 Campbell, Stewart, Thirtieth annual report of the mining industry of Idaho, p. 119, 1929. 
more accessible. Specimens of lead and copper ore have been found there.

"LOST CLEVELAND MINE"

One of the major incentives to prospecting in the area around Sleeping Deer Mountain has been the supposed presence there of what is locally termed the "lost Cleveland mine." The search for this supposed deposit has been carried on mainly by Mr. Thomas Martindale, who kindly furnished the data on which the following account is based.

In the late sixties a party of four prospectors, including a young man named Cleveland, made their way southwestward across country from Yellowjacket. While searching for his horses Cleveland found specimens supposed to have contained "black telluride." Two samples which were later assayed are reported to have showed $\$ 64,000$ and $\$ 48,000$ a ton in gold and silver, respectively. In 1903, on his return from a trip to the Thunder Mountain district, which was then booming, Martindale found Cleveland on Woodtick Creek. Cleveland had returned to look for the place his specimens came from but had been kicked and badly injured by one of his horses. Martindale nursed him back to health. Later the two spent three summers together in vain search for the deposit before Cleveland died. Martindale returned in 1915 and has devoted most of his summers since then to the task. He found several places where there appeared to be evidence of mineralization but nothing resembling the bonanza ore attributed to Cleveland. He states that one of his samples yielded, on assay, $\$ 5$ to the ton in gold and about $\$ 1$ to the ton in silver, lead, and copper. No telluride ore is known anywhere in the region, but as very rich ore is reported to have been found in the early days in the Gravel Range district to the east, it is possible that a pocket of similar ore was found by Cleveland.

\section{VALENTINE PROSPECT}

The Valentine prospect is on the east side of Loon Creek just below Cabin Creek at and above an altitude of about 5,500 feet. It was discovered February 14, 1907, by R. L. Falconberry, whose ranch is nearby. He did some work there in 1907 and 1908, but nothing has been done since then. The developments comprise a shaft, originally 17 feet deep, now nearly filled; a short tunnel, not found when the locality was visited during the present investigation; and some shallow cuts. At the shaft there is a seam striking N. $82^{\circ}$ E. and dipping $65^{\circ} \mathrm{N}$., in crushed and altered andesitic lava of the Casto volcanics. The seam contains a little vein quartz and small quantities of chalcopyrite, azurite, and malachite. 


\section{PARKER MOUNTAIN DISTRICT}

LOCATION AND EXTENT

The unorganized Parker Mountain gold-mining district occupies about 15 square miles in the southeastern part of the Casto quadrangle, comprising the drainage basins of Parker Creek, Kerr Creek, the unnamed creek just east of Kerr Creek, and the intervening part of Warm Spring Creek. It is reached by road and trail from Challis, a distance of about 30 miles. Only half the distance can now be traveled by a wheeled vehicle, owing to washouts, and it is doubtful if the road was ever sufficiently completed to allow vehicular traffic all the way except when deep snow was on the ground. There was a well-graded road, now washed out, from the mill at the mouth of Kerr Creek up that creek to the ore bins at the Parker Mountain mine, a distance of nearly 2 miles. The difference in altitude between the two ends of this short road is roughly 1,400 feet.

\section{HISTORY}

The Parker Mountain district is one of the most recently discovered districts in this part of Idaho. Evidence of mineralization was apparently first noted there in 1904. Some production of gold and silver was obtained in 1905-8, 1912, 1913, 1915, and 1926, mostly from the Parker Mountain and Williams properties. Definite data are not available for most of these years, but the total production probably does not greatly exceed $\$ 10,000$. The production in 1915 was obtained by reworking the tailings at the Parker Mountain mill, and that in 1926 was obtained from a pocket near the old Parker Mountain mine by George Kys and Joe Keyser. According to report, the quantity of ore removed from this pocket was so small that it was put in a Ford truck, but its value was about $\$ 800$, mostly in gold. Probably a considerable part of the earlier production came from similar small pockets.

The Parker Mountain and Williams properties, the only ones that have received any considerable amount of development, are described below. Numerous prospect cuts have been made elsewhere in the district, but apparently none disclosed showings sufficiently favorable to encourage development.

\section{PARKER MOUN'TAIN MINE}

The Parker Mountain mine is situated, as shown on plate 1, on a spur above the head of Kerr Creek, about 8,000 feet above sea level. The ore was sent in chutes to ore bins at the head of the road and thence in wagons to the 5 -stamp mill at the mouth of Kerr Creek.

The developments comprise the two tunnels shown in figure 5 and several cuts and trenches. The tunnels follow a well-defined shear zone in fractured, silicified, and kaolinized lava. The lava is too much altered for precise determination but is probably a latitic flow breccia. 
The shear zone is 3 to 5 feet wide. Its hanging wall is fairly well defined, strikes $\mathrm{N} .15^{\circ}-20^{\circ} \mathrm{W}$., and dips $50^{\circ}-55^{\circ} \mathrm{SW}$. or in places at a steeper angle. The footwall is less continuous and more irregular.
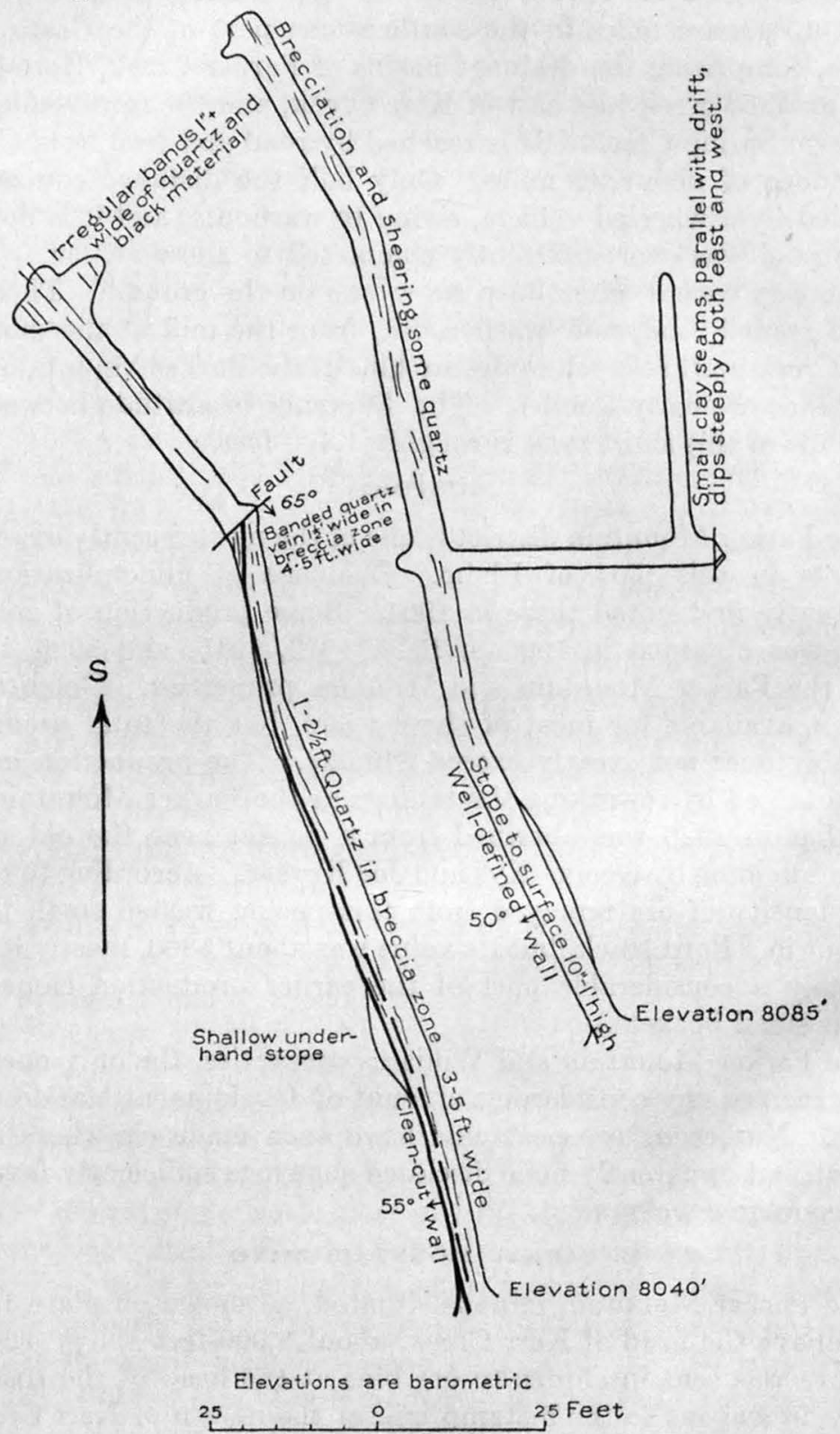

Fraure 5.-Sketch map of the Parker Mountain mine.

In the lower tunnel there is a fairly continuous vein of ribbon-banded quartz in the shear zone. This is from 1 to $2 \frac{1}{2}$ feet wide. It is cut off by a fault about 50 feet from the face, but the rock beyond the 
fault also shows shearing and mineralization. In the upper tunnel the more continuous and better defined part of the vein has been largely stoped out. A crosscut to the east in this tunnel reveals a zone containing numerous small slips in crushed, kaolinized and partly rusted rock. Some are filled with a white hydromica, to widths of a fraction of an inch. This hydromica looks like the clay mineral that is abundant in the Thunder Mountain district, ${ }^{67}$ but it is mineralogically somewhat different. Its precise composition has not been determined.

Cuts on the crest of the ridge at an altitude of about 8,200 feet show that the mineralized zone persists to this point. The pocket of rich ore mined in 1926 was in one of these cuts. There are other small caved openings on the slope containing the two tunnels, indicating that some mineralization occurred outside of the main mineralized zone.

The whole lode, both vein quartz and altered lava, was mined as ore, but probably most of the metal is in the quartz. Umpleby ${ }^{68}$ says that common assay values are reported to have been $\$ 12$ to $\$ 20$ a ton in gold and silver and that the proportions of the two metals vary markedly from place to place. Everywhere the greatest value is in the gold, although the quantity of silver exceeds that of the gold.

The vein quartz is very fine grained. Most of it looks cherty. It is in narrow curved bands, broadly parallel to the strike of the lode but with a tendency to concentric arrangement in places. The finergrained bands are composed of microscopic granular aggregates and local radiating groups in which individual grains are mostly less than 0.1 millimeter in diameter and have obscure boundaries. The coarser bands are composed of elongate quartz grains 0.3 to 1.5 millimeters long, more or less parallel to one another and perpendicular to the sides of the band. Some are in radiating sheaves. Patches of hydromica or sericite are intermixed with the quartz here and there, but their total quantity is small. Umpleby mentions the presence of adularia. None of the ore seen carries more than an exceedingly small amount of metallic minerals. Umpleby mentions a very fine grained metallic mineral of bluish-white color, occurring in blotches and isolated specks. This was not identified but is probably a selenide of silver and gold. Scattered small grains of pyrite, chalcopyrite, and sphalerite are present in some of the ore. Specimens from the rich pockets mined in 1926 and later years contain free gold and a silver mineral containing selenium and sulphur and consequently resembling aguilarite. Both the gold and the selenide appear to be hypogene.

6? Ross, C. P., Thunder Mountain mining district, Valley County, Idaho: Am. Inst. Min. and Met. Eng. Contr. 23, p. 6, February 1933.

65 Umpleby, J. B., Geology ani ore deposits of Lemhi County, Idaho: U.S. Geol. Survey Bull. 528, p. 178, 1913. 
Fluorite was noted in talus on the east side of Warm Spring Creek about $1 \frac{1}{2}$ miles west of the Parker Mountain mine. It was not seen either at that mine or at the Williams property.

\section{WILLIAMS MINE}

The only other property in the district which has received much development is that formerly worked by the two Williams brothers. It is at the head of Kerr Creek about half a mile northeast of the Parker Mountain mine. There are two caved tunnels, one about 8,400 feet above sea level and the other about 100 feet higher. The small amount of ore was formerly packed down to the Parker Mountain mill. It is reported that most of the profit came from the yield of several small pockets of high-grade ore.

\section{MINOR DEPOSITS OF TERTIARY AGE}

In several localities outside of the Parker Mountain district which have as yet received no development there is some evidence of mineralization in either the Challis volcanics or the hornblendic granitic rocks of Miocene age. It is probable that much of the mineralized ground is too low in grade to be of any commercial value, but the available data are summarized below. No sampling was undertaken, so the metallic content is unknown.

\section{MINERALIZATION NEAR HOT CREEK}

On the north side of Warm Spring Creek between Bridge and Hot Creeks there is evidence of some mineralization, mostly in the Challis volcanics near Hot Creek but also extending into rock believed to belong to the Casto volcanics on the west side of the fault that crosses Warm Spring Creek about half a mile below the mouth of Hot Creek. The lava at the mouth of Hot Creek contains sparsely disseminated pyrite cubes but does not otherwise appear to be greatly altered. In the fracture zone on both sides of the fault as mapped on plate 1 there are several small gash veins that contain fluorite and the fine-grained banded quartz characteristic of the deposits of the Parker Mountain district and of similar Tertiary ore deposits in general. The volcanic rocks nearby are bleached and otherwise altered. A few granophyre dikes were mapped here, and several smaller ones also exist.

\section{MINERALIZATION ON HORSE CREEK}

Much of the hornblende granite on the north side of Horse Creek is more or less altered and distinctly rusty. The rock in some outcrops contains so much limonite that it might be considered gossan. Obviously the granite contained, before oxidation, considerable irregularly disseminated pyrite. Residual grains of this mineral are visible in some of the rusty outcrops, and it is probable that unaltered 
pyrite could be found at shallow depths below the surface. The hornblendic granitic rocks wherever exposed are in general more altered than the pink granite, and many outcrops are somewhat rusty, but none of those noted in other localities are as much limonitized as some of those near Horse Creek.

\section{MINERALIZATION NEAR MARBLE CREEK}

On the east side of Marble Creek a short distance above the Mitchell ranch there is a rugged basin carved by a branching group of tributary gulches. Most of the rock here is hornblende granite. Near the head of the basin a group of closely spaced dikes of pink granophyre, shown as a unit on plate 1, interpose between the granitic rock and the Casto volcanics. One of the dikes is highly altered and mineralized at its contact with the granite. It is at an altitude of somewhat more than 7,000 feet in and near the middle of the west boundary of sec. 25, T. 17 N., R. $12 \mathrm{E}$. The porphyry in a cliff over 20 feet high and probably a few hundred feet wide is finely brecciated, silicified, and filled with veinlets containing fine-grained quartz and fluorite. The quartz is the chertlike banded variety common in Tertiary veins. Some of the fluorite is in veinlets an inch or more wide, which have a tendency to comb structure. Some of it is in botryoidal masses of small crystals cementing and surrounding fragments of cherty quartz and silicified porphyry. No metallic minerals were observed, but this by no means indicates that none exist in the deposit. Much of the mineralized rock of the Parker Mountain and similar districts contains no recognizable metallic minerals. No evidence of previous prospecting was observed in this locality. It is believed to be worthy of investigation by anyone interested in the discovery of precious-metal ore deposits of the Tertiary type.

\section{STIBNTTE-BARITE PROSPECT}

Near Meyers Cove several pits have been dug on a mineral deposit differing from any other yet known in the region. The deposit is reported to have been located by Andrew Lee a long time ago. It is on the spur northwest of the mouth of the West Fork of Camas Creek, near the west boundary of sec. 6, T. 17 N., R. 17 E., about 6,000 feet above sea level. A brief description of it has been given in an earlier report. ${ }^{69}$ A little work was done at the prospect in 1927 , but previously it had been untouched for many years. It is doubtful if the deposit will ever prove of much economic value, but its unique character makes it of scientific interest.

The deposit is in light-colored silicic tuff of the Challis volcanics. The tuff was first brecciated and then partly silicified, and the frac-

of Ross, C. P., Ore deposits in Tertiary lava in the Salmon River Mountains, Idaho: Idaho Bur. Mines and Geology Pamphlet 25, p. 17, 1927. 
tures were filled with fine-grained quartz. The quartz and silicified tuff were in turn partly replaced by barite, fluorite, and stibnite. The stibnite in part forms radiating clusters of needlelike crystals, some of which are nearly 2 inches long and much less than a tenth of an inch in diameter. Some of the fine quartz is rhythmically banded, like so much of the similar material in Tertiary ore deposits. in many other regions. Some of this is in alternate light-colored and black bands, less than a tenth of an inch thick. The black bands contain finely divided stibnite, but there is also some other black coloring matter. The fluorite is in the interstices between barite crystals, some of which are more than an inch square. Deposition of barite continued after that of stibnite appears to have ceased. Coarse aggregates of barite have partly replaced masses of stibnite, and crusts of small barite crystals envelop the individual needles composing some of the large clusters of stibnite. There are also fracture planes in the tuff lined with druses of barite, in which needles of stibnite are enclosed and partly replaced by barite crystals. These needles are heterogeneously arranged, and many are not in contact with the fracture walls. They must have crystallized out of the solution after barite began to form but before its deposition was concluded. One of the late steps in the mineralization was the lining of fractures with drusy aggregates of quartz crystals.

The size of the deposit cannot be adequately determined from the small amount of development work that has been done. Probably there are several places where the rock has been more or less brecciated and mineralized. Development at any of these places would probably show that mineralization did not persist far in any given direction. 


\section{INDEX}

A

Abstract of report.

Accessibility of the area

Acknowledgments for aid.

Algonkian and Paleozoic sedimentary rocks,

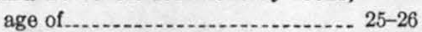

general features of ......................... 21-22

scattered exposures of ................... 28

Algonkian rocks near Yellowjacket........... 15-20

Andesite porphyry, occurrence and character of

Aplite dikes, occurrence and character of..... 41-42

\section{B}

Belt series near Yellowjacket, general features of

Birds, list of ................................. 112

Black Eagle mine, features of ................ 116-117 Boyle ranch, Algonkian and Paleozoic sedimentary rocks, near.

21-26

\section{C}

Camas Creek, partial section of Challis volcanics on.

Casto voleanics, age and correlation of ........ $\quad 35$

andesitic rocks of ......................... 29-30

conglomerate of ............................ 31-32

distribution of ................................. 28-29

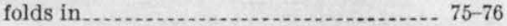

general character of .................... 29

lava and tuff of ........................ 29-31

limestone of ............................ 32

rhyolitic rocks of............................ 30-31

thickness and stratigraphic relations of ... 32-34 topographic expression of ................ 29

Cenozoic time, events of ....................... 96-97

Challis voleanies, age of .................... 53

definition and distribution of ............. 46

general character of ........................... 46-47

minor intrusive rocks related to ......... 54

partial sections of.......................... 49-51

thickness of ............................... 47-52

topographic expression of ................ 46

Cirque lakes, view of, at head of West Fork of Camas Creek...................... pl. 4

Climate.

Columbia mine, features of .................. 112-113

Contact metamorphism, chemical changes in the rocks due to ................... 70-72

general features of......................... 68-69

minerals formed by ........................ 69-70

Continental prospects, features of .......... 115-116

Copper Glance prospect, features of ....... 113-114

Copper-lead-siderite ore, occurrence of, in shear zones
D

Page

Dacite porphyry, occurrence and character of. $62-63$

Deer Creek, prospects near head of.......... 124-125

Diabase, age of .................................. 21

distribution and character of .............. $\quad 20$

Dikes, occurrence and character of............ 41-42

Diorite, age of ............................... 41

distribution and character of.............. $\quad 40$

See also Quartz diorite.

Dolomite marble near Short Creek, occurrence and character of........... $\quad 26$

Drainage.......................................... $5-6$

E

Erosion surface, late Tertiary .......... 84-86, pl. 4 old Tertiary ............................... 83-84

F

Fairchild, J. G., chemical analyses by.... 37, 55, 72 Faulting, occurrence and character of.. 74-75, 77-81 Fauna of the area............................. 9-12 Fish, list of..................................... 12

Flora, lists of ........................ 13-14

Flux quarries, features of ................. 123-124

Folding, occurrence and character of...... 72-73, 77

\section{G}

Geologic history $94-97$

Geologic map and sections of the Casto quadrangle.................. pl. 1 (in pocket)

Geomorphology, summary of ................ 92-94

Glaciation, age of principal ................ 89-90

deposits due to ............................ 90

distribution and extent of ................ $88-89$

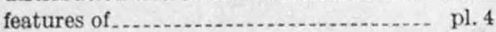

possible older ............................. 90-91

Granite, age and structural relations of ..... $65-67$

analysis of ................................... 55

occurrence and character of ............... $55-57$

porphyries related to . .................... $60-65$

structural relations of .................... 81-83

Granite. See also Hornblende granite.

Granite porphyry, white, occurrence and character of ........................ 61

Granophyre, occurrence and character of .... 64-65

\section{$\mathrm{H}$}

Hoodoo quartzite, character and thickness

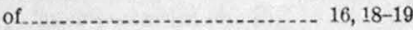

Hornblende granite, occurrence and character of . . .

Hornfels, banded, occurrence and character of ................ 24-25.

Horse Creek, mineralization on........... 130-131 
Hot Creek, mineralization near

Hot springs, character of .................. 105-106

distribution of............................... 105

origin of ................................. 106

use of........................................ 106

\section{I}

Idaho batholith, age of

relation of Miocene granite to ............. $59-60$

rocks related to ............................ $35-45$ structural relations of rocks of . .......... 76

Industries of the area ......................... 8-9

Injection gneiss, character of........ 42-44, pls. 2, 3 definition and distribution of .............. 42 features of ................................. pls. 2, 3 origin of . $44-45$ relation of Miocene granite to ............ 59-60

K

Kersantite, occurrence and character of...... 41,65

\section{L}

Lamprophyre, occurrence and character of... 41, 65 Landslides and slips, features of ........... 92, pl. 5 Lead ore. See Copper-lead-siderite ore.

Limestones, dolomitic, occurrence and character of $23-24$ unaltered and metamorphosed, analyses of

Location of the area............................ 1,4

Lodes, kinds of.................................... 98-99

Loon Creek district, history of............. 117-118 location and extent of $\ldots \ldots \ldots \ldots$ placer deposits in ......................... 118-119

"Lost Cleveland mine", history of ........... 126

Lost Packer mine, development of ........... 119 faulting of lode of ...................... 121-122 general geology of....................... 120-121 geologic maps of location of ................................ 119 ore of oxidation and enrichment in.............. 123

\section{M}

Mammals, list of.

Marble, occurrence and character of

9-10

Marble Creek, mineralization near.......... 131

Merino Creek, partial section of Challis volcanies on.

Mesozoic rocks related to Idaho batholith... 35-45

Mesozoic time, events of ....................... 95-96

Mineral deposits, location of ................... 97-98 with fine ribbon-banded quartz, characteristics of ........................... 101-102 genetic relations of....................... 102 structural features of................... 102

Mining, development of.

Miocene granite, relation of, to Idaho batholith and injection gneiss ......... 59-60

structural relations of ..................... 81-83

Miocene intrusive rocks, occurrence and character of $54-68$

Monte Cristo mine, features of.
Monzonite porphyry, quartz-hornblendebiotite, occurrence and character of ................................. $61-62$

N

Newhouse, W. H., Contact metamorphism_. 68-72 O

Ohio prospect, features of $114-115$

Oligocene volcanics, occurrence and character of ..................... 45-54 Opals, occurrence of ............. 104-105 Overthrusting, occurrence and character of.. 73-74

\section{P}

Paleozoic sedimentary rocks. See Algonkian and Paleozoic sedimentary rocks.

Paleozoic time, events of ..................... 94-95

Parker Mountain district, history of......... 127

location and extent of .................... 127

features of ................................ 127-130

Permian? rocks .............................. 28-35

Placer deposits, occurrence and mining of... 103104, 118-119

Population of the area....................... 7

Porphyries, occurrence and character of...... 61-65

Pre-Cambrian time, events of ................ 94

Purpose of the report........................... 3

Pyroxenite dikes, occurrence and character of. $\quad 41$

\section{Q}

Quartz diorite, character of. 38-39

definition and distribution of ............. $\quad 38$

porphyritic, character of ................. 40 distribution of ........................... 39

Quartz diorites, age of ........................ 40

Quartz-hornblende diorite, occurrence and character of ......................... $58-59$

Quartzite, occurrence and character of ....... $\quad 25$

Quartz monzonite, analysis of ................ $\quad 37$

character of ............................... 36

definition and distribution of ............ 35-36 occurrence and character of .............. 57-58 white, definition and distribution of..... $\quad 37$ relation to Idaho batholith of ........ $37-38$

\section{$\mathrm{R}$}

Ranching, development of ....

Red Jacket prospect, features of $-n_{-2}$


Ridge-crest depressions, features of ....... 91, pl. 5

Salmon River Mountains, position of........ 4 Schist, occurrence and character of ........... 22-23 black, occurrence and character of ........ 27-28 Scope of the report..................... 3

Shear zones, characteristics of genetic relations of ...................... 101 structural features of ....................... 100-101

Short Creek, dolomite marble near.......... 26

Sleeping Deer Mountain, mineralization near 
Page

Stibnite-barite prospect, features of

131-132

Stratigraphy, major features of ............. 14-15

Streams, nomenclature of .................... 6

Structure, features of, in the old rocks....... $72-75$

Supergene processes, effects of ............... 103

$\mathrm{T}$

Terraces and related features of late Tertiary and early Quaternary age.

Tertiary rocks, structure of - $77-83$

Tertiary volcanies, occurrence and character

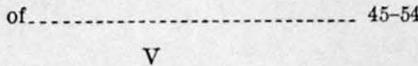

Valentine prospect, features of

W

Williams mine, features of .................. 130

Woodtick Creek, black schist near.
$\mathrm{Y}$

Page

Yankee Fork rhyolite member of Challis volcanics, character of ................. 52-53

definition and distribution of ............ 52

thickness of ............................ 53

Yellowjacket, age of sedimentary rocks near - 19-20 Yellowjacket district, history and production

of . .................................. 107-109

location and extent of ..................... $\quad 107$

Yellowjacket formation, calcareous beds in.. 17-18

character and thickness of ............... 16

quartzitic beds in......................... 17

Yellowjacket mine, bullion produced at.... 100

character of ore of ...................... 111-118

development of ........................ 102

general geology of........................ 119

plan and projection of . .................... pl. 6

structural relations of lode of .......... 110-111 